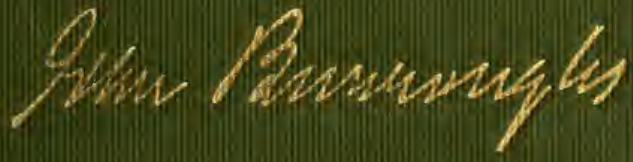




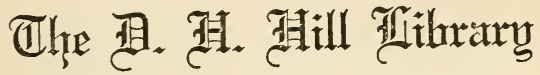

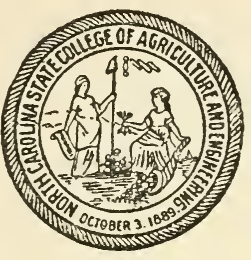

2North Uaralina State Uallege

$$
\begin{aligned}
& \text { QH } 81 \\
& \text { B946 }
\end{aligned}
$$


QH8I

B946

Burroughs

$5290 \%$

Locusts and wild honey

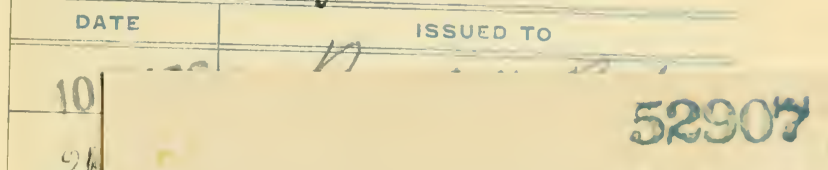

This BOOK may be kept out TWO WEEKS ONLY, and is subject to a fine of FIVE CENTS a day thereafter. It is due on the day indicated below:

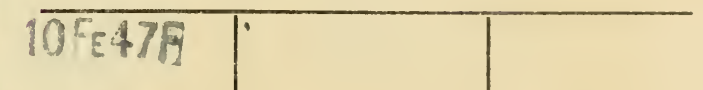

$25 \cdot 147$
$15 \mathrm{Ag}^{\prime} 47 \mathrm{~S}$ 59.48

$20.1 / 1 r+98$

$375 b^{\prime}=0$ 




\section{Banks by Jabn Burraugbs}

WORKS, 23 vols., uniform, $16 \mathrm{mo}$, with frontispiece.

WA KE-RoBIN.

WinTRR SUNSHINK.

Locusts and Wild Hongy.

Fresh Fields.

INDOOR STUDIRS.

Bikds AND Ports, with Other Papers.

Pepacton, and Other Sketches.

Signs and Seasons.

RIVERBY.

WhITMAN: A STUDY.

THB Light OF DAY.

Literary VALUBS.

Far and Near.

WAYS OF NATURB.

Leaf and Tendril.

Time and Changr.

The Summit of the Years.

The Breath of Life.

UNDER THE APPLB-TREBS.

FIBLD AND STUdy.

ACCRPTING THE UNIVBRSE.

UNDER THB MAPLES.

The Last Harvest.

FIELD AND STUDY, Riverside Edition.

UNDER THE APPLE-TREES. Riverside Edition.

THE BREATH OF LIFE. Riverside Edition.

THE SUMMIT OF THE YEARS. Riverside Edition.

TIME AND CHANGE. Riverside Edition.

LEAF AND TENDRIL. Riverside Edition.

WAYS OF NATURE. Riverside Edition.

FAR AND NEAR. Riverside Edition.

LITERARY VALUES. Riverside Edition.

THE LIGHT OF DAY. Riverside Edition.

WHITMAN: A Study. Riverside Edition.

A YEAR IN THE FIELDS. Selections appropriate to each season of the year, from the writings of John Burroughs. Illustrated from Photographs by ClifTON JOHNSON.

IN THE CATSKILLS. Illustrated from Photographs by CLIFTON JOHNSON.

CAMPING AND TRAMPING WITH ROOSEVELT. Illustrated from Photographs.

BIRD AND BOUGH. Poems.

WINTER SUNSHINE. Cambridge Classics Series.

WAKE-ROBIN. Riverside Aldine Series.

SQUIRRELS AND OTHER FUR-BEARERS. Illustrated.

BIRD STORIES FROM BURROUGHS. Illustrated.

HOUGHTON MIFFLIN COMPANY

BOSTON AND NEW YORK 


\title{
LOCUSTS AND WILD HONEY
}

\author{
BY \\ JOHN BURROUGHS
}

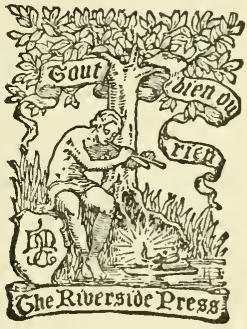

BOSTON AND NEW YORK HOUGHTON MIFFLIN COMPANY fobe fiuergior prege cambrioge 
COPYRIGHT I879, I895, I907 AND I92I BY JOHN BURROUGKS

ALL RIGHTS RESERVED 


\section{PREFACE}

I AM aware that for the most part the title of my book is an allegory rather than an actual description; but readers who have followed me heretofore, I trust, will not be puzzled or misled in the present case by any want of literalness in the matter of the title. If the name carries with it a suggestion of the wild and delectable in nature, of the free and ungarnered harvests which the wilderness everywhere affords to the observing eye and ear, it will prove sufficiently explicit for my purpose.

Esopus-on-Hudson, $\mathbf{N}$. $\mathbf{Y}$. 



\section{CONTENTS}

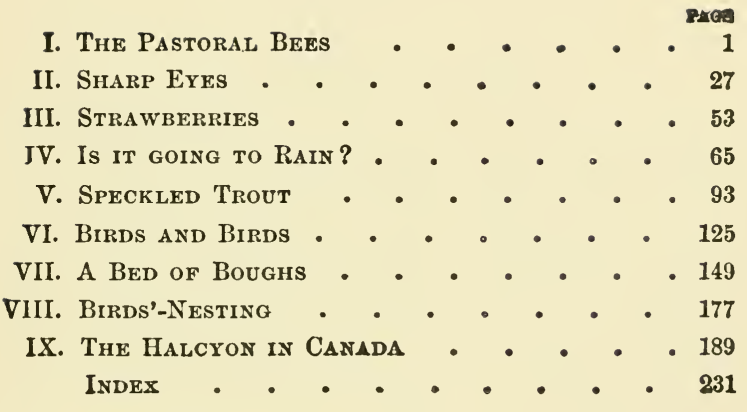





\section{LOCUSTS AND WILD HONEY}

\section{I}

THE PASTORAL BEES

THE honey-bee goes forth from the hive in spring 1 like the dove from Noah's ark, and it is not till after many days that she brings back the olive leaf, which in this case is a pellet of golden pollen upon each hip, usually obtained from the alder or swamp willow. In a country where maple sugar is made the bees get their first taste of sweet from the sap as it flows from the spiles, or as it dries and is condensed upon the sides of the buckets. They will sometimes, in their eagerness, come about the boiling-place and be overwhelmed by the steam and the smoke. But bees appear to be more eager for bread in the spring than for honey: their supply of this article, perhaps, does not keep as well as their stores of the latter; hence fresh bread, in the shape of new pollen, is diligently sought for. My bees get their first supplies from the catkins of the willows. How quickly they find them out! If but one catkin opens anywhere within range, a bee is on 
hand that very hour to rifle it, and it is a most pleasing experience to stand near the hive some mild April day and see them come pouring in with their little baskets packed with this first fruitage of the spring. They will have new bread now; they have been to mill in good earnest; see their dusty coats, and the golden grist they bring home with them.

When a bee brings pollen into the hive he advances to the cell in which it is to be deposited and kicks it off, as one might his overalls or rubber boots, making one foot help the other; then he walks off without ever looking behind him; another bee, one of the indoor hands, comes along and rams it down with his head and packs it into the cell, as the dairymaid packs butter into a firkin with a ladle.

The first spring wild-flowers, whose shy faces among the dry leaves and rocks are so welcome, are rarely frequented by the bee. The anemone, the hepatica, the bloodroot, the arbutus, the numerous violets, the spring beauty, the corydalis, etc., woo all lovers of nature, but seldom woo the honey-lov. ing bee. The arbutus, lying low and keeping green all winter, attains to perfume and honey, but only once have I seen it frequented by bees.

The first honey is perhaps obtained from the flowers of the red maple and the golden willow. The latter sends forth a wild, delicious perfume. The sugar maple blooms a little later, and from its silken tassels a rich nectar is gathered. My bees will not label these different varieties for me, as I really wish they would. Honey from the maple, a tree so clean 
and wholesome, and full of such virtues every way, would be something to put one's tongue to. Or that from the blossoms of the apple, the peach, the cherry, the quince, the currant, - one would like a card of each of these varieties to note their peculiar qualities. The apple-blossom is very important to the bees. A single swarm has been known to gain twenty pounds in weight during its continuance. Bees love the ripened fruit, too, and in August and September will suck themselves tipsy upon varieties like the sops-of-wine.

The interval between the blooming of the fruittrees and that of the clover and raspberry is bridged over in many localities by the honey locust. What a delightful summer murmur these trees send forth at this season! I know nothing about the quality of the honey, but it ought to keep well. But when the red raspberry blooms, the fountains of plenty are unsealed indeed; what a commotion about the hives then, especially in localities where it is extensively cultivated, as in places along the Hudson! The delicate white clover, which begins to bloom about the same time, is neglected; even honey itself is passed by for this modest, colorless, all but odorless flower. A field of these berries in June sends forth a continuous murmur like that of an enormous hive. The honey is not so white as that obtained from clover, but it is easier gathered; it is in shallow cups, while that of the clover is in deep tubes. The bees are up and at it before sunrise, and it takes a brisk shower to drive them in. But the clover blooms later and 
blooms everywhere, and is the staple source of sup. ply of the finest quality of honey. The red clover yields up its stores only to the longer proboscis of the bumblebee, else the bee pasturage of our agricultural districts would be unequaled. I do not know from what the famous honey of Chamouni in the Alps is made, but it can hardly surpass our best products. The snow-white honey of Anatolia in Asiatic Turkey, which is regularly sent to Constantinople for the use of the grand seignior and the ladies of his seraglio, is obtained from the cotton plant, which makes me think that the white clover does not flourish there. The white clover is indigenous with us; its seeds seem latent in the ground, and the application of certain stimulants to the soil, like wood ashes, causes them to germinate and spring up.

The rose, with all its beauty and perfume, yields no honey to the bee, unless the wild species be sought by the bumblebee.

Among the humbler plants let me not forget the dandelion that so early dots the sunny slopes, and upon which the bee languidly grazes, wallowing to his knees in the golden but not over-succulent pasturage. From the blooming rye and wheat the bee gathers pollen, also from the obscure blossoms of Indian corn. Among weeds, catnip is the great favorite. It lasts nearly the whole season and yields richly. It could no doubt be profitably cultivated in some localities, and catnip honey would be a novelty in the market. It would probably partake of the aromatic properties of the plant from which it was derived. 
Among your stores of honey gathered before midsummer you may chance upon a card, or mayhap only a square inch or two of comb, in which the liquid is as transparent as water, of a delicious quality, with a slight flavor of mint. This is the product of the linden or basswood, of all the trees in our forest the one most beloved by the bees. Melissa, the goddess of honey, has placed her seal upon this tree. The wild swarms in the woods frequently reap a choice harvest from it. I have seen a mountain-side thickly studded with it, its straight, tall, smooth, light gray shaft carrying its deep green crown far aloft, like the tulip or maple.

In some of the Northwestern States there are large iorests of it, and the amount of honey reported stored by strong swarms in this section during the time the tree is in bloom is quite incredible. As a shade and ornamental tree the linden is fully equal to the maple, and, if it were as extensively planted and cared for, our supplies of virgin honey would be greatly increased. The famous honey of Lithuania in Russia is the product of the linden.

It is a homely old stanza current among bee folk that
"A swarm of bees in May
Is worth a load of hay;
A swarm of bees in June
Is worth a silver spoon;
But a swarm in July
Is not worth a fly."

A swarm in May is indeed a treasure; it is, like an April baby, sure to thrive, and will very likely 
itself send out a swarm a month or two later: but a swarm in July is not to be despised; it will store no clover or linden honey for the "grand seignior and the ladies of his seraglio," but plenty of the rank and wholesome poor man's nectar, the sun-tanned product of the plebeian buckwheat. Buckwheat honey is the black sheep in this white flock, but there is spirit and character in it. It lays hold of the taste in no equivocal manner, especially when at a winter breakfast it meets its fellow, the russet buckwheat cake. Bread with honey to cover it from the same stalk is double good fortune. It is not black, either, but nut-brown, and belongs to the same class of goods as Herrick's

"Nut-brown mirth and russet wit."

How the bees love it, and they bring the delicious odor of the blooming plant to the hive with them, so that in the moist warm twilight the apiary is redolent with the perfume of buckwheat.

Yet evidently it is not the perfume of any flower that attracts the bees; they pay no attention to the sweet-scented lilac, or to heliotrope, but work upon sumach, silkweed, and the hateful snapdragon. In September they are hard pressed, and do well if they pick up enough sweet to pay the running expenses of their establishment. The purple asters and the goldenrod are about all that remain to them.

Bees will go three or four miles in quest of honey, but it is a great advantage to move the hive near the good pasturage, as has been the custom from the earliest times in the Old World. Some enterprising 
person, taking a hint perhaps from the ancient Egyptians, who had floating apiaries on the Nile, has tried the experiment of floating several hundred colonies north on the Mississippi, starting from New Orleans and following the opening season up, thus realizing a sort of perpetual May or June, the chief attraction being the blossoms of the river willow, which yield honey of rare excellence. Some of the bees were no doubt left behind, but the amount of virgin honey secured must have been very great. In September they should have begun the return trip, following the retreating summer south.

It is the making of the wax that costs with the bee. As with the poet, the form, the receptacle, gives him more trouble than the sweet that fills it, though, to be sure, there is always more or less empty comb in both cases. The honey he can have for the gathering, but the wax he must make himself, - must evolve from his own inner consciousness. When wax is to be made, the wax-makers fill themselves with honey and retire into their chamber for private meditation; it is like some solemn religious rite: they take hold of hands, or hook themselves together in long lines that hang in festoons from the top of the hive, and wait for the miracle to transpire. After about twenty-four hours their patience is rewarded, the honey is turned into wax, minute scales of which are secreted from between the rings of the abdomen of each bee; this is taken off and from it the comb is built up. It is calculated that about twenty-five pounds of honey are used in elaborating 
one pound of comb, to say nothing of the time that is lost. Hence the importance, in an economical point of view, of a recent device by which the honey is extracted and the comb returned intact to the bees. But honey without the comb is the perfume without the rose, - it is sweet merely, and soon degenerates into candy. Half the delectableness is in breaking down these frail and exquisite walls yourself, and tasting the nectar before it has lost its freshness by contact with the air. Then the comb is a sort of shield or foil that prevents the tongue from being overwhelmed by the first shock of the sweet.

The drones have the least enviable time of it. Their foothold in the hive is very presarious. They look like the giants, the lords of the swarm, but they are really the tools. Their loud, threatening hum has no sting to back it up, and their size and noise make them only the more conspicuous marks for the birds. They are all candidates for the favors of the queen, a fatal felicity that is vouchsafed to but one. Fatal, I say, for it is a singular fact in the history of bees that the fecundation of the queen costs the male his life. Yet day after day the drones go forth, threading the mazes of the air in hopes of meeting her whom to meet is death. The queen only leaves the hive once, except when she leads away the swarm, and as she makes no appointment with the male, but wanders here and there, drones enough are provided to meet all the contingencies of the case.

One advantage, at least, results from this system 
of things: there is no incontinence among the males in this republic!

Toward the close of the season, say in July or August, the fiat goes forth that the drones must die; there is no further use for them. Then the poor creatures, how they are huddled and hustled about, trying to hide in corners and byways! There is no loud, defiant humming now, but abject fear seizes them. They cower like hunted criminals. I have seen a dozen or more of them wedge themselves into a small space between the glass and the comb, where the bees could not get hold of them, or where they seemed to be overlooked in the general slaughter. They will also crawl outside and hide under the edges of the hive. But sooner or later they are all zilled or kicked out. The drone makes no resistance, except to pull back and try to get away; but (putting yourself in his place) with one bee a-hold of your collar or the hair of your head, and another a-hold of each arm or leg, and still another feeling for your waistbands with his sting, the odds are greatly against you.

It is a singular fact, also, that the queen is made, not born. If the entire population of Spain or Great Britain were the offspring of one mother, it might be found necessary to hit upon some device by which a royal baby could be manufactured out of an ordinary one, or else give up the fashion of royalty. All the bees in the hive have a common parentage, and the queen and the worker are the same in the egg and in the chick; the patent of royalty 
is in the cell and in the food; the cell being much larger, and the food a peculiar stimulating kind of jelly. In certain contingencies, such as the loss of the queen with no eggs in the royal cells, the workers take the larva of an ordinary bee, enlarge the cell by taking in the two adjoining ones, and nurse it and stuff it and coddle it, till at the end of sixteen days it comes out a queen. But ordinarily, in the natural course of events, the young queen is kept a prisoner in her cell till the old queen has left with the swarm. Later on, the unhatched queen is guarded against the reigning queen, who only wants an opportunity to murder every royal scion in the hive. At this time both the queens, the one a prisoner and the other at large, pipe defiance at each other, a shrill, fine, trumpet-like note that any ear will at once recognize. This challenge, not being allowed to be accepted by either party, is followed, in a day or two, by the abdication of the reigning queen; she leads out the swarm, and her successor is liberated by her keepers, who, in her time, abdicates in favor of the next younger. When the bees have decided that no more swarms can issue, the reigning queen is allowed to use her stiletto upon her unhatched sisters. Cases have been known where two queens issued at the same time, when a mortal combat ensued, encouraged by the workers, who formed a ring about them, but showed no preference, and recognized the victor as the lawful sovereign. For these and many other curious facts we are indebted to the blind Huber. 
It is worthy of note that the position of the queen cells is always vertical, while that of the drones and workers is horizontal; majesty stands on its head, which fact may be a part of the secret.

The notion has always very generally prevailed that the queen of the bees is an absolute ruler, and issues her royal orders to willing subjects. Hence Napoleon the First sprinkled the symbolic bees over the imperial mantle that bore the arms of his dynasty; and in the country of the Pharaohs the bee was used as the emblem of a people sweetly submissive to the orders of its king. But the fact is, a swarm of bees is an absolute democracy, and kings and despots can find no warrant in their example. The power and authority are entirely vested in the great mass, the workers. They furnish all the brains and foresight of the colony, and administer its affairs. Their word is law, and both king and queen must obey. They regulate the swarming, and give the signal for the swarm to issue from the hive; they select and make ready the tree in the woods and conduct the queen to it.

The peculiar office and sacredness of the queen consists in the fact that she is the mother of the swarm, and the bees love and cherish her as a mother and not as a sovereign. She is the sole female bee in the hive, and the swarm clings to her because she is their life. Deprived of their queen, and of all brood from which to rear one, the swarm loses all heart and soon dies, though there be an abundance of honey in the hive. 
The common bees will never use their sting upon the queen; if she is to be disposed of, they starve her to death; and the queen herself will sting nothing but royalty, - nothing but a rival queen.

The queen, I say, is the mother bee; it is undoubtedly complimenting her to call her a queen and invest her with regal authority, yet she is a superb creature, and looks every inch a queen. It is an event to distinguish her amid the mass of bees when the swarm alights; it awakens a thrill. Before you have seen a queen, you wonder if this or that bee, which seems a little larger than its fellows, is not she, but when you once really set eyes upon her you do not doubt for a moment. You know that is the queen. That long, elegant, shining, feminine-looking creature can be none less than royalty. How beautifully her body tapers, how distinguished she looks, how deliberate her movements! The bees do not fall down before her, but caress her and touch her person. The drones, or males, are large bees, too, but coarse, blunt, broad-shouldered, masculinelooking. There is but one fact or incident in the life of the queen that looks imperial and authoritative: Huber relates that when the old queen is restrained in her movements by the workers, and prevented from destroying the young queens in their cells, she assumes a peculiar attitude and utters a note that strikes every bee motionless and makes every head bow; while this sound lasts, not a bee stirs, but all look abashed and humbled: yet whether the emotion is one of fear, or reverence, or of "sym- 
pathy with the distress of the queen mother, is hard to determine. The moment it ceases and she advances again toward the royal cells, the bees bite and pull and insult her as before.

I always feel that I have missed some good fortune if I am away from home when my bees swarm. What a delightful summer sound it is! how they come pouring out of the hive, twenty or thirty thousand bees, each striving to get out first? It is as wher the dam gives way and lets the waters loose; it is a flood of bees which breaks upward into the air, and becomes a maze of whirling black lines to the eye, and a soft chorus of myriad musical sounds to the ear. This way and that way they drift, now contracting, now expanding, rising, sinking, growing thick about some branch or bush, then dispersing and massing at some other point, till finally they begin to alight in earnest, when in a few moments the whole swarm is collected upon the branch, forming a bunch perhaps as large as a two-gallon measure. Here they will hang from one to three or four hours or until a suitable tree in the woods is looked up, when, if they have not been offered a hive in the mean time, they are up and off. In hiving them, if any accident happens to the queen the enterprise miscarries at once. One day I shook a swarm from a small pear-tree into a tin pan, set the pan down on a shawl spread beneath the tree, and put the hive over it. The bees presently all crawled up into it, and all seemed to go well for ten or fifteen minutes, when I observed that something was wrong; 
the bees began to buzz excitedly and to rush about in a bewildered manner, then they took to the wing and all returned to the parent stock. On lifting up the pan, I found beneath it the queen with three or four other bees. She had been one of the first to fall, had missed the pan in her descent, and I had set it upon her. I conveyed her tenderly back to the hive, but either the accident terminated fatally with her, or else the young queen had been liberated in the interim, and one of them had fallen in combat, for it was ten days before the swarm issued a second time.

No one, to my knowledge, has ever seen the bees house-hunting in the woods. Yet there can be no doubt that they look up new quarters either before or on the day the swarm issues. For all bees are wild bees and incapable of domestication; that is, the instinct to go back to nature and take up again their wild abodes in the trees is never eradicated. Years upon years of life in the apiary seem to have no appreciable effect towards their final, permanent domestication. That every new swarm contemplates migrating to the woods, seems confirmed by the fact that they will only come out when the weather is favorable to such an enterprise, and that a passing cloud, or a sudden wind, after the bees are in the air, will usually drive them back into the parent hive. Or an attack upon them with sand or gravel, or loose earth or water, will quickly cause them to change their plans. I would not even say but that, when the bees are going off, the apparently absurd 
practice, now entirely discredited by regular beekeepers but still resorted to by unscientific folk, of beating upon tin pans, blowing horns, and creating an uproar generally, might not be without good results. Certainly not by drowning the "orders" of the queen, but by impressing the bees, as with some unusual commotion in nature. Bees are easily alarmed and disconcerted, and I have known runaway swarms to be brought down by a farmer plowing in the field who showered them with handfuls of loose soil.

I love to see a swarm go off - if it is not mine, and, if mine must go, I want to be on hand to see the fun. It is a return to first principles again by a very direct route. The past season I witnessed two such escapes. One swarm had come out the day before, and, without alighting, had returned to the parent hive, - some hitch in the plan, perhaps, or may be the queen had found her wings too weak. The next day they came out again and were hived. But something offended them, or else the tree in the woods - perhaps some royal old maple or birch, holding its head high above all others, with snug, spacious, irregular chambers and galleries - had too many attractions; for they were presently discovered filling the air over the garden, and whirling excitedly around. Gradually they began to drift over the street; a moment more, and they had become separated from the other bees, and, drawing together in a more compact mass or cloud, away they went, a humming, flying vortex of bees, the queen in the 
centre, and the swarm revolving around her as a pivot, - over meadows, across creeks and swamps, straight for the heart of the mountain, about a mile distant, - slow at first, so that the youth who gave chase kept up with them, but increasing their speed till only a foxhound could have kept them in sight. I saw their pursuer laboring up the side of the mountain; saw his white shirtsleeves gleam as he entered the woods; but he returned a few hours afterward without any clew as to the particular tree in which they had taken refuge out of the ten thousand that covered the side of the mountain.

The other swarm came out about one o'clock of a hot July day, and at once showed symptoms that alarmed the keeper, who, however, threw neither dirt nor water. The house was situated on a steep side-hill. Behind it the ground rose, for a hundred rods or so, at an angle of nearly forty-five degrees, and the prospect of having to chase them up this hill, if chase them we should, promised a good trial of wind at least; for it soon became evident that their course lay in this direction. Determined to have a hand, or rather a foot, in the chase, I threw off my coat and hurried on, before the swarm was yet fairly organized and under way. The route soon led me into a field of standing rye, every spear of which held its head above my own. Plunging recklessly forward, my course marked to those watching from below by the agitated and wriggling grain, I emerged from the miniature forest just in time to see the runaways disappearing over the top of the hill, 
some fifty rods in advance of me. Lining them as well as I could, I soon reached the hilltop, my breath utterly gone and the perspiration streaming from every pore of my skin. On the other side the country opened deep and wide. A large valley swept around to the north, heavily wooded at its head and on its sides. It became evident at once that the bees had made good their escape, and that whether they had stopped on one side of the valley or the other, or had indeed cleared the opposite mountain and gone into some unknown forest beyond, was entirely problematical. I turned back, therefore, thinking of the honey-laden tree that some of these forests would hold before the falling of the leaf.

I heard of a youth in the neighborhood move lucky than myself on a like occasion. It seems that he had got well in advance of the swarm, whose route lay over a hill, as in my case, and as he neared the summit, hat in hand, the bees had just come up and were all about him. Presently he noticed them hovering about his straw hat, and alighting on his arm; and in almost as brief a time as it takes to relate it, the whole swarm had followed the queen into his hat. Being near a stone wall, he coolly deposited his prize upon it, quickly disengaged himself from the accommodating bees, and returned for a hive. The explanation of this singular circumstance no doubt is, that the queen, unused to such long and heavy flights, was obliged to alight from very exhaustion. It is not very unusual for swarms to be thus found in remote fields, collected upon a bush or branch of a tree. 
When a swarm migrates to the woods in this manner, the individual bees, as I have intimated, do not move in right lines or straight forward, like a flock of birds, but round and round, like chaff in a whirlwind. Unitedly they form a humming, revolving, nebulous mass, ten or fifteen feet across, which keeps just high enough to clear all obstacles, except in crossing deep valleys, when, of course, it may be very high. The swarm seems to be guided by a line of couriers, which may be seen (at least at the outset) constantly going and coming. As they take a direct course, there is always some chance of following them to the tree, unless they go a long distance, and some obstruction, like a wood or a swamp or a high hill, intervenes, - enough chance, at any rate, to stimulate the lookers-on to give vigorous chase as long as their wind holds out. If the bees are successfully followed to their retreat, two plans are feasible, - either to fell the tree at once, and seek to hive them, perhaps bring them home in the section of the tree that contains the cavity; or to leave the tree till fall, then invite your neighbors and go and cut it, and see the ground flow with honey. The former course is more business-like; but the latter is the one usually recommended by one's friends and neighbors.

Perhaps nearly one third of all the runaway swarms leave when no one is about, and hence are unseen and unheard, save, perchance, by some distant laborers in the field, or by some youth plowing on the side of the mountain, who hears an unusual 
humming noise, and sees the swarm dimly whirling by overhead, and, maybe, gives chase; or he may simply catch the sound, when he pauses, looks quickly around, but sees nothing. When he comes in at night he tells how he heard or saw a swarm of bees go over; and perhaps from beneath one of the hives in the garden a black mass of bees has disappeared during the day.

They are not partial as to the kind of tree, pine, hemlock, elm, birch, maple, hickory, - any tree with a good cavity high up or low down. A swarm of mine ran away from the new patent hive I gave them, and took up their quarters in the hollow trunk of an old apple-tree across an adjoining field. The entrance was a mouse-hole near the ground.

Another swarm in the neighborhood deserted their keeper, and went into the cornice of an outhouse that stood amid evergreens in the rear of a large mansion. But there is no accounting for the taste of bees, as Samson found when he discovered the swarm in the carcass, or more probably the skeleton, of the lion he had slain.

In any given locality, especially in the more wooded and mountainous districts, the number of swarms that thus assert their independence forms quite a large per cent. In the Northern States these swarms very often perish before spring; but in such a country as Florida they seem to multiply, till bee-trees are very common. In the West, also, wild honey is often gathered in large quantities. I 
noticed, not long since, that some wood-choppers on the west slope of the Coast Range felled a tree that had several pailfuls in it.

One night on the Potomac a party of us unwittingly made our camp near the foot of a bee-tree, which next day the winds of heaven blew down, for our special delectation, at least so we read the sign. Another time, while sitting by a waterfall in the leafless April woods, I discovered a swarm in the top of a large hickory. I had the season before remarked the tree as a likely place for bees, but the screen of leaves concealed them from me. This time my former presentiment occurred to me, and, looking sharply, sure enough there were the bees, going out and in a large, irregular opening. In June a violent tempest of wind and rain demolished the tree, and the honey was all lost in the creek into which it fell. I happened along that way two or three days after the tornado, when I saw a remnant of the swarm, those, doubtless, that escaped the flood and those that were away, when the disaster came, hanging in a small black mass to a branch high up near where their home used to be. They looked forlorn enough. If the queen was saved, the remnant probably sought another tree; otherwise the bees soon died.

I have seen bees desert their hive in the spring when it was infested with worms, or when the honey was exhausted; at such times the swarm seems to wander aimlessly, alighting here and there, and perhaps in the end uniting with some other colony. In 
ease of such union, it would be curious to know if negotiations were first opened between the parties, and if the houseless bees are admitted at once to all the rights and franchises of their benefactors. It would be very like the bees to have some preliminary plan and understanding about the matter on both sides.

Bees will accommodate themselves to almost any quarters, yet no hive seems to please them so well as a section of a hollow tree, - "gums," as they are called in the South and West where the sweet gum grows. In some European countries the hive is always made from the trunk of a tree, a suitable cavity being formed by boring. The old-fashioned straw hive is picturesque, and a great favorite with the bees also.

The life of a swarm of bees is like an active and hazardous campaign of an army; the ranks are being continually depleted, and continually recruited. What adventures they have by flood and field, and what hair-breadth escapes! A strong swarm during the honey season loses, on an average, about four or five thousand per month, or one hundred and fifty per day. They are overwhelmed by wind and rain, caught by spiders, benumbed by cold, crushed by cattle, drowned in rivers and ponds, and in many nameless ways cut off or disabled. In the spring the principal mortality is from the cold. As the sun declines they get chilled before they can reach home. Many fall down outside the hive, unable to get in with their burden. One may see them come utterly 
spent and drop hopelessly into the grass in front of their very doors. Before they can rest the cold has stiffened them. I go out in April and May and pick them up by the handfuls, their baskets loaded with pollen, and warm them in the sun or in the house, or by the simple warmth of my hand, until they cars crawl into the hive. Heat is their life, and an ap. parently lifeless bee may be revived by warming him. I have also picked them up while rowing on the river and seen them safely to shore. It is amusing to see them come hurrying home when there is a thunder-storm approaching. They come piling in till the rain is upon them. Those that are overtaken by the storm doubtless weather it as best they can in the sheltering trees or grass. It is not probable that a bee ever gets lost by wandering into strange and unknown parts. With their myriad eyes they see everything; and then their sense of locality is very acute, is, indeed, one of their ruling traits. When a bee marks the place of his hive, or of a bit of good pasturage in the fields or swamps, or of the beehunter's box of honey on the hills or in the woods, he returns to it as unerringly as fate.

Honey was a much more important article of food with the ancients than it is with us. As they appear to have been unacquainted with sugar, honey, no doubt, stood them instead. It is too rank and pungent for the modern taste; it soon cloys upon the palate. It demands the appetite of youth, and the strong, robust digestion of people who live much in the open air. It is a more wholesome food than 
sugar, and modern confectionery is poison beside it. Beside grape sugar, honey contains manna, mucilage, pollen, acid, and other vegetable odoriferous substances and juices. It is a sugar with a kind of wild natural bread added. The manna of itself is both food and medicine, and the pungent vegetable extracts have rare virtues. Honey promotes the excretions, and dissolves the glutinous and starchy impedimenta of the system.

Hence it is not without reason that with the ancients a land flowing with milk and honey should mean a land abounding in all good things; and the queen in the nursery rhyme, who lingered in the kitchen to eat "bread and honey" while the "king was in the parlor counting out his money," was doing a very sensible thing. Epaminondas is said to have rarely eaten anything but bread and honey. The Emperor Augustus one day inquired of a centenarian how he had kept his vigor of mind and body so long; to which the veteran replied that it was by "oil without and honey within." Cicero, in his "Old Age," classes honey with meat and milk and cheese as among the staple articles with which a well-kept farmhouse will be supplied.

Italy and Greece, in fact all the Mediterranean countries, appear to have been famous lands for honey. Mount Hymettus, Mount Hybla, and Mount Ida produced what may be called the classic honey of antiquity, an article doubtless in no wise superior to our best products. Leigh Hunt's "Jar of Honey" is mainly distilled from Sicilian history and literature, 
Theocritus furnishing the best yield. Sicily has always been rich in bees. Swinburne (the traveler of a hundred years ago) says the woods on this island abounded in wild honey, and that the people also had many hives near their houses. The idyls of Theocritus are native to the island in this respect, and abound in bees - "flat-nosed bees," as he calls them in the Seventh Idyl - and comparisons in which comb-honey is the standard of the most delectable of this world's goods. His goatherds can think of no greater bliss than that the mouth be filled with honeyccmbs, or to be inclosed in a chest like Daphnis and fed on the combs of bees; and among the delectables with which Arsinoë cherishes Adonis are "honeycakes," and other tidbits made of "sweet honey." In the country of Theocritus this custom is said still to prevail: when a couple are married, the attendants place honey in their mouths, by which they would symbolize the hope that their love may be as sweet to their souls as honey to the palate.

It was fabled that Homer was suckled by a priestess whose breasts distilled honey; and that once, when Pindar lay asleep, the bees dropped honey upon his lips. In the Old Testament the food of the promised Immanuel was to be butter and honey (there is much doubt about the butter in the original), that he might know good from evil; and Jonathan's eyes were enlightened by partaking of some wood or wild honey: "See, I pray you, how mine eyes have been enlightened, because I tasted a little of this honey." So far as this part of his diet was concerned, therefore. 
John the Baptist, during his sojourn in the wilderness, his divinity-school days in the mountains and plains of Judea, fared extremely well. About the other part, the locusts, or, not to put too fine a point on it, the grasshoppers, as much cannot be waid, though they were among the creeping and leaping things the children of Israel were permitted to eat. They were probably not eaten raw, but roasted in that most primitive of ovens, a hole in the ground made hot by building a fire in it. The locusts and honey may have been served together, as the Bedas of Ceylon are said to season their meat with honey. At any rate, as the locust is often a great plague in Palestine, the prophet in eating them found his account in the general weal, and in the profit of the pastoral bees; the fewer locusts, the more flowers. Owing to its numerous wild-flowers and flowering shrubs, Palestine has always been a famous country for bees. They deposit their honey in hollow trees, as our bees do when they escape from the hive, and in holes in the rocks, as our's do not. In a tropical or semitropical climate, bees are quite apt to take refuge in the rocks; but where ice and snow prevail, as with us, they are much safer high up in the trunk of a forest tree.

The best honey is the product of the milder parts of the temperate zone. There are too many rank and poisonous plants in the tropics. Honey from certain districts of Turkey produces headache and vomiting, and that from Brazil is used chiefly as medicine. The honey of Mount Hymettus owes its 
fine quality to wild thyme. The best honey in Persia and in Florida is collected from the orange blossom. The celebrated honey of Narbonne in the south of France is obtained from a species of rosemary. In Scotland good honey is made from the blossoming heather.

California honey is white and delicate and highly perfumed, and now takes the lead in the market. But honey is honey the world over; and the bee is the bee still. "Men may degenerate," says an old traveler, "may forget the arts by which they acquired renown; manufactures may fail, and commodities be debased; but the sweets of the wildflowers of the wilderness, the industry and natural mechanics of the bee, will continue without change or derogation." 


\section{II}

\section{SHARP EYES}

WOTING how one eye seconds and reinforces the other, I have often amused myself by wondering what the effect would be if one could go on opening eye after eye to the number say of a dozen or more. What would he see? Perhaps not the invisible, - not the odors of flowers or the fever germs in the air, - not the infinitely small of the microscope or the infinitely distant of the telescope. This would require, not more eyes so much as an eye constructed with more and different lenses; but would he not see with augmented power within the natural limits of vision? At any rate, some persons seem to have opened more eyes than others, they see with such force and distinctness; their vision penetrates the tangle and obscurity where that of others fails like a spent or impotent bullet. How many eyes did Gilbert White open? how many did Henry Thureau? how many did Audubon? how many does the hunter, matching his sight against the keen and alert sense of a deer or a moose, or fox or a wolf? Not outward eyes, but inward. We open another eye whenever we see beyond the first general features or outlines of things, - whenever we grasp 
the special details and characteristic markings that this mask covers. Science confers new powers of vision. Whenever you have learned to discriminate the birds, or the plants, or the geological features of a country, it is as if new and keener eyes were added.

Of course one must not only see sharply, but read aright what he sees. The facts in the life of Nature that are transpiring about us are like written words that the observer is to arrange into sentences. Or the writing is in cipher and he must furnish the key. A female oriole was one day observed very much preoccupied under a shed where the refuse from the horse stable was thrown. She hopped about among the barn fowls, scolding them sharply when they came too near her. The stable, dark and cavernous, was just beyond. The bird, not finding what she wanted outside, boldly ventured into the stable, and was presently captured by the farmer. What did she want? was the query. What but a horsehair for her nest which was in an apple-tree near by? and she was so bent on having one that I have no doubt she would have tweaked one out of the horse's tail had he been in the stable. Later in the season I examined her nest, and found it sewed through and through with several long horsehairs, so that the bird persisted in her search till the hair was found.

Little dramas and tragedies and comedies, little characteristic scenes, are always being enacted in the lives of the birds, if our eyes are sharp enough to see them. Some clever observer saw this little comedy played among some English sparrows, and wrote 
an account of it in his newspaper; it is too good not to be true: A male bird brought to his box a large, fine goose feather, which is a great find for a sparrow and much coveted. After he had deposited his prize and chattered his gratulations over it, he went away in quest of his mate. His next-door neighbor, a female bird, seeing her chance, quickly slipped in and seized the feather; and here the wit of the bird came out, for instead of carrying it into her own box she flew with it to a near tree and hid it in a fork of the branches, then went home, and when her neighbor returned with his mate was innocently employed about her own affairs. The proud male, finding his feather gone, came out of his box in a high state of excitement, and, with wrath in his manner and accusation on his tongue, rushed into the cote of the female. Not finding his goods and chattels there as he had expected, he stormed around a while, abusing everybody in general and his neighbor in particular, and then went away as if to repair the loss. As soon as he was out of sight, the shrewd thief went and brought the feather home and lined her own domicile with it.

I was much amused one summer day in seeing a bluebird feeding her young one in the shaded street of a large town. She had captured a cicada or harvest-fly, and, after bruising it a while on the ground, flew with it to a tree and placed it in the beak of the young bird. It was a large morsel, and the nother seemed to have doubts of her chick's ability to dispose of it, for she stood near and watched its 
efforts with great solicitude. The young bird struggled valiantly with the cicada, but made no headway in swallowing it, when the mother took it from him and flew to the sidewalk, and proceeded to break and bruise it more thoroughly. Then she again placed it in his beak, and seemed to say, "There, try it now," and sympathized so thoroughly with his efforts that she repeated many of his motions and contortions. But the great fly was unyielding, and, indeed, seemed ridiculously disproportioned to the beak that held it. The young bird fluttered and fluttered, and screamed, "I'm stuck, I'm stuck!" till the anxious parent again seized the morsel and carried it to an iron railing, where she came down upon it for the space of a minute with all the force and momentum her beak could command. Then she offered it to her young a third time, but with the same result as before, except that this time the bird dropped it; but she reached the ground as soon as the cicada did, and taking it in her beak flew some distance to a high board fence, where she sat motionless for some moments. While pondering the problem how that fly should be broken, the male bluebird approached her, and said very plainly, and I thought rather curtly, "Give me that bug," but she quickly resented his interference and flew farther away, where she sat apparently quite discouraged when I last saw her.

The bluebird is a home bird, and I am never tired of recurring to him. His coming or reappearance in the spring marks a new chapter in the progress of the season; things are never quite the same after sno 
has heard that note. The past spring the males came about a week in advance of the females. $\Lambda$ fine male lingered about my grounds and orchard all that time, apparently waiting the arrival of his mate. $\mathrm{He}$ called and warbled every day, as if he felt sure she was within ear-shot and could be hurried up. Now he warbled half-angrily or upbraidingly, then coaxingly, then cheerily and confidently, the next moment in a plaintive, far-away manner. He would half open his wings, and twinkle them caressingly, as if beckoning his mate to his heart. One morning she had come, but was shy and reserved. The fond male flew to a knothole in an old apple-tree, and coaxed her to his side. I heard a fine confidential warble, - the old, old story. But the female flew to a near tree, and uttered her plaintive, homesick note. The male went and got some dry grass or bark in his beak, and flew again to the hole in the old tree, and promised unremitting devotion, but the other said, "Nay," and flew away in the distance. When he saw her going, or rather heard her distant note, he dropped his stuff, and cried out in a tone that said plainly enough, "Wait a minute. One word, please," and flew swiftly in pursuit. He won her before long, however, and early in April the pair were established in one of the four or five boxes I had put up for them, but not until they had changed their minds several times. As soon as the first brood had flown, and while they were yet under their parents' care, they began another nest in one of the other boxes, the female, as usual, doing all 
the work, and the male all the complimenting. A source of occasional great distress to the mother bird was a white cat that sometimes followed me about. The cat had never been known to catch a bird, but she had a way of watching them that was very embarrassing to the bird. Whenever she appeared, the mother bluebird would set up that pitiful melodious plaint. One morning the cat was standing by me, when the bird came with her beak loaded with building material, and alighter above me to survey the place before going into the box. When she saw the cat she was greatly disturbed, and in her agitation could not keep her hold upon all her material. Straw after straw came eddying down, till not half her original burden remained. After the cat had gone away the bird's alarm subsided, till presently, seeing the coast clear, she flew quickly to the box and pitched in her remaining straws with the greatest precipitation, and, without going in to arrange them, as was her wont, flew away in evident relief.

In the cavity of an apple-tree but a few yards off, and much nearer the house than they usually build, a pair of high-holes, or golden-shafted woodpeckers, took up their abode. A knothole which led to the decayed interior was enlarged, the live wood being cut away as clean as a squirrel would have done it. The inside preparations I could not witness, but day after day, as I passed near, I heard the bird hammering away, evidently beating down obstructions and rhaping and enlarging the cavity. The chips were not brought out, but were used rather to floor the 
interior. The woodpeckers are not nest-builders, but rather nest-carvers.

The time seemed very short before the voices of the young were heard in the heart of the old tree, - at first feebly, but waxing stronger day by day until they could be heard many rods distant. When I put my hand upon the trunk of the tree, they would set up an eager, expectant chattering; but if I climbed up it toward the opening, they soon detected the unusual sound and would hush quickly, only now and then uttering a warning note. Long before they were fully fledged they clambered up to the orifice to receive their food. As but one could stand in the opening at a time, there was a good deal of elbowing and struggling for this position. It was a very desirable one aside from the advantages it had when food was served; it looked out upon the great, shining world, into which the young birds seemed never tired of gazing. The fresh air must have been a consideration also, for the interior of a high-hole's dwelling is not sweet. When the parent birds came with food, the young one in the opening did not get it all, but after he had received a portion, either on his own motion or on a hint from the old one, he would give place to the one behind him. Still, one bird evidently outstripped his fellows, and in the race of life was two or three days in advance of them. His voice was loudest and his head oftenest at the window. But I noticed that, when he had kept the position too long, the others evidently made it uncomfortable in his rear, and, after "fidgeting" about 
a while, he would be compelled to "back down." But retaliation was then easy, and I fear his mates spent few easy moments at that lookout. They would close their eyes and slide back into the cavity as if the world had suddenly lost all its charms for them.

This bird was, of course, the first to leave the nest. For two days before that event he kept his position in the opening most of the time and sent forth his strong voice incessantly. The old ones abstained from feeding him almost entirely, no doubt to encourage his exit. As I stood looking at him one afternoon and noting his progress, he suddenly reached a resolution, - seconded, I have no doubt, from the rear, - and launched forth upon his untried wings. They served him well, and carried him about fifty yards up-hill the first heat. The second day after, the next in size and spirit left in the same manner; then another, till only one remained. The parent birds ceased their visits to him, and for one day he called and called till our ears were tired of the sound. His was the faintest heart of all. Then he had none to encourage him from behind. $\mathrm{He}$ left the nest and clung to the outer bole of the tree, and yelped and piped for an hour longer; then he committed himself to his wings and went his way like the rest.

A young farmer in the western part of New York, who has a sharp, discriminating eye, sends me some interesting notes about a tame high-hole he once had. "Did you ever notice," says he, "that the high- 
hole never eats anything that he cannot pick up with his tongue? At least this was the case with a young one I took from the nest and tamed. He could thrust out his tongue two or three inches, and it was amusing to see his efforts to eat currants from the hand. He would run out his tongue and try to stick it to the currant; failing in that, he would bend his tongue around it like a hook and try to raise it by a sudden jerk. But he never succeeded, the round fruit would roll and slip away every time. He never seemed to think of taking it in his beak. His tongue was in constant use to find out the nature of everything he saw; a nail-hole in a board or any similar hole was carefully explored. If he was held near the face he would soon be attracted by the eye and thrust his tongue into it. In this way he gained the respect of a number of half-grown cats that were around the house. I wished to make them familiar to each other, so there would be less danger of their killing him. So I would take them both on my knee, when the bird would soon notice the kitten's eyes, and, leveling his bill as carefully as a marksman levels his rifle, he would remain so a minute, when he would dart his tongue into the cat's eye. This was held by the cats to be very mysterious: being struck in the eye by something invisible to them. They soon acquired such a terror of him that they would avoid him and run away whenever they saw his bill turned in their direction. $\mathrm{He}$ never would swallow a grasshopper even when it was placed in his throat; he would shake himself until 
he had thrown it out of his mouth. His 'best hold' was ants. He never was surprised at anything, and never was afraid of anything. He would drive the turkey gobbler and the rooster. He would advance upon them holding one wing up as high as possible, as if to strike with it, and shuffle along the ground toward them, scolding all the while in a harsh voice. I feared at first that they might kill him, but I soon found that he was able to take care of himself. I would turn over stones and dig into ant-hills for him, and he would lick up the ants so fast that a stream of them seemed going into his mouth unceasingly. I kept him till late in the fall, when he disappeared, probably going south, and I never saw him again."

My correspondent also sends me some interesting observations about the cuckoo. He says a large gooseberry-bush standing in the border of an old hedge-row, in the midst of open fields, and not far from his house, was occupied by a pair of cuckoos for two seasons in succession, and, after an interval of a year, for two seasons more. This gave him a good chance to observe them. He says the mother bird lays a single egg, and sits upon it a number of days before laying the second, so that he has seen one young bird nearly grown, a second just hatched, and a whole egg all in the nest at once. "So far as I have seen, this is the settled practice, - the young leaving the nest one at a time to the number of six or eight. The young have quite the look of the young of the dove in many respects. When nearly grown they are covered with long blue pin. 
feathers as long as darning-needles, without a bit of plumage on them. They part on the back and hang down on each side by their own weight. With its curious feathers and misshapen body, the young birc is anything but handsome. They never open their mouths when approached, as many young birds do, but sit perfectly still, hardly moving when touched." $\mathrm{He}$ also notes the unnatural indifference of the mother bird when her nest and young are approached. She makes no sound, but sits quietly on a near branch in apparent perfect unconcern.

These observations, together with the fact that the egg of the cuckoo is occasionally found in the nests of other birds, raise the inquiry whether our bird is slowly relapsing into the habit of the European species, which always foists its egg upon other birds; or whether, on the other hand, it be not mending its manners in this respect. It has but little to unlearn or forget in the one case, but great progress to make in the other. How far is its rudimentary nest-a mere platform of coarse twigs and dry stalks of weeds - from the deep, compact, finely woven and finely modeled nest of the goldfinch or the kingbird, and what a gulf between its indifference toward its young and their solicitude! Its irregular manner of laying also seems better suited to a parasite like our cowbird, or the European cuckoo, than to a regular nest-builder.

This observer, like most sharp-eyed persons, sees plenty of interesting things as he goes about his work. He one day saw a white swallow, which is 
of rare occurrence. He saw a bird, a sparrow he thinks, fly against the side of a horse and fill his beak with hair from the loosened coat of the animal. $\mathrm{He}$ saw a shrike pursue a chickadee, when the latter escaped by taking refuge in a small hole in a tree. One day in early spring he saw two hen-hawks, that were circling and screaming high in air, approach each other, extend a claw, and, clasping them together, fall toward the earth, flapping and struggling as if they were tied together; on nearing the ground they separated and soared aloft again. He supposed that it was not a passage of war but of love, and that the hawks were toying fondly with each other.

$\mathrm{He}$ further relates a curious circumstance of finding a hummingbird in the upper part of a barn with its bill stuck fast in a crack of one of the large timbers, dead, of course, with wings extended, and as dry as a chip. The bird seems to have died, as it had lived, on the wing, and its last act was indeed a ghastly parody of its living career. Fancy this nimble, flashing sprite, whose life was passed probing the honeyed depths of flowers, at last thrusting its bill into a crack in a dry timber in a hay-loft, and, with spread wings, ending its existence!

When the air is damp and heavy, swallows frequently hawk for insects about cattle and moving herds in the field. My farmer describes how they attended him one foggy day, as he was mowing in the meadow with a mowing-machine. It had been foggy for two days, and the swallows were very hungry, and the insects stupid and inert. When the 
sound of his machine was heard, the swallows appeared and attended him like a brood of hungry chickens. He says there was a continued rush of purple wings over the "cut-bar," and just where it was causing the grass to tremble and fall. Without his assistance the swallows would doubtless have gone hungry yet another day.

Of the hen-hawk, he has observed that both male and female take part in incubation. "I was rather surprised," he says, "on one occasion, to see how quickly they change places on the nest. The nest was in a tall beech, and the leaves were not yet fully out. I could see the head and neck of the hawk over the edge of the nest, when I saw the other hawk coming down through the air at full speed. I expected he would alight near by, but instead of that he struck directly upon the nest, his mate getting out of the way barely in time to avoid being hit; it seemed almost as if he had knocked her off the nest. I hardly see how they can make such a rush on the nest without danger to the eggs."

The kingbird will worry the hawk as a whiffet dog will worry a bear. It is by his persistence and audacity, not by any injury he is capable of dealing his great antagonist. The kingbird seldom more than dogs the hawk, keeping above and between his wings, and making a great ado; but my correspondent says he once "saw a kingbird riding on a hawk's back. The hawk flew as fast as possible, and the kingbird sat upon his shoulders in triumph until they had passed out of sight," - tweaking his 
feathers, no doubt, and threatening to scalp him the next moment.

That near relative of the kingbird, the great crested flycatcher, has one well-known peculiarity: he appears never to consider his nest finished until it contains a cast-off snake-skin. My alert correspondent one day saw him eagerly catch up an onion skin and make off with it, either deceived by it or else thinking it a good substitute for the coveted material.

One day in May, walking in the woods, I came upon the nest of a whip-poor-will, or rather its eggs, for it builds no nest, - two elliptical whitish spotted eggs lying upon the dry leaves. My foot was within a yard of the mother bird before she flew. I wondered what a sharp eye would detect curious or characteristic in the ways of the bird, so I came to the place many times and had a look. It was always a task to separate the bird from her surroundings, though I stood within a few feet of her, and knew exactly where to look. One had to bear on with his eye, as it were, and refuse to be baffled. The sticks and leaves, and bits of black or dark brown bark, were all exactly copied in the bird's plumage. And then she did sit so close, and simulate so well a shapeless, decaying piece of wood or bark! Twice I brought a companion, and, guiding his eye to the spot, noted how difficult it was for him to make out there, in full view upon the dry leaves, any semblance to a bird. When the bird returned after being disturbed, she would alight within a few inches of 
her eggs, and then, after a moment's pause, hobble awkwardly upon them.

After the young had appeared, all the wit of the bird came into play. I was on hand the next day, I think. The mother bird sprang up when I was within a pace of her, and in doing so fanned the leaves with her wings till they sprang up, too; as the leaves started the young started, and, being of the same color, to tell which was the leaf and which the bird was a trying task to any eye. I came the next day, when the same tactics were repeated. Once a leaf fell upon one of the young birds and nearly hid it. The young are covered with a reddish down, like a young partridge, and soon follow their mother about. When disturbed, they gave but one leap, then settled down, perfectly motionless and stupia, with eyes closed. The parent bird, on these occasions, made frantic efforts to decoy me away from her young. She would fly a few paces and fall upon her breast, and a spasm, like that of death, would run through her tremulous outstretched wings and prostrate body. She kept a sharp eye out the meanwhile to see if the ruse took, and, if it did not, she was quickly cured, and, moving about to some other point, tried to draw my attention as before. When followed she always alighted upon the ground, dropping down in a sudden peculiar way. The second or third day both old and young had disappeared.

The whip-poor-will walks as awkwardly as a swallow, which is as awkward as a man in a bag, and yet she manages to lead her young about the woods. 
The latter, I think, move by leaps and sudden spurts, their protective coloring shielding them most effec. tively. Wilson once came upon the mother bird and her brood in the woods, and, though they were at his very feet, was so baffled by the concealment of the young that he was about to give up the search, much disappointed, when he perceived something "like a slight mouldiness among the withered leaves, and, on stooping down, discovered it to be a young whip-poor-will, seemingly asleep." Wilson's description of the young is very accurate, as its downy covering does look precisely like a "slight mouldiness." Returning a few moments afterward to the spot to get a pencil he had forgotten, he could find neither old nor young.

It takes an eye to see a partridge in the woods, motionless upon the leaves; this sense needs to be as sharp as that of smell in hounds and pointers, and yet I know an unkempt youth that seldom fails to see the bird and shoot it before it takes wing. I think he sees it as soon as it sees him, and before it suspects itself seen. What a training to the eye is hunting! to pick out the game from its surroundings, the grouse from the leaves, the gray squirre! from the mossy oak limb it hugs so closely, the red fox from the ruddy or brown or gray field, the rabbit from the stubble, or the white hare from the snow, requires the best powers of this sense. A woodchuck motionless in the fields or upon a rock looks very much like a large stone or bowlder, yet a keen eye knows the difference at a glance, a quarter of a mile away. 
A man has a sharper eye than a dog, or a fox, or than any of the wild creatures, but not so sharp as ear or nose. But in the birds he finds his match. How quickly the old turkey discovers the hawk, a mere speck against the sky, and how quickly the hawk discovers you if you happen to be secreted in the bushes, or behind the fence near which he alights! One advantage the bird surely has, and that is, owing to the form, structure, and position of the eye, it has a much larger field of vision, - indeed, can probably see in nearly every direction at the same instant, behind as well as before. Man's field of vision embraces less than half a circle horizontally, and still less vertically; his brow and brain prevent him from seeing within many degrees of the zenith without a movement of the head; the bird, on the other hand, takes in nearly the whole sphere at a glance.

I find I see, almost without effort, nearly every bird within sight in the field or wood I pass through (a flit of the wing, a flirt of the tail are enough, though the flickering leaves do all conspire to hide them), and that with like ease the birds see me, though unquestionably the chances are immensely in their favor. The eye sees what it has the means of seeing, truly. You must have the bird in your heart before you can find it in the bush. The eye must have purpose and aim. No one ever yet found the walking fern who did not have the walking fern in his mind. A person whose eye is full of Indian relics picks them up in every field he walks through. 
One season I was interested in the tree-frogs, especially the tiny piper that one hears about the woods and brushy fields, - the hyla of the swamps become a denizen of the trees; I had never seen him in this new rôle. But this season, having hylas in mind, or rather being ripe for them, I several times came across them. One Sunday, walking amid some bushes, I captured two. They leaped before me, as doubtless they had done many times before; but though I was not looking for or thinking of them, yet they were quickly recognized, because the eye had been commissioned to find them. On another occasion, not long afterward, I was hurriedly loading my gun in the October woods in hopes of overtaking a gray squirrel that was fast escaping through the treetops, when one of these lilliput frogs, the color of the fast-yellowing leaves, leaped near me. I saw him only out of the corner of my eye and yet bagged him, because I had already made him my own.

Nevertheless the habit of observation is the habit of clear and decisive gazing: not by a first casual glance, but by a steady, deliberate aim of the eye, are the rare and characteristic things discovered. You must look intently, and hold your eye firmly to the spot, to see more than do the rank and file of mankind. The sharpshooter picks out his man, and knows him with fatal certainty from a stump, or a rock, or a cap on a pole. The phrenologists do well to locate, not only form, color, weight, etc., in the region of the eye, but a faculty which they call individuality, - that which separates, discriminates, 
and sees in every object its essential character. This is just as necessary to the naturalist as to the artist or the poet. The sharp eye notes specific points and differences, - it seizes upon and preserves the individuality of the thing.

Persons frequently describe to me some bird they have seen or heard, and ask me to name it, but in most cases the bird might be any one of a dozen, or else it is totally unlike any bird found on this continent. They have either seen falsely or else vaguely. Not so the farm youth who wrote me one winter day that he had seen a single pair of strange birds, which he describes as follows: "They were about the size of the 'chippie;' the tops of their heads were red, and the breast of the male was of the same color, while that of the female was much lighter; their rumps were also faintly tinged with red. If I have described them so that you would know them, please write me their names." There can be little doubt but the young observer had seen a pair of redpolls, - a bird related to the goldfinch, and that occasionally comes down to us in the winter from the far north. Another time, the same youth wrote that he had seen a strange bird, the color of a sparrow, that alighted on fences and buildings as well as upon the ground, and that walked. This last fact showed the youth's discriminating eye and settled the case. From this and the season, and the size and color of the bird, I knew he had seen the pipit or titlark. But how many persons would have observed that the bird walked instead of hopped? 
Some friends of mine who lived in the country tried to descril, to me a bird that built a nest in a tree within a few feet of the house. As it was a brown bird, I should have taken it for a wood thrush, had not the nest been described as so thin and loose that from beneath the eggs could be distinctly seen. The most pronounced feature in the description was the barred appearance of the under side of the bird's tail. I was quite at sea, until one day, when we were driving out, a cuckoo flew across the road in front of us, when my friends exclaimed, "There is our bird!" I had never known a cuckoo to build near a house, and I had never noted the appearance the tail presents when viewed from beneath; but if the bird had been described in its most obvious features, as slender, with a long tail, cinnamon brown above and white beneath, with a curved bill, any one who knew the bird would have recognized the portrait.

We think we have looked at a thing sharply until we are asked for its specific features. I thought I knew exactly the form of the leaf of the tulip-tree, until one day a lady asked me to draw the outlines of one. A good observer is quick to take a hint and to follow it up. Most of the facts of nature, especially in the life of the birds and animals, are well screened. We do not see the play because we do not look intently enough. The other day I was sitting with a friend upon a high rock in the woods, near a small stream, when we saw a water-snake swimming across a pool toward the opposite bank. 
Any eye would have noted it, perhaps nothing more. A little closer and sharper gaze revealed the fact that the snake bore something in its mouth, which, as we went down to investigate, proved to be a small catfish, three or four inches long. The snake had captured it in the pool, and, like any other fisherman, wanted to get its prey to dry land, although it itself lived mostly in the water. Here, we said, is being enacted a little tragedy that would have escaped any but sharp eyes. The snake, which was itself small, had the fish by the throat, the hold of vantage among all creatures, and clung to it with great tenacity. The snake knew that its best tactics was to get upon dry land as soon as possible. It could not swallow its victim alive, and it could not strangle it in the water. For a while it tried to kill its game by holding it up out of the water, but the fish grew heavy, and every few moments its struggles brought down the snake's head. This would not do. Compressing the fish's throat would not shut off its breath under such circumstances, so the wily serpent tried to get ashore with it, and after several attempts succeeded in effecting a landing on a Hat rock. But the fish died hard. Catfish do not give up the ghost in a hurry. Its throat was becoming congested, but the snake's distended jaws must have ached. It was like a petrified gape. Then the spectators became very curious and close in their scrutiny, and the snake determined to withdraw from the public gaze and finish the business in hand to its own notions. But, when gently but 
firmly remonstrated with by my friend with his walking-stick, it dropped the fish and retreated in high dudgeon beneath a stone in the bed of the creek. The fish, with a swollen and angry throat, went its way also.

Birds, I say, have wonderfully keen eyes. Throw

fresh bone or a piece of meat upon the snow in winter, and see how soon the crows will discover it and be on hand. If it be near the house or barn, the crow that first discovers it will alight near it, to make sure he is not deceived; then he will go away, and soon return with a companion. The two alight a few yards from the bone, and after some delay, during which the vicinity is sharply scrutinized, one of the crows advances boldly to within a few feet of the coveted prize. Here he pauses, and if no trick is discovered, and the meat be indeed meat, he seizes it and makes off.

One midwinter I cleared away the snow under an apple-tree near the house and scattered some corn there. I had not seen a blue jay for weeks, yet that very day they found my corn, and after that they came daily and partook of it, holding the kernels under their feet upon the limbs of the trees and pecking them vigorously.

Of course the woodpecker and his kind have sharp eyes, still I was surprised to see how quickly Downy found out some bones that were placed in a convenient place under the shed to be pounded up for the hens. In going out to the barn I often disturbed him making a meal off the bits of meat that still adhered to them. 
"Look intently enough at anything," said a poet to me one day, "and you will see something that would otherwise escape you." I thought of the remark as I sat on a stump in an opening of the woods one spring day. I saw a small hawk approaching; he flew to a tall tulip-tree, and alighted on a large limb near the top. He eyed me and I eyed him. Then the bird disclosed a trait that was new to me: he hopped along the limb to a small cavity near the trunk, when he thrust in his head and pulled out some small object and fell to eating it. After he had partaken of it for some minutes he put the remainder back in his larder and flew away. I had seen something like feathers eddying slowly down as the hawk ate, and on approaching the spot found the feathers of a sparrow here and there clinging to the bushes beneath the tree. The hawk, then, commonly called the chicken hawk, - is as provident as a mouse or squirrel, and lays by a store against a time of need, but I should not have discovered the fact had I not held my eye to him.

An observer of the birds is attracted by any unusual sound or commotion among them. In May or June when other birds are most vocal, the jay is a silent bird; he goes sneaking about the orchards and the groves as silent as a pickpocket; he is robbing birds'-nests, and he is very anxious that nothing should be said about it, but in the fall none so quick and loud to cry "Thief, thief!" as he. One December morning a troop of them discovered a little screech owl secreted in the hollow trunk of an old 
apple-tree near my house. How they found the owl out is a mystery, since it never ventures forth in the light of day; but they did, and proclaimed the fact with great emphasis. I suspect the bluebirds first told them, for these birds are constantly peeping into holes and crannies, both spring and fall. Some unsuspecting bird probably entered the cavity prospecting for a place for next year's nest, or else looking out a likely place to pass a cold night, when it has rushed out with important news. A boy who should unwittingly venture into a bear's den when Bruin was at home could not be more astonished and alarmed than a bluebird would be on finding itself in the cavity of a decayed tree with an owl. At any rate, the bluebirds joined the jays in calling the attention of all whom it might concern to the fact that a culprit of some sort was hiding from the light of day in the old apple-tree. I heard the notes of warning and alarm and approached to within eyeshot. The bluebirds were cautious and hovered about uttering their peculiar twittering calls; but the jays were bolder and took turns looking in at the cavity, and deriding the poor, shrinking owl. A jay would alight in the entrance of the hole, and flirt and peer and attitudinize, and then fly away crying "Thief, thief, thief!" at the top of his voice.

I climbed up and peered into the opening, and could just descry the owl clinging to the inside of the tree. I reached in and took him out, giving little heed to the threatening snapping of his beak. He was as red as a fox and as yellow-eyed as a cat. 
He made no effort to escape, but planted his claws in my forefinger and clung there with a grip that soon grew uneomfortable. I placed him in the loft of an outhouse, in hopes of getting better acquainted with him. By day he was a very willing prisoner, searcely moving at all, even when approached and touched with the hand, but looking out upon the world with half-closed, sleepy eyes. But at night what a change! how alert, how wild, how active! He was like another bird; he darted about with wide, fearful eyes, and regarded me like a cornered cat. I opened the window, and swiftly, but as silent as a shadow, he glided out into the congenial darkness, and perhaps, ere this, has revenged himself upon the sleeping jay or bluebird that first betrayed his hiding-place. 



\section{III}

\section{STRAWBERRIES}

Was it old Dr. Parr who said or sighed in his last illness, "Oh, if I can only live till strawberries come!" The old scholar imagined that, if he could weather it till then, the berries would carry him through. No doubt he had turned from the drugs and the nostrums, or from the hateful food, to the memory of the pungent, penetrating, and unspeakably fresh quality of the strawberry with the deepest longing. The very thought of these crimson lobes, embodying as it were the first glow and ardor of the young summer, and with their power to unsheathe the taste and spur the flagging appetite, made life seem possible and desirable with him.

The strawberry is always the hope of the invalid, and sometimes, no doubt, his salvation. It is the first and finest relish among fruits, and well merits Dr. Boteler's memorable saying, that "doubtless God could have made a better berry, but doubtless God never did."

On the threshold of summer, Nature proffers us this her virgin fruit; more rich and sumptuous are to follow, but the wild delicacy and fillip of the strawberry are never repeated, - that keen feathered edge greets the tongue in nothing else. 
Let me not be afraid of overpraising it, but probe and probe for words to hint its surprising virtues. We may well celebrate it with festivals and music. It has that indescribable quality of all first things, - that shy, uncloying, provoking barbed sweetness. It is eager and sanguine as youth. It is born of the copious dews, the fragrant nights, the tender skies, the plentiful rains of the early season. The singing of birds is in it, and the health and frolic of lusiy Nature. It is the product of liquid May touched by the June sun. It has the tartness, the briskness, the unruliness of spring, and the aroma and intensity of summer.

Oh the strawberry days! how vividly they come back to one! The smell of clover in the fields, of blooming rye on the hills, of the wild grape beside the woods, and of the sweet honeysuckle and spiræa about the house. The first hot, moist days. The daisies and buttercups; the songs of the birds, their first reckless jollity and love-making over; the full tender foliage of the trees; the bees swarming, and the air strung with resonant musical chords. The time of the sweetest and most succulent grass, when the cows come home with aching udders. Indeed, the strawberry belongs to the juciest time of the year.

What a challenge it is to the taste! how it bites back again! and is there any other sound like the snap and crackle with which it salutes the ear on being plucked from the stems? It is a threat to one sense that the other is soon to verify. It snaps 
to the ear as it smacks to the tongue. All other berries are tame beside it.

The plant is almost an evergreen; it loves the coverlid of the snow, and will keep fresh through the severest winters with a slight protection. The frost leaves its virtues in it. The berry is a kind of vegetable snow. How cool, how tonic, how melting, and how perishable! It is almost as easy to keep frost. Heat kills it, and sugar quickly breaks up its cells.

Is there anything like the odor of strawberries? The next best thing to tasting them is to smell them; one may put his nose to the dish while the fruit is yet too rare and choice for his fingers. Touch not and taste not, but take a good smell and go mad! Last fall I potted some of the Downer, and in the winter grew them in the house. In March the berries were ripe, only four or five on a plant, just enough, all told, to make one consider whether it were not worth while to kill off the rest of the household, so that the berries need not be divided. But if every tongue could not have a feast, every nose banqueted daily upon them. They filled the house with perfume. The Downer is remarkable in this respect. Grown in the open field, it surpasses in its odor any strawberry of my acquaintance. And it is scarcely less agreeable to the taste. It is a very beautiful berry to look upon, round, light pink, with a delicate, fine-grained expression. Some berries shine, the Downer glows as if there were a red bloom upon it. Its core is firm and white. its skin thın 
and easily bruised, which makes it a poor market berry, but, with its high flavor and productiveness, an admirable one for home use. It seems to be as easily grown as the Wilson, while it is much more palatable. The great trouble with the Wilson, as everybody knows, is its rank acidity. When it first comes, it is difficult to eat it without making faces. It is crabbed and acrimonious. Like some persons, the Wilson will not ripen and sweeten till its old age. Its largest and finest crop, if allowed to remain on the vines, will soften and fail unregenerated, or with all its sins upon it. But wait till toward the end of the season, after the plant gets over its hurry and takes time to ripen its fruit. The berry will then face the sun for days, and, if the weather is not too wet, instead of softening will turn dark and grow rich. Out of its crabbedness and spitefulness come the finest, choicest flavors. It is an astonishing berry. It lays hold of the taste in a way that the aristocratic berries, like the Jocunda or Triumph, cannot approximate to. Its quality is as penetrating as that of ants and wasps, but sweet. It is, indeed, a wild bee turned into a berry, with the sting mollified and the honey disguised. A quart of these rare-ripes I venture to say contains more of the peculiar virtue and excellence of the strawberry kind than can be had in twice the same quantity of any other cultivated variety. Take these berries in a bowl of rich milk with some bread, ah, what a dish! - too good to set before a king! I suspect this was the food of Adam in Paradise, only 
Adam did not have the Wilson strawberry; he had the wild strawberry that Eve plucked in their hillmeadow and "hulled" with her own hands, and that, take it all in all, even surpasses the late-ripened Wilson.

Adam is still extant in the taste and appetite of most country boys; lives there a country boy who does not like wild strawberries and milk, - yea, prefers it to any other known dish? I am not thinking of a dessert of strawberries and cream; this the city boy may have, too, after a sort; but bread-andmilk, with the addition of wild strawberries, is peculiarly a country dish, and is to the taste what a wild bird's song is to the ear. When I was a lad, and went afield with my hoe or with the cows, during the strawberry season, I was sure to return at meal-time with a lining of berries in the top of my straw hat. They were my daily food, and I could taste the liquid and gurgling notes of the bobolink in every spoonful of them; and at this day, to make a dinner or supper off a bowl of milk with bread and strawberries, - plenty of strawberries, - well, is as near to being a boy again as I ever expect to come. The golden age draws sensibly near. Appetite becomes a kind of delicious thirst, - a gentle and subtle craving of all parts of the mouth and throat, - and those nerves of taste that occupy, as it were, a back seat, and take little cognizance of grosser foods, come forth, and are played upon and set vibrating. Indeed, I think, if there is ever rejoicing throughout one's alimentary household, - 
if ever that much-abused servant, the stomach, says Amen, or those faithful handmaidens, the liver and spleen, nudge each other delightedly, it must be when one on a torrid summer day passes by the solid and carnal dinner for this simple Arcadian dish.

The wild strawberry, like the wild apple, is spicy and high-flavored, but, unlike the apple, it is also mild and delicious. It has the true rustic sweetness and piquancy. What it lacks in size, when compared with the garden berry, it makes up in intensity. It is never dropsical or overgrown, but firm-fleshed and hardy. Its great enemies are the plow, gypsum, and the horse-rake. It dislikes a limestone soil, but seems to prefer the detritus of the stratified rock. Where the sugar maple abounds, I have always found plenty of wild strawberries. IVe have two kinds, - the wood berry and the field berry. The former is as wild as a partridge. It is found in open places in the woods and along the borders, growing beside stumps and rocks, never in abundance, but very sparsely. It is small, cone-shaped, dark red, shiny, and pimply. It looks woody, and tastes so. It has never reached the table, nor made the acquaintance of cream. A quart of them, at a fair price for human labor, would be worth their weight in silver at least. (Yet a careful observer writes me that in certain sections in the western part of New York they are very plentiful.)

Ovid mentions the wood strawberry, which would lead one to infer that they were more abundant in his time and country than in ours. 
This is, perhaps, the same as the alpine strawberry, which is said to grow in the mountains of Greece, and thence northward. This was probably the first variety cultivated, though our native species would seem as unpromising a subject for the garden as club-moss or wintergreens.

Of the field strawberry there are a great many varieties, - some growing in meadows, some in pastures, and some upon mountain-tops. Some are round, and stick close to the calyx or hull; some are long and pointed, with long, tapering necks. These usually grow upon tall stems. They are, indeed, of the slim, linear kind. Your corpulent berry keeps close to the ground; its stem and foot-stalk are short, and neck it has none. Its color is deeper than that of its tall brother, and of course it has more juice. You are more apt to find the tall varieties upon knolls in low, wet meadows, and again upon mountain-tops, growing in tussocks of wild grass about the open summits. These latter ripen in July, and give one his last taste of strawberries for the season.

But the favorite haunt of the wild strawberry is an uplying meadow that has been exempt from the plow for five or six years, and that has little timothy and much daisy. When you go a-berrying, turn your steps toward the milk-white meadows. The slightly bitter odor of the daisies is very agreeable to the smell, and affords a good background for the perfume of the fruit. The strawberry cannot cope with the rank and deep-rooted clover, and seldom 
appears in a field till the clover has had its day. But the daisy with its slender stalk does not crowd or obstruct the plant, while its broad white flower is like a light parasol that tempers and softens the too strong sunlight. Indeed, daisies and strawberries are generally associated. Nature fills her dish with the berries, then covers them with the white and yellow of milk and cream, thus suggesting a combination we are quick to follow. Milk alone, after it loses its animal heat, is a clod, and begets torpidity of the brain; the berries lighten it, give wings to it, and one is fed as by the air he breathes or the water he drinks.

Then the delight of "picking" the wild berries! It is one of the fragrant memories of boyhood. Indeed, for boy or man to go a-berrying in a certain pastoral country I know of, where a passer-by along the highway is often regaled by a breeze loaded with a perfume of the o'er-ripe fruit, is to get nearer to June than by almost any course I know of. Your errand is so private and confidential! You stoop low. You part away the grass and the daisies, and would lay bare the inmost secrets of the meadow. Everything is yet tender and succulent; the very anr is bright and new; the warm breath of the meadow comes up in your face; to your knees you are in a sea of daisies and clover; from your knees up, you are in a sea of solar light and warmth. Now you are prostrate like a swimmer, or like a surfbather reaching for pebbles or shells, the white and green spray breaks above you; then, like a devoteo 
before a shrine, or naming his beads, your rosary strung with luscious berries; anon you are a grazing Nebuchadnezzar, or an artist taking an inverted view of the landscape.

The birds are alarmed by your close scrutiny of their domain. They hardly know whether to sing or to cry, and do a little of both. The bobolink follows you and circles above and in advance of you, and is ready to give you a triumphal exit from the field, if you will only depart.

"Ye boys that gather flowers and strawberries, Lo, hid within the grass, an adder lies,"

Warton makes Virgil sing; and Montaigne, in his "Journey to Italy," says: "The children very often are afraid, on account of the snakes, to go and pick the strawberries that grow in quantities on the mountains and among the bushes." But there is no serpent here, - at worst, only a bumblebee's or yellowjacket's nest. You soon find out the spring in the corner of the field under the beechen tree. Whils you wipe your brow anc thank the Lord for spring water, you glance at the initials in the bark, somo of them so old that they seem runic and legendary. You find out, also, how gregarious the strawberry is, - that the different varieties exist in little colonies about the field. When you strike the outskirts of one of these plantations, how quickly you work toward the centre of it, and then from the centre out, then circumnavigate it, and follow up all its branchings and windings!

Then the delight in the abstract and in the con- 
crete of strolling and lounging about the June meadows; of lying in pickle for half a day or more in this pastoral sea, laved by the great tide, shone upon by the virile sun, drenched to the very marrow of your being with the warm and wooirg influences of the young summer!

I was a famous berry-picker when a boy. It was near enough to hunting and fishing to enlist me. Mother would always send me in preference to any of the rest of the boys. I got the biggest berries and the most of them. There was something of the excitement of the chase in the occupation, and something of the charm and preciousness of game about the trophies. The pursuit had its surprises, its expectancies, its sudden disclosures, - in fact, its uncertainties. I went forth adventurously. I could wander free as the wind. Then there were moments of inspiration, for it always seemed a felicitous stroke to light upon a particularly fine spot, as it does when one takes an old and wary trout. You discovered the game where it was hidden. Your genius prompted you. Another had passed that way and had missed the prize. Indeed, the successful berrypicker, like Walton's angler, is born, not made. It is only another kind of angling. In the same field one boy gets big berries and plenty of them; another wanders up and down, and finds only a few little ones. He cannot see them; he does not know how to divine them where they lurk under the leaves and vines. The berry-grower knows that in the cultirated patch his pickers are very unequal, the baskets 
of one boy or girl having so inferior a look that it does not seem possible they could have been filled from the same vines with certain others. But neither blunt fingers nor blunt eyes are hard to find; and as there are those who can see nothing clearly, so there are those who can touch nothing deftly or gently.

The cultivation of the strawberry is thought to be comparatively modern. The ancients appear to have been a carnivorous race: they gorged themselves with meat; while the modern man makes larger and larger use of fruits and vegetables, until this generation is doubtless better fed than any that has preceded it. The strawberry and the apple, and such vegetables as celery, ought to lengthen human life, - at least to correct its biliousness and make it more sweet and sanguine.

The first impetus to strawberry culture seems to have been given by the introduction of our field berry (Fragaria Virginiana) into England in the seventeenth century, though not much progress was made till the eighteenth. This variety is much more fragrant and aromatic than the native berry of Europe, though less so in that climate than when grown here. Many new seedlings sprang from it, and it was the prevailing berry in English and French gardens, says Fuller, until the South American species, grandiflora, was introduced and supplanted it. This berry is naturally much larger and sweeter, and better adapted to the English climate, than our Virginiana. Hence the English strawberries of to-day 
surpass ours in these respects, but are wanting in that aromatic pungency that characterizes most of our berries.

The Jocunda, Triumph, Victoria, etc., are foreign varieties of the Grandiflora species; while the Hovey, the Boston Pine, the Downer, etc., are natives of this country.

The strawberry, in the main, repeats the form of the human heart, and perhaps, of all the small fruits known to man, none other is so deeply and fondly cherished, or hailed with such universal delight, as this lowly but youth-renewing berry. 


\section{IV}

IS IT GOING TO RAIN?

I SUSPECT that, like most countrymen, I was Is it going to rain or snow, be hot or cold, wet or dry? - are inquiries upon which I would fain get the views of every man I meet, and I find that most men are fired with the same desire to get my views upon the same set of subjects. To a countryman the weather means something, - to a farmer especially. The farmer has sowed and planted and reaped and vended nothing but weather all his life. The weather must lift the mortgage on his farm, and pay his taxes, and feed and clothe his family. Of what use is his labor unless seconded by the weather? Hence there is speculation in his eye whenever he looks at the clouds, or the moon, or tho sunset, or the stars; for even the Milky Way, in his view, may point the direction of the wind to-morrow, and hence is closely related to the price of butter. He may not take the sage's advice to "hitch his wagon to a star," but he pins his hopes to the moon, and plants and sows by its phases.

Then the weather is that phase of Nature in which she appears not the immutable fate we are so wont to 
regard her, but on the contrary something quite human and changeable, not to say womanish, - a creature of moods, of caprices, of cross purposes; gloomy and downcast to-day, and all light and joy to-morrow; caressing and tender one moment, and severe and frigid the next; one day iron, the next day vapor; inconsistent, inconstant, incalculable; full of genius, full of folly, full of extremes; to be read and understood, not by rule, but by subtle signs and indirections, - by a look, a glance, a presence, as we read and understand a man or a woman. Some days are like a rare poetic mood. There is a felicity and an exhilaration about them from morning till night. They are positive and fill one with celestial fire. Other days are negative and drain one of his electricity.

Sometimes the elements show a marked genius for fair weather, as in the fall and early winter of 1877 , when October, grown only a little stern, lasted till January. Every shuffle of the cards brought these mild, brilliant days uppermost. There was not enough frost to stop the plow, save once perhaps, till the new year set in. Occasionally a fruit-tree put out a blossom and developed young fruit. The warring of the elements was chiefly done on the other side of the globe, where it formed an accompaniment to the human war raging there. In our usually merciless skies was written only peace and good-will to men, for months.

What a creature of habit, too, Nature is as she appears in the weather! If she miscarry once she 
will twice and thrice, and a dozen times. In a wet time it rains to-day because it rained yesterday, and will rain to-morrow because it rained to-day. Are the crops in any part of the country drowning? They shall continue to drown. Are they burning ap? They shall continue to burn. The elements set in a rut and can't get out without a shock. I know a farmer who, in a dry time, when the clouds gather and look threatening, gets out his wateringpot at once, because, he says, "it won't rain, and 't is an excellent time to apply the water." Of course, there comes a time when the farmer is wrong, but he is right four times out of five.

But I am not going to abuse the weather; rather to praise it, and make some amends for the many ill-natured things I have said, within hearing of the clouds, when I have been caught in the rain or been narched and withered by the drought.

When Mr. Fields's "Village Dogmatist" was asked what caused the rain, or the fog, he leaned upon his cane and answered, with an air of profound wisdom, that "when the atmosphere and hemisphere come together it causes the earth to sweat, and thereby produces the rain," - or the fog, as the case may be. The explanation is a little vague, as his biographer suggests, but it is picturesque, and there can be little doubt that two somethings do come in contact that produce a sweating when it rains or is foggy. Nore than that, the philosophy is simple and comprehensive, which Goethe said was the main matter in such things. Goethe's explana- 
tion is still more picturesque, but I doubt if it is a bit better philosophy. "I compare the earth and her atmosphere," he said to Eckermann, "to a great living being perpetually inhaling and exhaling. If she inhale she draws the atmosphere to her, so that, coming near her surface, it is condensed to clouds and rain. This state I call water-affirmative." The opposite state, when the earth exhales and sends the watery vapors upward so that they are dissipated through the whole space of the higher atmosphere, he called "water-negative."

This is good literature, and worthy the great poet; the science of it I would not be so willing to vouch for.

The poets, more perhaps than the scientists, have illustrated and held by the great law of alternation, of ebb and flow, of turn and return, in nature. An equilibrium, or, what is the same thing, a straight line, Nature abhors more than she does a vacuum. If the moisture of the air were uniform, or the heat uniform, that is, in equilibrio, how could it rain? what would turn the scale? But these things are heaped up, are in waves. There is always a preponderance one way or the other; always "a steep inequality." Down this incline the rain comes, and up the other side it goes. The high barometer travels like the crest of a sea, and the low barometer like the trough. When the scale kicks the beam in one place, it is correspondingly depressed in some otherWhen the east is burning up, the west is generally drowning out. The weather, we say, is always in 
extremes; it never rains but it pours: but this is only the abuse of a law on the part of the elements which is at the bottom of all the life and motion on the globe.

The rain itself comes in shorter or longer waves, - now fast, now slow - and sometimes in regular throbs or pulse-beats. The fall and winter rains are, as a rule, the most deliberate and general, but the spring and summer rains are always more or less impulsive and capricious. One may see the rain stalking across the hills or coming up the valley in single file, as it were. Another time it moves in vast masses or solid columns, with broad open spaces between. I have seen a spring snowstorm lasting nearly all day that swept down in rapid intermittent sheets or gusts. The waves or pulsations of the storm were nearly vertical and were very marked. But the great fact about the rain is that it is the most beneficent of all the operations of nature; more immediately than sunlight even, it means life and growth. Moisture is the Eve of the physical world the soft teeming principle given to wife to Adam or heat, and the mother of all that lives. Sunshine abounds everywhere, but only where the rain or dew follows is there life. The earth had the sun long before it had the humid cloud, and will doubtless continue to have it after the last drop of moisture has perished or been dissipated. The moon has sunshine enough, but no rain; hence it is a dead world - a lifeless cinder. It is doubtless true that certain of the planets, as Saturn and Jupiter, have not 
yet reached the condition of the cooling and amelia rating rains, while in Mars vapor appears to be precipitated only in the form of snow; he is probably past the period of the summer shower. There are clouds and vapors in the sun itself, - clouds of flaming hydrogen and metallic vapors, and a rair every drop of which is a burning or molten meteor. Our earth itself has doubtless passed through the period of the fiery and consuming rains. Mr. Proc. tor thinks there may have been a time when its showers were downpourings of "muriatic, nitric, and sulphuric acid, not only intensely hot, but fiercely burning through their chemical activity." Think of a dew that would blister and destroy like the oil of vitriol! but that period is far behind us now. When this fearful fever was past and the earth began to "sweat;" when these soft, delicious drops began to come down, or this impalpable rain of the cloudless nights to fall, - the period of organic life was inaugurated. Then there was hope and a promise of the future. The first rain was the turningpoint, the spell was broken, relief was at hand. Then the blazing furies of the fore world began to give place to the gentler divinities of later times.

The first water, - how much it means! Seven tenths of man himself is water. Seven tenths of the human race rained down but yesterday! It is much more probable that Alexander will flow out of a bunghole than that any part of his remains will ever stop one. Our life is indeed a vapor, a breath, a littlo moisture condensed upon the pane. We carry our- 
selves as in a phial. Cleave the flesh, and how quickly we spill out! Man begins as a fish, and he swims in a sea of vital fluids as long as his life lasts. His first food is milk; so is his last and all between. Ho can taste and assimilate and absorb nothing but liquids. The same is true throughout all organic nature. ' $\mathrm{T}$ is water-power that makes every wheel move. Without this great solvent, there is no life. I admire immensely this line of Walt Whitman:"The slumbering and liquid trees."

The tree and its fruit are like a sponge which the rains have filled. Through them and through all living bodies there goes on the commerce of vital growth, tiny vessels, fleets and succession of fleets, laden with material bound for distant shores, to build up, and repair, and restore the waste of the physical frame.

Then the rain means relaxation; the tension in Nature and in all her creatures is lessened. The trees drop their leaves, or let go their ripened fruit. The tree itself will fall in a still, damp day, when but yesterday it withstood a gale of wind. A moist south wind penetrates even the mind and makes its grasp less tenacious. It ought to take less to kill a man on a rainy day than on a clear. The direct support of the sun is withdrawn; life is under a cloud; a masculine mood gives place to something like a feminine. In this sense, rain is the grief, the weeping of Nature, the relief of a burdened or agonized heart. But tears from Nature's eyelids are always remedial and prepare the way for brighter, purer skies. 
I think rain is as necessary to the mind as to vegetation. Who does not suffer in his spirit in a drought and feel restless and unsatisfied? My very thoughts become thirsty and crave the moisture. It is hard work to be generous, or neighborly, or patriotic in a dry time, and as for growing in any of the finer graces or virtues, who can do it? One's very manhood shrinks, and, if he is ever capable of a mean act or of narrow views, it is then.

Oh the terrible drought! When the sky turns to brass; when the clouds are like withered leaves; when the sun sucks the earth's blood like a vampire; when rivers shrink, streams fail, springs perish; when the grass whitens and crackles under your feet; when the turf turns to dust; when the fields are like tinder; when the air is the breath of an oven; when even the merciful dews are withheld, and the morning is no fresher than the evening; when the friendly road is a desert, and the green woods like a sick-chamber; when the sky becomes tarnished and opaque with dust and smoke; when the shingles on the houses curl up, the clapboards warp, the paint blisters, the joints open; when the cattle rove disconsolate and the hive-bee comes home empty; when the earth gapes and all nature looks widowed, and deserted, and heart-broken, — in such a time, what thing that has life does not sympathize and suffer with the general distress?

The drought of the summer and early fall of 1876 was one of those severe stresses of weather that make the oldest inhabitant search his memory for a par- 
allel. For nearly three months there was no rain to wet the ground. Large forest trees withered and cast their leaves. In spots, the mountains looked as if they had been scorched by fire. The salt seawater came up the Hudson ninety miles, when ordinarily it scarcely comes forty. Toward the last, the capacity of the atmosphere to absorb and dissipate the smoke was exhausted, and innumerable fires in forests and peat-swamps made the days and the weeks - not blue, but a dirty yellowish white. There was not enough moisture in the air to take the sting out of the smoke, and it smarted the nose. The sun was red and dim even at midday, and at his rising and setting he was as harmless to the eye as a crimson shield or a painted moon. The meteorological conditions seemed the farthest possible remove from those that produce rain, or even dew. Every sign was negatived. Some malevolent spirit seemed abroad in the air, that rendered abortive svery effort of the gentler divinities to send succor. The clouds would gather back in the mountains, the thunder would growl, the tall masses would rise up and advance threateningly, then suddenly cower, their strength and purpose ooze away; they flattened out; the hot, parched breath of the earth smote them; the dark, heavy masses were re-resolved into thin vapor, and the sky came through where but a Dow moments before there had appeared to be deep behind deep of water-logged clouds. Sometimes a cloud would pass by, and one could see trailing bereath and behind it a sheet of rain, like something 
let down that did not quite touch the earth, the hot air vaporizing the drops before they reached the ground.

Two or three times the wind got in the south, and those low, dun-colored clouds that are nothing but harmless fog came hurrying up and covered the sky, and city folk and women folk said the rain was at last near. But the wise ones knew better. The clouds had no backing, the clear sky was just behind them; they were only the nightcap of the south wind, which the sun burnt up before ten o'clock.

Every storm has a foundation that is deeply and surely laid, and those shallow surface-clouds that have no root in the depths of the sky deceive none but the unwary.

At other times, when the clouds were not reabsorbed by the sky and rain seemed imminent, they would suddenly undergo a change that looked like curdling, and when clouds do that no rain need be expected. Time and again I saw their continuity broken up, saw them separate into small masses, in fact saw a process of disintegration and disorganization going on, and my hope of rain was over for that day. Vast spaces would be affected suddenly; it was like a stroke of paralysis: motion was retarded, the breeze died down, the thunder ceased, and the storm was blighted on the very threshold of success.

I suppose there is some compensation in a drought; Nature doubtless profits by it in some way. It is a good time to thin out her garden, and give the law 
of the survival of the fittest a chance to come into play. How the big trees and big plants do rob the little ones! there is not drink enough to go around, and the strongest will have what there is. It is a rest to vegetation, too, a kind of torrid winter that is followed by a fresh awakening. Every tree and plant learns a lesson from it, learns to shoot its roots down deep into the perennial supplies of moisture and life.

But when the rain does come, the warm, sun-distilled rain; the far-traveling, vapor-born rain; the impartial, undiscriminating, unstinted rain; equable, bounteous, myriad-eyed, searching out every plant and every spear of grass, finding every hidden thing that needs water, falling upon the just and upon the unjust, sponging off every leaf of every tree in the forest and every growth in the fields; music to the ear, a perfume to the smell, an enchantment to the eye; healing the earth, cleansing the air, renewing the fountains; honey to the bee, manna to the herds, and life to all creatures, - what spectacle so fills the heart? "Rain, rain, $\mathrm{O}$ dear Zeus, down on the plowed fields of the Athenians, and on the plains."

There is a fine sibilant chorus audible in the sod, and in the dust of the road, and in the porous plowed fields. Every grain of soil and every root and rootlet purrs in satisfaction. Because something more than water comes down when it rains; you cannot produce this effect by simple water; the good-will of the elements, the consent and approbation of all 
the skyey influences, come down; the harmony, the adjustment, the perfect understanding of the soil beneath and the air that swims above, are implied in the marvelous benefaction of the rain. The earth is ready; the moist winds have wooed it and prepared it, the electrical conditions are as they should be, and there are love and passion in the surrender of the summer clouds. How the drops are absorbed into the ground! You cannot, I say, succeed like this with your hose or sprinkling-pot. There is no ardor or electricity in the drops, no ammonia, or ozone, or other nameless properties borrowed from the air.

Then one has not the gentleness and patience of Nature; we puddle the ground in our hurry, re seal it up and exclude the air, and the plants are worse off than before. When the sky is overcast and it is getting ready to rain, the moisture rises in the ground, the earth opens her pores and secorals the desire of the clouds.

Indeed, I have found there is but little virtue in a sprinkling-pot after the drought has reached a certain pitch. The soil will not absorb the water. 'T is like throwing it on a hot stove. I once concen ${ }^{2}$ rated my efforts upon a single hill of corn and deluged it with water night and morning for several days: yet its leaves curled up and the ears failed the sama as the rest. Something may be done, without dount, if one begins in time, but the relief seems strange ly inadequate to the means often used. In rainleas countries good crops are produced by irrigation, but 
here man can imitate in a measure the patience and bounty of Nature, and, with night to aid him, can make his thirsty fields drink, or rather can pour the water down their throats.

I have said the rain is as necessary to man as to vegetation. You cannot have a rank, sappy race, like the English or German, without plenty of moisture in the air and in the soil. Good viscera and an abundance of blood are closely related to meteorological conditions, unction of character, and a flow of animal spirits, too; and I suspect that much of the dry and rarefied humor of New England, as well as the thin and sharp physiognomies, are climatic results. We have rain enough, but not equability of temperature or moisture, - no steady, abundant supply of humidity in the air. In places in Great Britain it is said to rain on an average three days out of four the year through; yet the depth of rainfall is no greater than in this country, where it rains but the one day out of four. John Bull shows those three rainy days both in his temper and in his bodily habit; he is better for them in many ways, and perhaps not quite so good in a few others: they make him juicy and vascular, and maybe a little opaque; but we in this country could well afford a few of his negative qualities for the sake of his stomach and full-bloodedness.

We have such faith in the virtue of the rain, and in the capacity of the clouds to harbor and transport material good, that we more than half believe the stories of the strange and anomalous things that have 
fallen in showers. There is no credible report that it has ever yet rained pitchforks, but many other curious things have fallen. Fish, flesh, and fowl, and substances that were neither, have been picked up by veracious people after a storm. Manna, blood, and honey, frogs, newts, and fish-worms, are among the curious things the clouds are supposed to yield. If the clouds scooped up their water as the flying express train does, these phenomena could be easier explained. I myself have seen curious things. Riding along the road one day on the heels of a violent summer tempest, I saw the ground swarming with minute hopping creatures. I got out and captured my hands full. They proved to be tree-toads, many of them no larger than crickets, and none of them larger than a bumblebee. There seemed to be thousands of them. The mark of the tree-toad was the round, flattened ends of their toes. I took some of them home, but they died the next day. Where did they come from? I imagined the violent wind swept them off the trees in the woods to windward of the road. But this is only a guess; maybe they crept out of the ground, or from under the wall near by, and were out to wet their jackets.

I have never yet heard of a frog coming down chimney in a shower. Some circumstantial evidence may be pretty conclusive, Thoreau says, as when you find a trout in the milk; and if you find a frog or toad behind the fire-board immediately after a shower, you may well ask him to explain himself. 
When I was a boy I used to wonder if the clouds were hollow and carried their water as in a cask, because had we not often heard of clouds bursting and producing havoc and ruin beneath them? The hoops gave way, perhaps, or the head was pressed out. Goethe says that when the barometer rises, the clouds are spun off from the top downward like a distaff of flax; but this is more truly the process when it rains. When fair weather is in the ascendant, the clouds are simply reabsorbed by the air; but when it rains they are spun off into something more compact: ' $t$ is like the threads that issue from the mass of flax or roll of wool, only here there are innumerable threads and the fingers that hold them never tire. The great spinning-wheel, too, what a humming it makes at times, and how the footsteps of the invisible spinner resound through the cloud-pillared chambers!

The clouds are thus literally spun up into water; and were they not constantly recruited from the atmosphere as the storm-centre travels along, - was new wool not forthcoming from the white sheep and the black sheep that the winds herd at every point, - all rains would be brief and local; the storm would quickly exhaust itself, as we sometimes see a thinder-cloud do in summer. A storm will originate in the far West or Southwest - those hatchingplaces of all our storms - and travel across the continent, and across the Atlantic to Europe, pouring down incalculable quantities of rain as it progresses and recruiting as it wastes. It is a moving vortex 
into which the outlying moisture of the atmospher is being constantly drawn and precipitated. It is not properly the storm that travels, but the low pressure, the storm impulse, the meteorological magnet that makes the storm wherever its presence may be. The clouds are not watering-carts, that are driven all the way from Arizona or Colorado to Europe, but growths, developments that spring up as the Storm-deity moves his wand across the land. In advance of the storm, you may often see the clouds grow; the condensation of the moisture into vapor is a visible process; slender, spiculæ-like clouds expand, deepen, and lengthen; in the rear of the low pressure, the reverse process, or the wasting of the clouds, may be witnessed. In summer, the recruiting of a thunder-storm is often very marked. I have seen the clouds file as straight across the sky toward a growing storm or thunder-head in the horizon as soldiers hastening to the point of attack or defense. They would grow more and more black and threatening as they advanced, and actually seemed to be driven by more urgent winds than certain other clouds. They were, no doubt, more in the line of the storm influence.

All our general storms are cyclonic in their character, that is, rotary and progressive. Their type may be seen in every little whirlpool that goes down the swollen current of the river; and in our hemisphere they revolve in the same direction, namely, from right to left, or in opposition to the hands of a watch. When the water finds an outlet through 
the bottom of a dam, a suction or whirling vortex is developed that generally goes round in the same direction. A morning-glory or a hop-vine or a pole-bean winds around its support in the same course, and cannot be made to wind in any other. I am aware there are some perverse climbers among the plants that persist in going around the pole in the other direction. In the southern hemisphere the cyclone revolves in the other direction, or from left to right. How do they revolve at the equator, then? 'They do not revolve at all. This is the point of zero, and cyclones are never formed nearer than the third parallel of latitude. Whether hop-vines also refuse to wind about the pole thers I am unable to say.

All our cyclones originate in the far Southwest and travel northeast. Why did we wait for the Weather Bureau to tell us this fact? Do not all the filmy, hazy, cirrus and cirro-stratus clouds first appear from the general direction of the sunset? Who ever saw them pushing their opaque filaments over the sky from the east or north? Yet do we not have "northeasters" both winter and summer? True, but the storm does not come from that direction. In such a case we get that segment of tho cyclonic whirl. A northeaster in one place may bo an easter, a norther, or a souther in some other locality. See through those drifting, drenching clouds that come hurrying out of the northeast, and there are the boss-clouds above them, the great captains themselves, moving serenely on in the opposite direction. 
Electricity is, of course, an important agent in storms. It is the great organizer and ring-master. How a clap of thunder will shake down the rain! It gives the clouds a smart rap; it jostles the vapor so that the particles fall together more quickly; it makes the drops let go in double and treble ranks. Nature likes to be helped in that way, - likes to have the water agitated when she is freezing it or heating it, and the clouds smitten when she is compressing them into rain. So does a shock of surprise quicken the pulse in man, and in the crisis of action help him to a decision.

What a spur and impulse the summer shower is! How its coming quickens and hurries up the slow, jogging country life! The traveler along the dusty road arouses from his reverie at the warning rumble behind the hills; the children hasten from the field or from the school; the farmer steps lively and thinks fast. In the hay-field, at the first signal-gun of the elements, what a commotion! How the horserake rattles, how the pitchforks fly, how the white sleeves play and twinkle in the sun or against the dark background of the coming storm! One man does the work of two or three. It is a race with the elements, and the hay-makers do not like to be beaten. The rain that is life to the grass when growing is poison to it after it becomes cured hay, and it must be got under shelter, or put up into snug cocks, if possible, before the storm overtakes it.

The rains of winter are cold and odorless. One prefers the snow, which warms and covers; but can 
there be anything more delicious than the first warm April rain, - the first offering of the softened and pacified clouds of spring? The weather has been dry, perhaps, for two or three weeks; we have had a touch of the dreaded drought thus early; the roads are dusty, the streams again shrunken, and forest fires send up columns of smoke on every hand; the frost has all been out of the ground many days; the snow has all disappeared from the mountains; the sun is warm, but the grass does not grow, nor the early seeds come up. The quickening spirit of the rain is needed. Presently the wind gets in the southwest, and, late in the day, we have our first vernal shower, gentle and leisurely, but every drop condensed from warm tropic vapors and charged with the very essence of spring. Then what a perfume fills the air! One's nostrils are not half large enough to take it in. The smoke, washed by the rain, becomes the breath of woods, and the soil and the newly plowed fields give out an odor that dilates the sense. How the buds of the trees swell, how the grass greens, how the birds rejoice! Hear the robins laugh! This will bring out the worms and the insects, and start the foliage of the trees. A summer shower has more copiousness and power, but this has the charm of freshness and of all first things.

The laws of storms, up to a certain point, have come to be pretty well understood, but there is yet no science of the weather, any more than there is of human nature. There is about as much room for 
speculation in the one case as in the other. The causes and agencies are subtle and obscure, and wo shall, perhaps, have the metaphysics of the subject before we have the physics.

But as there are persons who can read human nature pretty well, so there are those who can read the weather.

It is a masculine subject, and quite beyond the province of woman. Ask those who spend their time in the open air, - the farmer, the sailor, the soldier, the walker; ask the birds, the beasts, the tree-toads: they know, if they will only tell. The farmer diagnoses the weather daily, as the doctor a patient: he feels the pulse of the wind; he knows when the clouds have a scurfy tongue, or when the cuticle of the day is feverish and dry, or soft and moist. Certain days he calls "weather-breeders," and they are usually the fairest days in the calendar, - all sun and sky. They are too fair; they are suspiciously so. They come in the fall and spring, and always mean mischief. When a day of almost unnatural brightness and clearness in either of these seasons follows immediately after a storm, it is a sure indication that another storm follows close, follows to-morrow. In keeping with this fact is the rule of the barometer, that, if the mercury suddenly rises very high, the fair weather will not last. It is a high peak that indicates a corresponding depression close at hand. I observed one of these angelic mischief-makers during the past October. The second day after a heavy fall of rain was the fairest of 
the fair, - not a speck or film in all the round of the sky. Where have all the clouds and vapors gone to so suddenly? was my mute inquiry, but I suspected they were plotting together somewhere behind the horizon. The sky was a deep ultramarine blue; the air so transparent that distant objects seemed near, and the afternoon shadows were sharp and clear. At night the stars were unusually numerous and bright (a sure sign of an approaching storm). The sky was laid bare, as the tidal wave empties the shore of its water before it heaps it up upon it. A violent storm of wind and rain the next day followed this delusive brightness. So the weather, like human nature, may be suspiciously transparent. A saintly day may undo you. A few clouds do not mean rain; but when there are absolutely none, when even the haze and filmy vapors are suppressed or held back, then beware.

Then the weather-wise know there are two kinds of clouds, rain-clouds and wind-clouds, and that the latter are always the most portentous. In summer they are black as night; they look as if they would blot out the very earth. They raise a great dust, and set things flying and slamming for a moment, and that is all. They are the veritable wind-bags of Eolus. There is something in the look of rainclouds that is unmistakable, - a firm, gray, tightly woven look that makes you remember your umbrella. Not too high nor too low, not black nor blue, but the form and hue of wet, unbleached linen. You see the river water in them; they are heavy-laden, 
and move slow. Sometimes they develop what are called "mares' tails," - small cloud-forms here and there against a heavy background, that look like the stroke of a brush, or the streaming tail of a charger. Sometimes a few under-clouds will be combed and. groomed by the winds or other meteoric agencies at work, as if for a race. I have seen coming storms develop well-defined vertebræ, - a long backbone of cloud, with the articulations and processes clearly marked. Any of these forms, changing, growing, denote rain, because they show unusual agencies at work. The storm is brewing and fermenting. "See those cowlicks," said an old farmer, pointing to certain patches on the clouds; "they mean rain." Another time, he said the clouds were "making bag," had growing udders, and that it would rain before night, as it did. This reminded me that the Orientals speak of the clouds as cows which the winds herd and milk.

In the winter, we see the sun wading in snow. The morning has perhaps been clear, but in the afternoon a bank of gray filmy or cirrus cloud meets him in the west, and he sinks deeper and deeper into it, till, at his going down, his muffled beams are entirely hidden. Then, on the morrow, not

"Announced by all the trumpets of the sky,"

but silent as night, the white legions are here.

The old signs seldom fail, - a red and angry sunrise, or flushed clouds at evening. Many a hope of rain have I seen dashed by a painted sky at sunset There is truth in the old couplet, too: - 
"If it rains before seven,

It will clear before eleven."

An old Indian had a sign for winter: "If tho wind blows the snow off the trees, the next storm will be snow; if it rains off, the next storm will be rain."

Morning rains are usually short-lived. Better wait till ten o'clock.

When the clouds are chilled, they turn blue and rise up.

When the fog leaves the mountains, reaching upward, as if afraid of being left behind, the fair weather is near.

Shoddy clouds are of little account, and soon fall to pieces. Have your clouds show a good strong fibre, and have them lined, - not with silver, but with other clouds of a finer texture, - and have them wadded. It wants two or three thicknesses to get up a good rain. Especially, unless you have that cloud-mother, that dim, filmy, nebulous mass that has its root in the higher regions of the air, and is the source and backing of all storms, your rain will be light indeed.

I fear my reader's jacket is not thoroughly soaked yet. I must give him a final dash, a "clear-up" shower.

We were encamping in the primitive woods, by a little trout-lake which the mountain carried high on his hip, like a soldier's canteen. There were wives in the party, curious to know what the lure was that annually drew their husbands to the woods. That 
magical writing on a trout's back they would fain decipher, little heeding the warning that what is written here is not given to woman to know.

Our only tent or roof was the sheltering arms of the great birches and maples. What was sauce for the gander should be sauce for the goose, too, so the goose insisted.

A luxurious couch of boughs upon springing poles was prepared, and the night should be not less welcome than the day, which had indeed been idyllic. (A trout dinner had been served by a little spring brook, upon an improvised table covered with moss and decked with ferns, with strawberries from a near clearing.)

At twilight there was an ominous rumble behind the mountains. I was on the lake, and could see what was brewing there in the west.

As darkness came on, the rumbling increased, and the mountains and the woods and the still air were such good conductors of sound that the ear was vividly impressed. One seemed to feel the enormous convolutions of the clouds in the deep and jarring tones of the thunder. The coming of night in the woods is alone peculiarly impressive, and it is doubly so when out of the darkness comes such a voice as this. But we fed the fire the more industriously, and piled the logs high, and kept the gathering gloom at bay by as large a circle of light as we could command. The lake was a pool of ink and as still as if congealed; not a movement or a sound, save now and then a terrific volley from the cloud bat- 
teries now fast approaching. By nine o'clock little puffs of wind began to steal through the woods and tease and toy with our fire. Shortly after, an enormous electric bombshell exploded in the treetops over our heads, and the ball was fairly opened. Then followed three hours, with oniy two brief intermissions, of as lively elemental music and as copious an outpouring of rain as it was ever my lot to witness. It was a regular meteorological carnival, and the revelers were drunk with the wild sport. The apparent nearness of the clouds and the electric explosion was something remarkable. Every discharge seemed to be in the branches immediately overhead and made us involuntarily cower, as if the next moment the great limbs of the trees, or the trees themselves, would come crashing down. The mountain upon which we were encamped appeared to be the focus of three distinct but converging storms. The last two seemed to come into collision immediately over our camp-fire, and to contend for the right of way, until the heavens were ready to fall and both antagonists were literally spent. We stood in groups about the struggling fire, and when the cannonade became too terrible would withdraw into the cover of the darkness, as if to be a less conspicuous mark for the bolts; or did we fear the fire, with its currents, might attract the lightning? At any rate, some other spot than the one where we happened to be standing seemed desirable when those onsets of the contending elements were the most furious. Something that one could not catch in his hat was liable 
to drop almost anywhere any minute. The alarm and consternation of the wives communicated itself to the husbands, and they looked solemn and concerned. The air was filled with falling water. The sound upon the myriad leaves and branches was like the roar of a cataract. We put our backs up against the great trees, only to catch a brook on our shoulders or in the backs of our necks. Still the storm waxed. The fire was beaten down lower and lower. It surrendered one post after another, like a besieged city, and finally made only a feeble resistance from beneath a pile of charred logs and branches in the centre. Our garments yielded to the encroachments of the rain in about the same manner. I believe my necktie held out the longest, and carried a few dry threads safely through. Our cunningly devised and bedecked table, which the housekeepers had so doted on and which was ready spread for breakfast, was washed as by the hose of a fire-engine, - only the bare poles remained, - and the couch of springing boughs, that was to make Sleep jealous and o'erfond, became a bed fit only for amphibians. Still the loosened floods came down; still the great cloudmortars bellowed and exploded their missiles in the treetops above us. But all nervousness finally passed away, and we became dogged and resigned. Our minds became water-soaked; our thoughts were heavy and bedraggled. We were past the point of joking at one another's expense. The witticisms failed to kindle, - indeed, failed to go, like the matches in our pockets. About midnight the rain 
slackened, and by one o'clock ceased entirely. How the rest of the night was passed beneath the dripping trees and upon the saturated ground, I have only the dimmest remembrance. All is watery and opaque; the fog settles down and obscures the scene. But I suspect I tried the "wet pack" without being a convert to hydropathy. When the morning dawned, the wives begged to be taken home, convinced that the charms of camping-out were greatly overrated. We, who had tasted this cup before, knew they had read at least a part of the legend of the wary trout without knowing it. 



\section{$\mathbf{\nabla}$ \\ SPECKLED TROUT}

I

THE legend of the wary trout, hinted at in tho 1 last sketch, is to be further illustrated in this and some following chapters. We shall get at more of the meaning of those dark water-lines, and I hope, also, not entirely miss the significance of the gold and silver spots and the glancing iridescent hues. The trout is dark and obscure above, but behind this foil there are wondrous tints that reward the believing eye. Those who seek him in his wild remote haunts are quite sure to get the full force of the sombre and uninviting aspects, - the wet, the cold, the toil, the broken rest, and the huge, savage, uncompromising nature, etc., - but the true angler sees farther than these, and is never thwarted of his legitimate reward by them.

I have been a seeker of trout from my boyhood, and on all the expeditions in which this fish has been the ostensible purpose I have brought home more game than my creel showed. In fact, in my mature years I find I got more of nature into me, more of the woods, the wild, nearer to bird and beast, while threading my native streams for trout, 
than in almost any other way. It furnished a good excuse to go forth; it pitched one in the right key; it sent one through the fat and marrowy places of field and wood. Then the fisherman has a harmless, preoccupied look; he is a kind of vagrant that nothing fears. He blends himself with the trees and the shadows. All his approaches are gentle and indirect. He times himself to the meandering, soliloquizing stream; its impulse bears him along. At the foot of the waterfall he sits sequestered and hidden in its volume of sound. The birds know he has no designs upon them, and the animals see that his mind is in the creek. His enthusiasm anneals him and makes him pliable to the scenes and influences he moves among.

Then what acquaintance he makes with the stream! He addresses himself to it as a lover to his mistress; he wooes it and stays with it till he knows its most hidden secrets. It runs through his thoughts not less than through its banks there; he feels the fret and thrust of every bar and bowlder. Where it deepens, his purpose deepens; where it is shallow he is indifferent. He knows how to interpret its every glance and dimple; its beauty haunts him for days.

I am sure I run no risk of overpraising the charm and attractiveness of a well-fed trout stream, every drop of water in it as bright and pure as if the nymphs had brought it all the way from its source in crystal goblets, and as cool as if it had been hatched beneath a glacier. When the heated and soiled and jaded refugee from the city first sees one, 
ho feels as if he would like to turn it into his bosom and let it flow through him a few hours, it suggests such healing freshness and newness. How his roily thuughts would run clear; how the sediment would go down-stream! Could he ever have an impure or an unwholesome wish afterward? The next best thing he can do is to tramp along its banks and surrender himself to its influence. If he reads it intently enough, he will, in a measure, be taking it into his mind and heart, and experiencing its salutary ministrations.

Trout streams coursed through every valley my boyhood knew. I crossed them, and was often lured and detained by them, on my way to and from school. We bathed in them during the long summer noons, and felt for the trout under their banks. A holiday was a holiday indeed that brought permission to go fishing over on Rose's Brook, or up Hardscrabble, or in Meeker's Hollow; all-day trips, from morning till night, through meadows and pastures and beechen woods, wherever the shy, limpid stream led. What an appetite it developed! a hunger that was fierce and aboriginal, and that the wild strawberries we plucked as we crossed the hill teased rather than allayed. When but a few hours could be had, gained perhaps by doing some piece of work about the farm or garden in half the allotted time, the little creek that headed in the paternal domain was handy; when half a day was at one's disposal, there were the hemlocks, less than a mile distant, with their loitering, meditative, log-impeded stream 
and their dusky, fragrant depths. Alert and wideeyed, one picked his way along, startled now and then by the sudden bursting-up of the partridge, or by the whistling wings of the "dropping snipe," pressing through the brush and the briers, or finding ar easy passage over the trunk of a prostrate tree, carefully letting his hook down through some tangle into a still pool, or standing in some high sombre avenue and watching his line float in and out amid the mosscovered bowlders. In my first essayings I used to go to the edge of these hemlocks, seldom dipping into them beyond the first pool where the stream swept under the roots of two large trees. From this point I could look back into the sunlit fields where the cattle were grazing; beyond, all was gloom and mystery; the trout were black, and to my young imagination the silence and the shadows were blacker. But gradually I yielded to the fascination and penetrated the woods farther and farther on each expedition, till the heart of the mystery was fairly plucked out. During the second or third year of my piscatorial experience I went through them, and through the pasture and meadow beyond, and through another strip of hemlocks, to where the little stream joined the main creek of the valley.

In June, when my trout fever ran pretty high, and an auspicious day arrived, I would make a trip to a stream a couple of miles distant, that came down out of a comparatively new settlement. It was a rapid mountain brook presenting many difficult problems to the young angler, but a very enticing stream 
for all that, with its two saw-mill dams, its pretty cascades, its high, shelving rocks sheltering the mossy nests of the phœbe-bird, and its general wild and forbiclling aspects.

But a meadow brook was always a favorite. The trout like meadows; doubtless their food is more abundant there, and, usually, the good hiding-places are more numerous. As soon as you strike a meadow the character of the creek changes: it goes slower and lies deeper; it tarries to enjoy the high, cool banks and to half hide beneath them; it loves the willows, or rather the willows love it and shelter it from the sun; its spring runs are kept cool by the overhanging grass, and the heavy turf that faces its open banks is not cut away by the sharp hoofs of the grazing cattle. Then there are the bobolinks and starlings and meadowlarks, always interested spectators of the angler; there are also the marsh marigolds, the buttercups, or the spotted lilies, and the good angler is always an interested spectator of them. In fact, the patches of meadow land that lie in the angler's course are like the happy experiences in his own life, or like the fine passages in the poem he is reading; the pasture oftener contains the shallow and monotonous places. In the small streams the cattle scare the fish, and soil their element and break down their retreats under the banks. Woodland alternates the best with meadow: the creek loves to burrow under the roots of a great tree, to scoop out a pool after leaping over the prostrate trunk of one, and to pause at the foot of a ledge of moss. 
covered rocks, with ice-cold water dripping down. How straight the current goes for the rock! Note its corrugated, muscular appearance; it strikes and glances off, but accumulates, deepens with welldefined eddies above and to one side; on the edge of these the trout lurk and spring upon their prey.

The angler learns that it is generally some obstacle or hindrance that makes a deep place in the creek, as in a brave life; and his ideal brook is one that lies in deep, well-defined banks, yet makes many a shift from right to left, meets with many rebuffs and adventures, hurled back upon itself by rocks, waylaid by snags and trees, tripped up by precipices, but cooner or later reposing under meadow banks, deepening and eddying beneath bridges, or prosperous and strong in some level stretch of cultivated land with great elms shading it here and there.

But I early learned that from almost any stream in a trout country the true angler could take trout, and that the great secret was this, that, whatever bait you used, worm, grasshopper, grub, or fly, there was one thing you must always put upon your hook, namely, your heart: when you bait your hook with your heart the fish always bite; they will jump clear from the water after it; they will dispute with each other over it; it is a morsel they love above everything else. With such bait I have seen the born angler (my grandfather was one) take a noble string of trout from the most unpromising waters, and on the most unpromising day. He used his hook so coyly and tenderly, he approached the fish with such 
address and insinuation, he divined the exact spot where they lay: if they were not eager he humored them and seemed to steal by them; if they were playful and coquettish he would suit his mood to theirs; if they were frank and sincere he met them half way; he was so patient and considerate, so entirely devoted to pleasing the critical trout, and so successful in his efforts, - surely his heart was upon his hook, and it was a tender, unctuous heart, too, as that of every angler is. How nicely he would measure the distance! how dexterously he would avoid an overhanging limb or bush and drop the line exactly in the right spot! Of course there was a pulse of feeling and sympathy to the extremity of that line. If your heart is a stone, however, or an empty husk, there is no use to put it upon your hook; it will not tempt the fish; the bait must be quick and fresh. Indeed, a certain quality of youth is indispensable to the successful angler, a certain unworldliness and readiness to invest yourself in an enterprise that does n't pay in the current coin. Not only is the angler, like the poet, born and not made, as Walton says, but there is a deal of the poet in him, and he is to be judged no more harshly; he is the victim of his genius: those wild streams, how they haunt him! he will play truant to dull care, and fleo to them; their waters impart somewhat of their own perpetual youth to him. My grandfather when he was eighty years old would take down his pole as eagerly as any boy, and step off with wonderful elasticity toward the beloved streams; it used to try 
my young legs a good deal to follow him, specially on the return trip. And no poet was ever more innocent of worldly success or ambition. For, to paraphrase Tennyson, -

"Lusty tront to him were scrip and share, And babbling waters more than cent for cent."

He laid up treasures, but they were not in this world. In fact, though the kindest of husbands, I fear he was not what the country people call a "good provider," except in providing trout in their season, though it is doubtful if there was always fat in the house to fry them in. But he could tell you they were worse off than that at Valley Forge, and that trout, or any other fish, were good roasted in the ashes under the coals. He had the Walton requisite of loving quietness and contemplation, and was devout withal. Indeed, in many ways he was akin to those Galilee fishermen who were called to be fishers of men. How he read the Book and pored over it, even at times, I suspect, nodding over it, and laying it down only to take up his rod, over which, unless the trout were very dilatory and the journey very fatiguing, he never nodded!

\section{II}

The Delaware is one of our minor rivers, but it is a stream beloved of the trout. Nearly all its remote branches head in mountain springs, and its collected waters, even when warmed by the summer sun, are as sweet and wholesome as dew swept from the grass. The Hudson wins from it two streams that are 
fathered by the mountains from whose loins most of its beginnings issue, namely, the Rondout and the Esopus. These swell a more illustrious current than the Delaware, but the Rondout, one of the finest trout streams in the world, makes an uncanny alliance before it reaches its destination, namely, with the malarious Wallkill.

In the same nest of mountains from which they start are born the Neversink and the Beaverkill, streams of wondrous beauty that flow south and west into the Delaware. From my native hills I could catch glimpses of the mountains in whose laps these creeks were cradled, but it was not till after many years, and after dwelling in a country where trout are not found, that I returned to pay my respects to them as an angler.

My first acquaintance with the Neversink was made in company with some friends in 1869 . We passed up the valley of the Big Ingin, marveling at its copious ice-cold springs, and its immense sweep of heavy-timbered mountain sides. Crossing the range at its head, we struck the Neversink quite unexpectedly about the middle of the afternoon, at a point where it was a good-sized trout stream. It proved to be one of those black mountain brooks born of innumerable ice-cold springs, nourished in the shade, and shod, as it were, with thick-matted moss, that every camper-out remembers. The fish are as black as the stream and very wild. They dart from beneath the fringed rocks, or dive with the hook into the dusky depths, - an integral part of 
the silence and the shadows. The spell of the moss is over all. The fisherman's tread is noiseless, as he leaps from stone to stone and from ledge to ledge along the bed of the stream. How cool it is! He looks up the dark, silent defile, hears the solitary voice of the water, sees the decayed trunks of fallen trees bridging the stream, and all he has dreamed, when a boy, of the haunts of beasts of prey - the crouching feline tribes, especially if it be near nightfall and the gloom already deepening in the woods - comes freshly to mind, and he presses on, wary and alert, and speaking to his companions in low tones.

After an hour or so the trout became less abundant, and with nearly a hundred of the black sprites in our baskets we turned back. Here and there I saw the abandoned nests of the pigeons, sometimes half a dozen in one tree. In a yellow birch which the floods had uprooted, a number of nests were still in place, little shelves or platforms of twigs loosely arranged, and affording little or no protection to the eggs or the young birds against inclement weather.

Before we had reached our companions the rain set in again and forced us to take shelter under a balsam. When it slackened we moved on and soon tame up with Aaron, who had caught his first trout, and, considerably drenched, was making his way toward camp, which one of the party had gone forward to build. After traveling less than a mile, we saw a smoke struggling up through the dripping trees, and in a few moments were all standing round a 
blazing fire. But the rain now commenced again, and fairly poured down through the trees, rendering the prospect of cooking and eating our supper there in the woods, and of passing the night on the ground without tent or cover of any kind, rather disheartening. We had been told of a bark shanty a couple of miles farther down the creek, and thitherward we speedily took up our line of march. When we were on the point of discontinuing the search, thinking we had been misinformed or had passed it by, we came in sight of a barkpeeling, in the midst of which a small log house lifted its naked rafters toward the now breaking sky. It had neither floor nor roof, and was less inviting on first sight than the open woods. But a board partition was still standing, out of which we built a rude porch on the east side of the house, large enough for us all to sleep under if well packed, and eat under if we stood up. There was plenty of well-seasoned timber lying about, and a fire was soon burning in front of our quarters that made the scene social and picturesque, especially when the frying-pans were brought into requisition, and the coffee, in charge of Aaron, who was an artist in this line, mingled its aroma with the wild-wood air. At dusk a balsam was felled, and the tips of the branches used to make a bed, which was more fragrant than soft; hemlock is better, because its needles are finer and its branches more elastic.

There was a spirt or two of rain during the night, but not enough to find out the leaks in our roof. It took the shower or series of showers of the next day 
to do that. They commenced about two o'clock in the afternoon. The forenoon had been fine, and we had brought into camp nearly three hundred trout; but before they were half dressed, or the first panfuls fried, the rain set in. First came short, sharp dashes, then a gleam of treacherous sunshine, followed by more and heavier dashes. The wind was in the southwest, and to rain seerned the easiest thing in the world. From fitful dashes to a steady pour the transition was natural. We stood huddled together, stark and grim, under our cover, like hens under a cart. The fire fought bravely for a time, and retaliated with sparks and spiteful tongues of flame; but gradually its spirit was broken, only a heavy body of coal and half-consumed logs in the centre holding out against all odds. The simmering fish were soon floating about in a yellow liquid that did not look in the least appetizing. Point after point gave way in our cover, till standing between the drops was no longer possible. The water coursed down the underside of the boards, and dripped in our necks and formed puddles on our hat-brims. We shifted our guns and traps and viands, till there was no longer any choice of position, when the loaves and the fishes, the salt and the sugar, the pork and the butter, shared the same watery fate. The fire was gasping its last. Little rivulets coursed about it, and bore away the quenched but steaming coals on their bosoms. The spring run in the rear of our camp swelled so rapidly that part of the trout that bad been hastily left lying on its banks again found 
themselves quite at home. For over two hours the floods came down. About four o'clock Orville, who had not yet come from the day's sport, appeared. To say Orville was wet is not much; he was better than that, - he had been washed and rinsed in at least half a dozen waters, and the trout that he bore dangling at the end of a string hardly knew that they had been out of their proper element.

But he brought welcome news. He had been two or three miles down the creek, and had seen a log building, - whether house or stable he did not know, but it had the appearance of having a good roof, which was inducement enough for us instantly to leave our present quarters. Our course lay along an old wood-road, and much of the time we were to our knees in water. The woods were literally flooded everywhere. Every little rill and springlet ran like a mill-tail, while the main stream rushed and roared, foaming, leaping, lashing, its volume increased fifty fold. The water was not roily, but of a rich coffeecolor, from the leachings of the woods. No more trout for the next three days! we thought as we looked upon the rampant stream.

After we had labored and floundered along for about an hour, the road turned to the left, and in a little stumpy clearing near the creek a gable uprose on our view. It did not prove to be just such a pace as poets love to contemplate. It required a greater effort of the imagination than any of us were then capable of to believe it had ever been a favorite resort of wood-nymphs or sylvan deities. 
It savored rather of the equine and the bovine. The bark-men had kept their teams there, horses on the one side and oxen on the other, and no Hercules had ever done duty in cleansing the stables. But there was a dry loft overhead with some straw, where we might get some sleep, in spite of the rain and the midges; a double layer of boards, standing at a very acute angle, would keep off the former, while the mingled refuse hay and muck beneath would nurse a smoke that would prove a thorough protection against the latter. And then, when Jim, the two-handed, mounting the trunk of a prostrate maple near by, had severed it thrice with easy and familiar stroke, and, rolling the logs in front of the shanty, had kindled a fire, which, getting the better of the dampness, soon cast a bright glow over all, shedding warmth and light even into the dingy stable, I consented to unsling my knapsack and accept the situation. The rain had ceased and the sun shone out behind the woods. We had trout sufficient for present needs; and after my first meal in an ox-stall, I strolled out on the rude log bridge to watch the angry Neversink rush by. Its waters fell quite as rapidly as they rose, and before sundown it looked as if we might have fishing again on the morrow. We had better sleep that night than either night before, though there were two disturbing causes, the smoke in the early part of it, and the cold in the latter. The "no-see-ems" left in disgust; and, though disgusted myself, I swallowed the smoke as best I could, and hugged my pallet of straw the 
eloser. But the day dawned bright, and a plunge in the Neversink set me all right again. The creek, to our surprise and gratification, was only a little higher than before the rain, and some of the finest trout we had yet seen we caught that morning near camp.

We tarried yet another day and night at the old stable, but taking our meals outside squatted on the ground, which had now become quite dry. Part of the day I spent strolling about the woods, looking up old acquaintances among the birds, and, as always, half expectant of making some new ones. Curiously enough, the most abundant species were among those I had found rare in most other localities, namely, the small water-wagtail, the mourning ground warbler, and the yellow-bellied woodpecker. The latter seems to be the prevailing woodpecker through the woods of this region.

That night the midges, those motes that sting, held high carnival. We learned afterward, in the settlement below and from the barkpeelers, that it was the worst night ever experienced in that valley. We had done no fishing during the day, but had anticipated some fine sport about sundown. Accordingly Aaron and I started off between six and seven o'clock, one going up stream and the other down. The scene was charming. The sun shot up great spokes of light from behind the woods, and beauty, like a presence, pervaded the atmosphere. But torment, multiplied as the sands of the seashore, lurked in every tangle and thicket. In a thoughtless mo- 
ment I removed my shoes and socks, and waded in the water to secure a fine trout that had accidentally slipped from my string and was helplessly floating with the current. This caused some delay and gave the gnats time to accumulate. Before I had got one foot half dressed I was enveloped in a black mist that settled upon my hands and neck and face, filling my ears with infinitesimal pipings and covering my flesh with infinitesimal bitings. I thought I should have to flee to the friendly fumes of the old stable, with "one stocking off and one stocking on;" but I got my shoe on at last, though not without many amusing interruptions and digressions.

In a few moments after this adventure $I$ was in rapid retreat toward camp. Just as I reached the path leading from the shanty to the creek, my companion in the same ignoble flight reached it also, his hat broken and rumpled, and his sanguine countenance looking more sanguinary than I had ever before seen it, and his speech, also, in the highest degree inflammatory. His face and forehead were as blotched and swollen as if he had just run his head into a hornets' nest, and his manner as precipitate as if the whole swarm was still at his back.

No smoke or smudge which we ourselves could endure was sufficient in the earlier part of that evening to prevent serious annoyance from the same cause; but later a respite was granted us.

About ten o'clock, as we stood round our campfire, we were startled by a brief but striking display of the aurora borealis. My imagination had already 
been excited by talk of legends and of weird shapes and appearances, and when, on looking up toward the sky, I saw those pale, phantasmal waves of magnetic light chasing each other across the little opening above our heads, and at first sight seeming barely to clear the treetops, I was as vividly impressed as if I had caught a glimpse of a veritable spectre of the Neversink. The sky shook and trembled like a great white curtain.

After we had climbed to our loft and had lain down to sleep, another adventure befell us. This time a new and uninviting customer appeared upon the scene, the genius loci of the old stable, namely, the "fretful porcupine." We had seen the marks and work of these animals about the shanty, and had been careful each night to hang our traps, guns, etc., beyond their reach, but of the prickly nightwalker himself we feared we should not get a view.

We had lain down some half hour, and I was just on the threshold of sleep, ready, as it were, to pass through the open door into the land of dreams, when I heard outside somewhere that curious sound, - a sound which I had heard every night I spent in these woods, not only on this but on former expeditions, and which I had settled in my mind as proceeding from the porcupine, since I knew the sounds our other common animals were likely to make, - a sound that might be either a gnawing on some hard, dry substance, or a grating of teeth, or a shrill grunting.

Orville heard it also, and, raising up on his elbow asked, "What is that?" 
"What the hunters call a "porcupig," " said I. "Sure?"

"Entirely so."

"Why does he make that noise?"

"It is a way he has of cursing our fire," I replied. "I heard him last night also."

"Where do you suppose he is?" inquired my companion, showing a disposition to look him up.

"Not far off, perhaps fifteen or twenty yards from our fire, where the shadows begin to deepen."

Orville slipped into his trousers, felt for my gun, and in a moment had disappeared down through the scuttle hole. I had no disposition to follow him, but was rather annoyed than otherwise at the disturbance. Getting the direction of the sound, he went picking his way over the rough, uneven ground, and, when he got where the light failed him, poking every doubtful object with the end of his gun. Presently he poked a light grayish object, like a large round stone, which surprised him by moving off. On this hint he fired, making an incurable wound in the "porcupig," which, nevertheless, tried harder than ever to escape. I lay listening, when, close on the heels of the report of the gun, came excited shouts for a revolver. Snatching up my Smith and Wesson, I hastened, shoeless and hatless, to the scene of action, wondering what was up. I found my companion struggling to detain, with the end of the gun, an uncertain object that was trying to crawl off into the darkness. "Look out!" said Orville, as he saw my bare feet, "the quills are lying thick around here." 
And sc they were; he had blown or beaten them nearly all off the poor creature's back, and was in a fair way completely to disable my gun, the rarnrod of which was already broken and splintered clubbing his victim. But a couple of shots from the revolver, sighted by a lighted match, at the head of the animal, quickly settled him.

It proved to be an unusually large Canada porcupine, - an old patriarch, gray and venerable, with spines three inches long, and weighing, I should say, twenty pounds. The build of this animal is much like that of the woodchuck, that is, heavy and pouchy. The nose is blunter than that of the woodchuck, the limbs stronger, and the tail broader and heavier. Indeed, the latter appendage is quite clublike, and the animal can, no doubt, deal a smart blow with it. An old hunter with whom I talked thought it aided them in climbing. They are inveterate gnawers, and spend much of their time in trees gnawing the bark. In winter one will take up its abode in a hemlock, and continue there till the tree is quite denuded. The carcass emitted a peculiar offensive odor, and, though very fat, was not in the least inviting as game. If it is part of the economy of nature for one animal to prey upon some other beneath it, then the poor devil has indeed a mouthful that makes a ineal off the porcupine. Panthers and lynxes have essayed it, but have invariably left off at the first course, and have afterwards been found dead, or nearly so, with their heads puffed up like a pincushion, and the quills 
protruding on all sides. A dog that understands the business will manœuvre round the porcupine till he gets an opportunity to throw it over on its back, when he fastens on its quilless underbody. Aaron was puzzled to know how long-parted friends could embrace, when it was suggested that the quills could be depressed or elevated at pleasure.

The next morning boded rain; but we had become thoroughly sated with the delights of our present quarters, outside and in, and packed up our traps to leave. Before we had reached the clearing, three miles below, the rain set in, keeping up a lazy, monotonous drizzle till the afternoon.

The clearing was quite a recent one, made mostly by barkpeelers, who followed their calling in the mountains round about in summer, and worked in their shops making shingle in winter. The Biscuit Brook came in here from the west, - a fine, rapid trout stream six or eight miles in length, with plenty of deer in the mountains about its head. On its banks we found the house of an old woodman, to whom we had been directed for information about the section we proposed to traverse.

"Is the way very difficult," we inquired, "across from the Neversink into the head of the Beaverkill ?"

"Not to me; I could go it the darkest night ever was. And I can direct you so you can find the way without any trouble. You go down the Neversink about a mile, when you come to Highfall Brook, the first stream that comes down on the right. Fol 
low up it to Jim Reed's shanty, about three miles. Then cross the stream, and on the left bank, pretty well up on the side of the mountain, you will find a wood-road, which was made by a fellow below her who stole some ash logs off the top of the ridge last winter and drew them out on the snow. When the road first begins to tilt over the mountain, strike down to your left, and you can reach the Beaverkill before sundown."

As it was then after two o'clock, and as the distance was six or eight of these terrible hunters' miles, we concluded to take a whole day to it, and wait till next morning. The Beaverkill flowed west, the Neversink south, and I had a mortal dread of getting entangled amid the mountains and valleys that lie in either angle.

Besides, I was glad of another and final opportunity to pay my respects to the finny tribes of the Neversink. At this point it was one of the finest trout streams I had ever beheld. It was so sparkling, its bed so free from sediment or impurities of any kind, that it had a new look, as if it had just come from the hand of its Creator. I tramped along - its margin upward of a mile that afternoon, part of the time wading to my knees, and casting my hook, baited only with a trout's fin, to the opposite bank. Trout are real cannibals, and make no bones, and break none either, in lunching on each other. A friend of mine had several in his spring, when one day a large female trout gulped down one of her male friends, nearly one third hrr own size, and went 
around for two days with the tail of her liege lord protruding from her mouth! A fish's eye will do for bait, though the anal fin is better. One of the natives here told me that when he wished to catch large trout (and I judged he never fished for any other, - I never do), he used for bait the bullhead, or dart, a little fish an inch and a half or two inches long, that rests on the pebbles near shore and darts quickly, when disturbed, from point to point. "Put that on your hook," said he, "and if there is a big fish in the creek he is bound to have it." But the darts were not easily found; the big fish, I concluded, had cleaned them all out; and, then, it was easy enough to supply our wants with a fin.

Declining the hospitable offers of the settlers, wo spread our blankets that night in a dilapidated shingle-shop on the banks of the Biscuit Brook, first flooring the damp ground with the new shingle that lay piled in one corner. The place had a greatthroated chimney with a tremendous expanse of fireplace within, that cried "More!" at every morsel of wood we gave it.

But I must hasten over this part of the ground, nor let the delicious flavor of the milk we had that morning for breakfast, and that was so delectable after four days of fish, linger on my tongue; nor yet tarry to set down the talk of that honest, weatherworn passer-by who paused before our door, and every moment on the point of resuming his way, yet stood for an hour and recited his adventures hunting deer and bears on these mountains. Having 
replenished our stock of bread and salt pork at tho house of one of the settlers, midday found us at Reed's shanty, - one of those temporary structures erected by the bark jobber to lodge and board his "hands" near their work. Jim not being at home, we could gain no information from the "women folks" about the way, nor from the men who had just come in to dinner; so we pushed on, as near as we could, according to the instructions we had previously received. Crossing the creek, we forced our way up the side of the mountain, through a perfect cheval-de-firise of fallen and peeled hemlocks, and, entering the dense woods above, began to look anxiously about for the wood-road. My companions at first could see no trace of it; but knowing that a casual wood-road eut in winter, when there was likely to be two or three feet of snow on the ground, would present only the slightest indications to the eye in summer, I looked a little closer, and could make out a mark or two here and there. The larger trees had been avoided, and the axe used only on the small saplings and underbrush, which had been lopped off a couple of feet from the ground. By being constantly on the alert, we followed it till near the top of the mountain; but, when looking to see it "tilt" over the other side, it disappeared altogether. Some stumps of the black cherry were found, and a solitary pair of snow-shoes were hanging high and dry on a branch, but no further trace of human hands could we see. While we were resting here a couple of hermit thrushes, one of them with some sad defect 
in his vocal powers which barred him from uttering more than a few notes of his song, gave voice to the solitude of the place. This was the second instance in which I have observed a song-bird with apparently some organic defect in its instrument. The other case was that of a bobolink, which, hover in midair and inflate its throat as it might, could only force out a few incoherent notes. But the bird in each case presented this striking contrast to human examples of the kind, that it was apparently just as proud of itself, and just as well satisfied with its performance, as its more successful rivals.

After deliberating some time over a pocket compass which I carried, we decided upon our course, and held on to the west. The descent was very gradual. Traces of bear and deer were noted at different points, but not a live animal was seen.

About four o'clock we reached the bank of a stream flowing west. Hail to the Beaverkill! and we pushed on along its banks. The trout were plenty, and rose quickly to the hook; but we held on our way, designing to go into camp about six o'clock. Many inviting places, first on one bank, then on the other, made us linger, till finally we reached a smooth, dry place overshadowed by balsam and hemlock, where the creek bent around a little flat, which was so entirely to our fancy that we unslung our knapsacks at once. While my companions were cutting wood and making other preparations for the night, it fell to my lot, as the most successful angler, to provide the trout for supper and breakfast. 
How shall I describe that wild, beautiful strean, with features so like those of all other mountain streams? And yet, as I saw it in the deep twilight of those woods on that June afternoon, with its steady, even flow, and its tranquil, many-voiced murmur, it made an impression upon my mind distinet and peculiar, fraught in an eminent degree with the eharm of seclusion and remoteness. The solitude was perfect, and I felt that strangeness and insignificance which the civilized man must always feel when opposing himself to such a vast scene of silence and wildness. The trout were quite black, like all wood trout, and took the bait eagerly. I followed the stream till the deepening shadows warned me to turn back. As I neared camp, the fire shone far through the trees, dispelling the gathering gloom, but blinding my eyes to all obstacles at my feet. I was seriously disturbed on arriving to find that one of my companions had cut an ugly gash in his shin with the axe while felling a tree. As we did not carry a fifth wheel, it was not just the time or place to have any of our members crippled, and I had bodings of evil. But, thanks to the healing virtues of the balsam which must have adhered to the blade of the axe, and double thanks to the court-plaster with which Orville had supplied himself before leaving home, the wounded leg, by being favored that night and the next day, gave us little trouble.

That night we had our first fair and square camping out, - that is, sleeping on the ground with no 
shelter over us but the trees, - and it was in many respects the pleasantest night we spent in the woods. The weather was perfect and the place was perfect, and for the first time we were exempt from the midges and smoke; and then we appreciated the clean new page we had to work on. Nothing is so acceptable to the camper-out as a pure article in the way of woods and waters. Any admixture of human relics mars the spirit of the scene. Yet I am willing to confess that, before we were through those woods, the marks of an axe in a tree was a welcome sight. On resuming our march next day we followed the right , bank of the Beaverkill, in order to strike a stream which flowed in from the north, and which was the outlet of Balsam Lake, the objective point of that day's march. The distance to the lake from our camp could not have been over six or seven miles; yet, traveling as we did, without path or guide, climbing up banks, plunging into ravines, making detours around swampy places, and forcing our way through woods choked up with much fallen and decayed timber, it seemed at least twice that distance, and the mid-afternoon sun was shining when we emerged into what is called the "Quaker Clearing," ground that I had been over nine years before, and that lies about two miles south of the lake. From this point we had a well-worn path that led us up a sharp rise of ground, then through level woods till we saw the bright gleam of the water through the trees.

I am always struck, on approaching these little 
mountain lakes, with the extensive preparation that is made for them in the conformation of the ground. I am thinking of a depression, or natural basin, in the side of the mountain or on its top, the brink of which I shall reach after a little steep climbing; but instead of that, after I have accomplished the ascent, I find a broad sweep of level or gently undulating woodland that brings me after a half hour or so to the lake, which lies in this vast lap like a drop of water in the palm of a man's hand.

Balsam Lake was oval-shaped, scarcely more than half a mile long and a quarter of a mile wide, but presented a charming picture, with a group of dark gray hemlocks filling the valley about its head, and the mountains rising above and beyond. We found a bough house in good repair, also a dug-out and paddle and several floats of logs. In the dug-out I was soon creeping along the shady side of the lake, where the trout were incessantly jumping for a species of black fly, that, sheltered from the slight breeze, were dancing in swarms just above the surface of the water. The gnats were there in swarms also, and did their best toward balancing the accounts by preying upon me while I preyed upon the trout which preyed upon the flies. But by dint of keeping my hands, face, and neck constantly wet, I am convinced that the balance of blood was on $m y$ side. The trout jumped most within a foot or two of shore, where the water was only a fow inches deep. The shallowness of the water, perhaps, accounted for the inability of the fish to do more than 
lift their heads above the surface. They came up mouth wide open, and dropped back again in the most impotent manner. Where there is any depth of water, a trout will jump several feet into the air; and where there is a solid, unbroken sheet or column, they will scale falls and dams fifteen feet high.

We had the very cream and flower of our troutfishing at this lake. For the first time we could use the fly to advantage; and then the contrast between laborious tramping along shore, on the one hand, and sitting in one end of a dug-out and casting your line right and left with no fear of entanglement in brush or branch, while you were gently propelled along, on the other, was of the most pleasing character.

There were two varieties of trout in the lake, what it seems proper to call silver trout and golden trout; the former were the slimmer, and seemed to keep apart from the latter. Starting from the outlet and working round on the eastern side toward the head, we invariably caught these first. They glanced in the sun like bars of silver. Their sides and bellies were indeed as white as new silver. As we neared the head, and especially as we came near a space occupied by some kind of watergrass that grew in the deeper part of the lake, the other variety would begin to take the hook, their bellies a bright gold color, which became a deep orange on their fins; and as we returned to the place of departure with the bottom of the boat strewn with these bright forms intermingled, it was a sight not soon to be 
forgotten. It pleased my eye so, that I would fain linger over them, arranging them in rows and studying the various hues and tints. They were of nearly a uniform size, rarely one over ten or under eight inches in length, and it seemed as if the hues of all the precious metals and stones were reflected from their sides. The flesh was deep salmon-color; that of brook trout is generally much lighter. Some hunters and fishers from the valley of the Mill Brook, whom we met here, told us the trout were much larger in the lake, though far less numerous than they used to be. Brook-trout do not grow large till they become scarce. It is only in streams that have been long and much fished that I have caught them as much as sixteen inches in length.

The "porcupigs" were numerous about the lake, and not at all shy. One night the heat became so intolerable in our oven-shaped bough house that I was obliged to withdraw from under its cover and lie down a little to one side. Just at daybreak, as I lay rolled in my blanket, something awoke me. Lifting up my head, there was a porcupine with his forepaws on my hips. He was apparently as much surprised as I was; and to my inquiry as to what he at that moment might be looking for, he did not pause to reply, but, hitting me a slap with his tail which left three or four quills in my blanket, he scampered off down the hill into the brush.

Being an observer of the birds, of course every curious incident connected with them fell under my notice. Hence, as we stood about our camp-fire one 
afternoon looking out over the lake, I was the only one to see a little commotion in the water, half hidden by the near branches, as of some tiny swimmer struggling to reach the shore. Rushing to its rescue in the canoe, I found a yellow-rumped warbler, quite exhausted, clinging to a twig that hung down into the water. I brought the drenched and helpless thing to camp, and, putting it into a basket, hung it up to dry. An hour or two afterward I heard it fluttering in its prison, and cautiously lifted the lid to get a better glimpse of the lucky captive, when it darted out and was gone in a twinkling. How came it in the water? That was my wonder, and I can only guess that it was a young bird that had never before flown over a pond of water, and, seeing the clouds and blue sky so perfect down there, thought it was a vast opening or gateway into another summer land, perhaps a short cut to the tropics, and so got itself into trouble. How my eye was delighted also with the redbird that alighted for a moment on a dry branch above the lake, just where a ray of light from the setting sun fell full upon it! A mere crimson point, and yet how it offset that dark, sombre background!

I have thus run over some of the features of an ordinary trouting excursion to the woods. People inexperienced in such matters, sitting in their rooms and thinking of these things, of all the poets have sung and romancers written, are apt to get sadly taken in when they attempt to realize their dreams. 
They expect to enter a sylvan paradise of trout, cool retreats, laughing brooks, picturesque views, bal. samic couches, etc., instead of which they find hunger, rain, smoke, toil, gnats, mosquitoes, dirt, broken rest, vulgar guides, and salt pork; and they are very apt not to see where the fun comes in. But he who goes in a right spirit will not be disappoiuted, and will find the taste of this kind of life better, though. bitterer, than the writers have described. 



\section{VI}

\section{BIRDS AND BIRDS}

\section{I}

THERE is an old legend which one of our poets 1 has made use of about the bird in the brain, a legend based, perhaps, upon the human significance of our feathered neighbors. Was not Audubon's brain full of birds, and very lively ones, too? A person who knew him says he looked like a bird himself; keen, alert, wide-eyed. It is not unusual to see the hawk looking out of the human countenance, and one may see or have seen that still nobler bird, the eagle. The song-birds might all have been brooded and hatched in the human heart. They are typical of its highest aspirations, and nearly the whole gamut of human passion and emotion is expressed more or less fully in their varied songs. Among our own birds, there is the song of the hermit thrush for devoutness and religious serenity; that of the wood thrush for the musing, melodious thoughts of twilight; the song sparrow's for simple faith and trust, the bobolink's for hilarity and glee, the mourning dove's for hopeless sorrow, the vireo's for all-day and every-day contentment, and the nocturne of the mockingbird for love. Then there are 
the plaintive singers, the soaring, ecstatic singers, the confident singers, the gushing and voluble singers, and the half-voiced, inarticulate singers. The note of the wood pewee is a human sigh; the chickadee has a call full of unspeakakle tenderness and fidelity. There is pride in the song of the tanager, and vanity in that of the catbird. There is something distinctly human about the robin; his is the note of boyhood. I have thoughts that follow the migrating fowls northward and southward, and that go wiuh the seabirds into the desert of the ocean, lonely and tireless as they. I sympathize with the watchful crow perched yonder on that tree, or walking about the fields. I hurry outdoors when I hear the clarion of the wild gander; his comrade in my heart sends back the call.

Here comes the cuckoo, the solitary, the joyless, enamored of the privacy of his own thoughts; when did he fly away out of this brain? The cuckoo is one of the famous birds, and is known the world over. $\mathrm{He}$ is mentioned in the Bible, and is discussed by Pliny and Aristotle. Jupiter himself once assumed the form of the cuckoo in order to take advantage of Juno's compassion for the bird.

We have only a reduced and modified cuckoo in this country. Our bird is smaller, and is much more solitary and unsocial. Its color is totally different from the Old World bird, the latter being speckled, or a kind of dominick, while ours is of the finest 
cinnamon-brown or drab above, and bluish white beneath, with a gloss and richness of texture in the plumage that suggests silk. The bird has also mended its manners in this country, and no longer foists its eggs and young upon other birds, but builds a nest of its own and rears its own brood like other well-disposed birds.

The European cuckoo is evidently much more of a spring bird than ours is, much more a harbinger of the early season. He comes in April, while ours seldom appears till late in May, and hardly then appears. He is printed, as they say, but not published. Only the alert ones know he is here. This old English rhyme on the cuckoo does not apply this side the Atlantic: -

$$
\begin{aligned}
& \text { "In April } \\
& \text { Come he will, } \\
& \text { In flow'ry May } \\
& \text { He sings all day, } \\
& \text { In leafy June } \\
& \text { He changes his tune, } \\
& \text { In bright July } \\
& \text { He's ready to fly, } \\
& \text { In August } \\
& \text { Go he must." }
\end{aligned}
$$

Our bird must go in August, too, but at no time does he sing all day. Indeed, his peculiar guttural call has none of the character of a song. It is a solitary, hermit-like sound, as if the bird were alone in the world, and called upon the Fates to witness his desolation. I have never seen two cuckoos together, and I have never heard their call answered; it goes forth into the solitudes unreclaimed. Liko 
a true American, the bird lacks animal spirits and a genius for social intercourse. One August night I heard one calling, calling, a long time, not far from my house. It was a true night sound, more fitting then than by day.

The European cuckoo, on the other hand, seems to be a joyous, vivacious bird. Wordsworth applies to it the adjective "blithe," and says:-

"I hear thee babbling to the vale

Of sunshine and of flowers."

English writers all agree that its song is animated and pleasing, and the outcome of a light heart. Thomas Hardy, whose touches always seem true to nature, describes in one of his books an early summer scene from amid which "the loud notes of three cuckoos were resounding through the still air." This is totally unlike our bird, which does not sing in concert, but affects remote woods, and is most frequently heard in cloudy weather. Hence the name of rain-crow that is applied to him in some parts of the country. I am more than half inclined to believe that his call does indicate rain, as it is certain that of the tree-toad does.

The cuckoo has a slender, long-drawn-out appearance on account of the great length of tail. It is seldom seen about farms or near human habitations until the June canker-worm appears, when it makes frequent visits to the orchard. It loves hairy worms, and has eaten so many of them that its gizzard is lined with hair.

The European cuckoo builds no nest, but puts its 
eggs out to be hatched, as does our cow blackbird, and our cuckoo is master of only the rudiments of nest-building. No other bird in the woods builds so shabby a nest; it is the merest makeshift, - a loose scaffolding of twigs through which the eggs can be seen. One season, I knew of a pair that built within a few feet of a country house that stood in the midst of a grove, but a heavy storm of rain and wind broke up the nest.

If the Old World cuckoo had been as silent and retiring a bird as ours is, it could never have figured so conspicuously in literature as it does, - having a prominence that we would give only to the bobolink or to the wood thrush, - as witness his frequent mention by Shakespeare, or the following early English ballad (in modern guise):-

\author{
"Summer is come in, \\ Loud sings the cuckoo; \\ Groweth seed and bloweth mead, \\ And springs the wood now. \\ Sing, cuckoo; \\ The ewe bleateth for her lamb, \\ The cow loweth for her calf, \\ The bullock starteth. \\ The buck verteth, \\ Merrily sings the cuckoo \\ Cuckoo, cuckoo ; \\ Well sings the cuckoo, \\ Mayest thou never cease."
}

\title{
III
}

I think it will be found, on the whole, that the European birds are a more hardy and pugnacious race than ours, and that their song-birds have more 
vivacity and power, and ours more melody and plaintiveness. In the song of the skylark, for instance, there is little or no melody, but wonderful strength and copiousness. It is a harsh strain near at hand, but very taking when showered down from a height of several hundred feet.

Daines Barrington, the naturalist of the last century, to whom White of Selborne addressed so many of his letters, gives a table of the comparative merit of seventeen leading song-birds of Europe, marking them under the heads of mellowness, sprightliness, plaintiveness, compass and execution. In the aggregate, the songsters stand highest in sprightliness, next in compass and execution, and lowest in the other two qualities. A similar arrangement and comparison of our songsters, I think, would show an opposite result, - that is, a predominance of melody and plaintiveness. The British wren, for instance, stands in Barrington's table as destitute of both these qualities; the reed sparrow also. Our wrensongs, on the contrary, are gushing and lyrical, and more or less melodious, - that of the winter wren being preëminently so. Our sparrows, too, all have sweet, plaintive ditties, with but little sprightliness or compass. The English house sparrow has no song at all, but a harsh chatter that is unmatched among our birds. But what a hardy, prolific, pugnacious little wretch it is! They will maintain themselves where our birds will not live at all, and a pair of them will lie down in the gutter and fight like dogs. Compared with this miniature John Bull, the voice 
and manners of our common sparrow are gentle and retiring. The English sparrow is a street gamin, our bird a timid rustic.

The English robin redbreast is tallied in this country by the bluebird, which was called by the early settlers of New England the blue robin. The song of the British bird is bright and aminated, that of our bird soft and plaintive.

The nightingale stands at the head in Barrington's table, and is but little short of perfect in all the qualities. We have no one bird that combines such strength or vivacity with such melody. The mockingbird doubtless surpasses it in variety and profusion of notes; but falls short, I imagine, in sweetness and effeetiveness. The nightingale will sometimes warble twenty seconds without pausing to breathe, and when the condition of the air is favorable its song fills a space a mile in diameter. There are, perhaps, songs in our woods as mellow and brilliant, as is that of the elosely allied species, the water-thrush; but our bird's song has but a mere fraction of the nightingale's volume and power.

Strength and volume of voice, then, seem to be characteristic of the English birds, and mildness and delicacy of ours. How much the thousands of years of contact with man, and familiarity with artificial sounds, over there, have affected the bird voices, is a question. Certain it is that their birds are much more domestic than ours, and certain it is that all purely wild sounds are plaintive and elusive. Even of the bark of the fox, the cry of the panther, the 
voice of the coon, or the call and clang of wild geese and ducks, or the war-cry of savage tribes, is this true; but not true in the same sense of domesticated or semi-domesticated animals and fowls. How different the voice of the common duck or goose from that of the wild species, or of the tame dove from that of the turtle of the fields and groves! Where could the English house sparrow have acquired that unmusical voice but amid the sounds of hoofs and wheels, and the discords of the street? And the ordinary notes and calls of so many of the British birds, according to their biographers, are harsh and disagreeable; even the nightingale has an ugly, guttural "chuck." The missel-thrush has a harsh scream; the jay a note like "wrack," "wrack;" the fieldfare a rasping chatter; the blackbird, which is our robin cut in ebony, will sometimes crow like a cock and cackle like a hen; the flocks of starlings make a noise like a steam saw-mill; the whitethroat has a disagreeable note; the swift a discordant scream; and the bunting a harsh song. Among our songbirds, on the contrary, it is rare to hear a harsh or displeasing voice. Even their notes of anger and alarm are more or less soft.

I would not imply that our birds are the better songsters, but that their songs, if briefer and feebler, are also more wild and plaintive, - in fact, that they are softer-voiced. The British birds, as I have stated, are more domestic than ours; a much larger number build about houses and towers and outbuildings. The titmouse with us is exclusively a wood- 
bird; but in Britain three or four species of them resort more or less to buildings in winter. Their redstart also builds under the eaves of houses; their starling in church steeples and in holes in walls; several thrushes resort to sheds to nest; and jackdaws breed in the crannies of the old architecture, and this in a much milder climate than our own.

They have in that country no birds that answer to our tiny, lisping wood-warblers, - genus Dendroica, - nor to our vireos, Vireonida. On the other hand, they have a larger number of field-birds and semi-game-birds. They have several species like our robin; thrushes like him, and some of them larger, as the ring ouzel, the missel-thrush, the fieldfare, the throstle, the redwing, White's thrush, the blackbird, - these, besides several species in size and habits more like our wood thrush.

Several species of European birds sing at night besides the true nightingale, - not fitfully and as if in their dreams, as do a few of our birds, but continuously. They make a business of it. The sedgebird ceases at times as if from very weariness; but wake the bird up, says White, by throwing a stick or stone into the bushes, and away it goes again in full song. We have but one real nocturnal songster, and that is the mockingbird. One can see how this habit might increase among the birds of a long-settled country like England. With sounds and voices about them, why should they be silent, too? The danger of betraying themselves to their natural enemies would be less than in our woods. 
That their birds are more quarrelsome and pugna. cious than ours I think evident. Our thrushes are especially mild-mannered, but the missel-thrush is very bold and saucy, and has been known to fly in the face of persons who have disturbed the sitting bird. No jay nor magpie nor crow can stand before him. The Welsh call him master of the coppice, and he welcomes a storm with such a vigorous and hearty song that in some countries he is known as storm-cock. He sometimes kills the young of other birds and eats eggs, - a very unthrushlike trait. The whitethroat sings with crest erect, and attitudes of warning and defiance. The hooper is a great bully; so is the greenfinch. The wood-grousenow extinct, I believe - has been known to attack people in the woods. And behold the grit and hardihood of that little emigrant or exile to our shores, the English sparrow! Our birds have their tilts and spats also; but the only really quarrelsome mem. bers in our family are confined to the flycatchers, as the kingbird and great crested flycatcher. None of our song-birds are bullies.

Many of our more vigorous species, as the butcherbird, the crossbills, the pine grosbeak, the redpoll, the Bohemian chatterer, the shore lark, the longspur, the snow bunting, etc., are common to both continents.

Have the Old World creatures throughout more pluck and hardihood than those that are indigenous to this continent? Behold the common mouse, how he has followed man to this country and established 
himself here against all opposition, overrunning our houses and barns, while the native species is rarely seen. And when has anybody seen the American rat, while his congener from across the water has penetrated to every part of the continent! By the next train that takes the family to some Western frontier, arrives this pest. Both our rat and mouse or mice are timid, harmless, delicate creatures, compared with the cunning, filthy, and prolific specimens that have fought their way to us from the old World. There is little doubt, also, that the red fox has been transplanted to this country from Europe. $\mathrm{He}$ is certainly on the increase, and is fast running out the native gray species.

Indeed, I have thought that all forms of life in the Old World were marked by greater prominence of type, or stronger characteristic and fundamental qualities, than with us, - coarser and more hairy and virile, and therefore more powerful and lasting. This opinion is still subject to revision, but I find it easier to confirm it than to undermine it.

\section{IV}

But let me change the strain and contemplate for a few moments this feathered bandit, - this bird with the mark of Cain upon him, Lanius borealis, - the great shrike or butcher-bird. Usually the character of a bird of prey is well defined; there is no mistaking him. His claws, his beak, his hearl, his wings, in fact his whole build, point to the fact that he subsists upon live creatures; he is armed to 
catch them and to slay them. Every bird knows a hawk and knows him from the start, and is on the lookout for him. The hawk takes life, but he does it to maintain his own, and it is a public and universally known fact. Nature has sent him abroad in that character, and has advised all creatures of it. Not so with the shrike; here she has concealed the character of a murderer under a form as innocent as that of the robin. Feet, wings, tail, color, head, and general form and size are all those of a song-bird, - very much like that master songster, the mockingbird, - yet this bird is a regular Bluebeard among its kind. Its only characteristic feature is its beak, the upper mandible having two sharp processes and a sharp hooked point. It cannot fly away to any distance with the bird it kills, nor hold it in its claws to feed upon it. It usually impales its victim upon a thorn, or thrusts it in the fork of a limb. For the most part, however, its food seems to consist of insects, - spiders, grasshoppers, beetles, etc. It is the assassin of the small birds, whom it often destroys in pure wantonness, or merely to sun on their brains, as the Gaucho slaughters a wild cow or bull for its tongue. It is a wolf in sheep's clothing. Apparently its victims are unacquainted with its true character and allow it to approach them, when the fatal blow is given. I saw an illustration of this the other day. A large number of goldfinches in their fall plumage, together with snowbirds and sparrows, were feeding and chattering in some low bushes back of the barn. I had paused by the fence and was 
peeping through at them, hoping to get a glimpse of that rare sparrow, the white-crowned. Presently I heard a rustling among the dry leaves as if some larger bird was also among them. Then I heard one of the goldfinches cry out as if in distress, when the whole flock of them started up in alarm, and, circling around, settled in the tops of the larger trees. I continued my scrutiny of the bushes, when I saw a large bird, with some object in its beak, hopping aiong on a low branch near the ground. It disappeared from my sight for a few moments, then came up through the undergrowth inte the top of a young maple where some of the finches had alighted, and I beheld the shrike. The little birds avoided him and flew about the tree, their pursuer following them with the motions of his head and body as if he would fain arrest them by his murderous gaze. The birds did not utter the cry or make the demonstration of alarm they usually do on the appearance of a hawk, but chirruped and called and flew about in a halfwondering, half-bewildered manner. As they flew farther along the line of trees the shrike followed them as if bent on further captures. I then made my way around to see what the shrike had caught, and what he had done with his prey. As I approached the bushes I saw the shrike hastening back. I read his intentions at once. Seeing my movements, he had returned for his game. But I was too quick for him, and he got up out of the brush and flew away from the locality. On some twigs in the thickest part of the bushes I found his 
victim, - a goldfinch. It was not impaled upon a thorn, but was carefully disposed upon some horizontal twigs, - laid upon the shelf, so to speak. It was as warm as in life, and its plumage was unruffled. On examining it I found a large bruise or break in the skin on the back of the neck, at the base of the skull. Here the bandit had no doubt griped the bird with his strong beak. The shrike's bloodthirstiness was seen in the fact that it did not stop to devour its prey, but went in quest of more, as if opening a market of goldfinches. The thicket was his shambles, and if not interrupted he might have had a fine display of tidbits in a short time.

The shrike is called a butcher from his habit of sticking his meat upon hooks and points; further than that, he is a butcher because he devours but a trifle of what he slays.

A few days before, I had witnessed another little scene in which the shrike was the chief actor. A chipmunk had his den in the side of the terrace above the garden, and spent the mornings laying in a store of corn which he stole from a field ten or twelve rods away. In traversing about half this distance, the little poacher was exposed; the first cover going from his den was a large maple, where he always brought up and took a survey of the scene. I would see him spinning along toward the maple, then from it by an easy stage to the fence adjoining the corn; then back again with his booty. One morning I paused to watch him more at my leisure. He came up out of his retreat and cocked himself 
np to see what my motions meant. His forepaws were clasped to his breast precisely as if they had been hands, and the tips of the fingers thrust inta his vest pockets. Having satisfied himself with reference to me, he sped on toward the tree. He had nearly reached it, when he turned tail and rushed for his hole with the greatest precipitation. As he neared it, I saw some bluish object in the air closing in upon him with the speed of an arrow, and, as he vanished within, a shrike brought up in front of the spot, and with spread wings and tail stood hovering a moment, and, looking in, then turned and went away. Apparently it was a narrow escape for the chipmunk, and, I venture to say, he stole no more corn that morning. The shrike is said to catch mice, but it is not known to attack squirrels. He certainly could not have strangled the chipmunk, and I am curious to know what would have been the result had he overtaken him. Probably it was only a kind of brag on the part of the bird, - a bold dash where no risk was run. He simulated the hawk, the squirrel's real enemy, and no doubt enjoyed the joke.

On another occasion, as I was riding along a mountain road early in April, a bird started from the fence where I was passing, and flew heavily to the branch of a near apple-tree. It proved to be a shrike with a small bird in his beak. He thrust his rictim into a fork of a branch, then wiped his bloody beak upon the bark. A youth who was with me, to whom I pointed out the fact, had never heard of such a thing, and was much incensed at the shrike. "Let 
me fire a stone at him," said he, and jumping out of the wagon he pulled off his mittens, and fumbled about for a stone. Having found one to his liking, with great earnestness and deliberation he let drive. The bird was in more danger than I had imagined, for he escaped only by a hair's breadth; a guiltless bird like the robin or sparrow would surely have been slain; the missile grazed the spot where the shrike sat, and cut the ends of his wings as he darted behind the branch. We could see that the murdered bird had been brained, as its head hung down toward us.

The shrike is not a summer bird with us in the Northern States, but mainly a fall and winter one; in summer he goes farther north. I see him most freanently in November and December. I recall a morning during the former month that was singularly clear and motionless; the air was like a great drum. Apparently every sound within the compass of the horizon was distinctly heard. The explosions back in the cement quarries ten miles away smote the hollow and reverberating air like giant fists. Just as the sun first showed his fiery brow above the horizon, a gun was discharged over the river. On the instant a shrike, perched on the topmost spray of a maple above the house, set up a loud, harsh call or whistle, suggestive of certain notes of the blue jay. The note presently became a crude, broken warble. Even this scalper of the innocents had music in his soul on such a morning. He saluted the sun as a robin might have done. After he had finished ho flew away toward the east. 
The shrike is a citizen of the world, being found in both hemispheres. It does not appear that the European speeies differs essentially from our own. In Germany he is called the nine-killer, from the belief that he kills and sticks upon thorns nine grasshoppers a day.

To make my portrait of the shrike more complete, I will add another trait of him described by an acute observer who writes me from western New York. $\mathrm{He}$ saw the bird on a bright midwinter morning when the thermometer stood at zero, and by cautious approaches succeeded in getting under the apple-tree upon which he was perched. The shrike was uttering a loud, clear note like clu-eet, clu-eet, clu-eet, and, on finding he had a listener who was attentive and curious, varied his performance and kept it up continuously for fifteen minutes. He seemed to enjoy having a spectator, and never took his eye off him. The observer approached within twenty feet of him. "As I came near," he says, "the shrike began to scold at me, a sharp, buzzing, squeaking sound not easy to describe. After a little he came out on the end of the limb nearest me, then he posed himself, and, opening his wings a little, began to trill and warble under his breath, as it were, with an occasional squeak, and vibrating his half-open wings in time with his song." Some of his notes resembled those of the bluebird, and the whole performance is described as pleasing and melodious.

This account agrees with Thoreau's observation, where he speaks of the shrike "with heedless and 
unfrozen melody bringing back summer again." Sings Thoreau :-

"His steady sails he never furls At any time $0^{\prime}$ year, And perching now on winter's curls, He whistles in his ear."

But his voice is that of a savage, - strident and disagreeable.

I have often wondered how this bird was kept in check; in the struggle for existence it would appear to have greatly the advantage of other birds. It cannot, for instance, be beset with one tenth of the dangers that threaten the robin, and yet apparently there are a thousand robins to every shrike. It builds a warm, compact nest in the mountains and dense woods, and lays six eggs, which would indicate a rapid increase. The pigeon lays but two eggs, and is preyed upon by both man and beast, millions of them meeting a murderous death every year; yet always some part of the country is swarming with untold numbers of them. ${ }^{1}$ But the shrike is one of our rarest birds. I myself seldom see more than two each year, and before I became an observer of birds I never saw any.

In size the shrike is a little inferior to the blue jay, with much the same form. If you see an unknown bird about your orchard or fields in November or December of a bluish grayish complexion, with dusky wings and tail that show markings of white, flying rather heavily from point to point, or

1 This is no longer the case. The passenger pigeon now seems on the verge of extinction (1895). 
alighting down in the stubble occasionally, it is pretty sure to be the shrike.

Nature never tires of repeating and multiplying the same species. She makes a million bees, a million birds, a million mice or rats, or other animals, so nearly alike that no eye ean tell one from another; but it is rarely that she issues a small and a large edition, as it were, of the same species. Yet she has done it in a few cases among the birds with hardly more difference than a foot-note added or omitted. The cedar-bird, for instance, is the Bohemian waxwing or chatterer in smaller type, copied even to the minute, wax-like appendages that bedeck the ends of the wing-quills. It is about one third smaller, and a little lighter in color, owing perhaps to the fact that it is confined to a warmer latitude, its northward range seeming to end about where that of its larger brother begins. Its flight, its note, its manners, its general character and habits, are almost identical with those of its prototype. It is confined exclusively to this continent, while the chatterer is an Old World bird as well, and ranges the northern parts of both continents. The latter comes to us from the hyperborean regions, brought down oceasionally by the great cold waves that originate in those high latitudes. It is a bird of Siberian and Alaskan evergreens, and passes its life for the most part far beyond the haunts of man. I have never seen the bird, but small bands of them make excur- 
sions every winter down into our territory from British America. Audubon, I believe, saw them in Maine; other observers have seen them in Minnesota. It has the crest of the cedar-bird, the same yellow border to its tail, but is marked with white on its wings, as if a snowflake or two had adhered to it from the northern cedars and pines. If you see about the evergreens in the coldest, snowiest weather what appear to be a number of very large cherrybirds, observe them well, for the chances are that visitants from the circumpolar regions are before your door. It is a sign, also, that the frost legions of the north are out in great force and carrying all before them.

Our cedar or cherry bird is the most silent bird we have. Our neutral-tinted birds, like him, as a rule, are our finest songsters; but he has no song or call, uttering only a fine bead-like note on taking flight. This note is the cedar-berry rendered back in sound. When the ox-heart cherries, which he has only recently become acquainted with, have had time to enlarge his pipe and warm his heart, I shall expect more music from him. But in lieu of music, what a pretty compensation are those minute, almost artificial-like, plumes of orange and vermilion that tip the ends of his wing quills! Nature could not give him these and a song too. She has given the hummingbird a jewel upon his throat, but no song, save the hum of his wings.

Another bird that is occasionally borne to us on the crest of the cold waves from the frozen zone, and 
that is repeated on a smaller scale in a permanent resident, is the pine grosbeak; his alter ego, reduced in size, is the purple finch, which abounds in the higher latitudes of the temperate zone. The color and form of the two birds are again essentially the same. The females and young males of both species are of a grayish brown like the sparrow, while in the old males this tint is imperfectly hidden beneath a coat of carmine, as if the color had been poured upon their heads, where it is strongest, and so oozed down and through the rest of the plumage. Their tails are considerably forked, their beaks cone-shaped and heavy, and their flight undulating. Those who have heard the grosbeak describe its song as similar to that of the finch, though no doubt it is louder and stronger. The finch's instrument is a fife tuned to love and not to war. He blows a clear, round note, rapid and intricate, but full of sweetness and melody. His hardier relative with that larger beak and deeper chest must fill the woods with sounds. Audubon describes its song as exceedingly rich and full.

As in the case of the Bohemian waxwing, this bird is also common to both worlds, being found through Northern Europe and Asia and the northern parts of this continent. It is the pet of the pine-tree and one of its brightest denizens. Its visits to the State's are irregular and somewhat mysterious. A great flight of them occurred in the winter of 1874-7\%. They attracted attention all over the country. Several other flights of them have occurred during the 
century. When this bird comes, it is so unacquainted with man that its tameness is delightful to behold. It thrives remarkably well in captivity, and in a couple of weeks will become so tame that it will hop down and feed out of its master's or mistress's hand. It comes from far beyond the region of the apple, yet it takes at once to this fruit, or rather to the seeds, which it is quick to divine, at its core.

Close akin to these two birds, and standing in the same relation to each other, are two other birds that come to us from the opposite zone, - the torrid, namely, the blue grosbeak and his petit duplicate, the indigo-bird. The latter is a common summer resident with us, - a bird of the groves and bushy fields, where his bright song may be heard all through the long summer day. I hear it in the dry and parched August when most birds are silent, sometimes delivered on the wing and sometimes from the perch. Indeed, with me its song is as much a midsummer sound as is the brassy crescendo of the cicada. The memory of its note calls to mind the flame-like quiver of the heated atmosphere and the bright glare of the meridian sun. Its color is much more intense than that of the common bluebird, as summer skies are deeper than those of April, but its note is less mellow and tender. Its original, the blue grosbeak, is an uncertain wanderer from the south, as the pine grosbeak is from the north. I have never seen it north of the District of Columbia. It has a loud, vivacious song, of which it is not 
stingy, and which is a large and free rendering of the indigo's, and belongs to summer more than to spring. The bird is colored the same as its lesser brother, the males being a deep blue and the females a modest drab. Its nest is usually placed low down, as is the indigo's, and the male carols from the tops of the trees in its vicinity in the same manner. Indeed, the two birds are strikingly alike in every respect except in size and in habitat, and, as in each of the other cases, the lesser bird is, as it were, the point, the continuation, of the larger, carrying its form and voice forward as the reverberation carries the sound.

I know the ornithologists, with their hair-splittings, or rather feather-splittings, point out many differences, but they are unimportant. The fractions may not agree, but the whole numbers are the same. 



\section{VII}

\section{A BED OF BOUGHS}

WHEN Aaron came again to camp and tramp with me, or, as he wrote, "to eat locusts and wild honey with me in the wilderness," it was past the middle of August, and the festival of the season neared its close. We were belated guests, but perhaps all the more eager on that account, especially as the country was suffering from a terrible drought, and the only promise of anything fresh or tonic or cool was in primitive woods and mountain passes.

"Now, my friend," said I, "we can go to Canada, or to the Maine woods, or to the Adirondacks, and thus have a whole loaf and a big loaf of this bread which you know as well as I will have heavy streaks in it, and will not be uniformly sweet; or we can seek nearer woods, and content ourselves with one week instead of four, with the prospect of a keen relish to the last. Four sylvan weeks sound well, but the poetry is mainly confined to the first one. We can take another slice or two of the Catskills, san we not, without being sated with kills and dividing ridges?"

"Anywhere," replied Aaron, "so that we have a good tramp and plenty of primitive woods. No 
doubt we should find good browsing on Peakamoose, and trout enough in the streams at its base."

So without further ado we made ready, and in due time found ourselves, with our packs on our backs, entering upon a pass in the mountains that led to the valley of the Rondout.

The scenery was wild and desolate in the extreme, the mountains on either hand looking as if they had been swept by a tornado of stone. Stone avalanches hung suspended on their sides, or had shot down into the chasm below. It was a kind of Alpine scenery where crushed and broken bowlders covered the earth instead of snow.

In the depressions in the mountains the rocky fragments seemed to have accumulated, and to have formed what might be called stone glaciers that were creeping slowly down.

Two hours' march brought us into heavy timber where the stone cataclysm had not reached, and before long the soft voice of the Rondout was heard in the gulf below us. We paused at a spring run, and I followed it a few yards down its mountain stairway, carpeted with black moss, and had my first glimpse of the unknown stream. I stood upon rocks and looked many feet down into a still, sunlit pool and saw the trout disporting themselves in the transparent water, and I was ready to encamp at once; but my companion, who had not been tempted by the view, insisted upon holding to our original purpose, which was to go farther up the stream. We passed a clearing with three or four houses and a saw-mill. 
The dam of the latter was filled with such clear water that it seemed very shallow, and not ten or twelve feet deep, as it really was. The fish were as conspicuous as if they had been in a pail.

Two miles farther up we suited ourselves and went into camp.

If there ever was a stream cradled in the rocks, detained lovingly by them, held and fondled in a rocky lap or tossed in rocky arms, that stream is the Rondout. Its course for several miles from its head is over the stratified rock, and into this it has worn a channel that presents most striking and peculiar features. Now it comes silently along on the top of the rock, spread out and flowing over that thick, dark green moss that is found only in the coldest streams; then drawn into a narrow canal only four or five feet. wide, through which it shoots, black and rigid, to be presently caught in a deep basin with shelving, overhanging rocks, beneath which the phœbe-bird builds in security, and upon which the fisherman stands and casts his twenty or thirty feet of line without fear of being thwarted by the brush; then into a black, well-like pool, ten or fifteen feet deep, with a smooth, circular wall of rock on one side worn by the water through long ages; or else into a deep, oblong pocket, into which and out of which the water glides without a ripple.

The surface rock is a coarse sandstone superincum. bent upon a lighter-colored conglomerate that looked like Shawangunk grits, and when this latter is reached by the water it seems to be rapidly disinto 
grated by it, thus forming the deep excavations al luded to.

My eyes had never before beheld such beauty in a mountain stream. The water was almost as transparent as the air, - was, indeed, like liquid air; and as it lay in these wells and pits enveloped in shadow, or lit up by a chance ray of the vertical sun, it was a perpetual feast to the eye, - so cool, so deep, so pure; every reach and pool like a vast spring. You lay down and drank or dipped the water up in your cup, and found it just the right degree of refreshing coldness. One is never prepared for the clearness of the water in these streams. It is always a surprise. See them every year for a dozen years, and yet, when you first come upon one, you will utter an exclamation. I saw nothing like it in the Adirondacks, nor in Canada. Absolutely without stain or hint of impurity, it seems to magnify like a lens, so that the bed of the stream and the fish in it appear deceptively near. It is rare to find even a trout stream that is not a little "off color," as they say of liamonds, but the waters in the section of which I am writing have the genuine ray; it is the undimmed snd untarnished diamond.

If I were a trout, I should ascend every stream till I found the Rondout. It is the ideal brook. What homes these fish have, what retreats under the rocks, what paved or flagged courts and areas, what crystal depths where no net or snare can reach them! - no mud, no sediment, but here and there in the clefts and seams of the rock patches of white gravel, — spawning beds ready-made. 
The finishing touch is given by the moss with which the rock is everywhere earpeted. Even in the narrow grooves or channels where the water runs the swiftest, the green lining is unbroken. It sweeps down under the stream and up again on the other side, like some firmly-woven texture. It softens every outline and cushions every stone. At a certain depth in the great basins and wells it of course ceases, and only the smooth-swept flagging of the place-rock is visible.

The trees are kept well back from the margin of the stream by the want of soil, and the large ones unite their branches far above it, thus forming a high winding gallery, along which the fisherman passes and makes his long casts with scarcely an interruption from branch or twig. In a few places he makes no cast, but sees from his rocky perch the water twenty feet below him, and drops his hook into it as into a well.

We made camp at a bend in the creek where there was a large surface of mossy rock uncovered by the shrunken stream, - a clean, free space left for us in the wilderness that was faultless as a kitchen and dining-room, and a marvel of beauty as a loungingroom, or an open court, or what you will. An obsolete wood or bark road conducted us to it, and disappeared up the hill in the woods beyond. A loose bowlder lay in the middle, and on the edge next the stream were three or four large natural wash-basins scooped out of the rock, and ever filled ready for use. Our lair we carved out of the thick brush 
under a large birch on the bank. Here we planted our flag of smoke and feathered our nest with balsam and hemlock boughs and ferns, and laughed at your four walls and pillows of down.

Wherever one encamps in the wonds, there is home, and every object and feature about the place take on a new interest and assume a near and friendly relation to one.

We were at the head of the best fishing. There was an old bark-clearing not far off which afforded us a daily dessert of most delicious blackberries, an important item in the woods, - and then all the features of the place - a sort of cave above ground - were of the right kind.

There was not a mosquito, or gnat, or other pest in the woods, the cool nights having already cut them off. The trout were sufficiently abundant, and afforded us a few hours' sport daily to supply our wants. The only drawback was, that they were out of season, and only palatable to a woodman's keen appetite. What is this about trout spawning in October and November, and in some cases not till March? These trout had all spawned in August, every one of them. The coldness and purity of the water evidently made them that much earlier. The game laws of the State protect the fish after September first, proceeding upon the theory that its spawning season is later than that, - as it is in many cases, but not in all, as we found out.

The fish are small in these streams, seldom weighing over a few ounces. Occasionally a large one is 
seen of a pound or pound and a half weight. I remember one such, as black as night, that ran under a black rock. But I remember much more distinetly a still larger one that I caught and lost one eventful day.

I had him on my hook ten minutes, and actually got my thumb in his mouth, and yet he escaped.

It was only the over-eagerness of the sportsman. I imagined I could hold him by the teeth.

The place where I struck him was a deep wellhole, and I was perched upon a log that spanned it ten or twelve feet above the water. The situation was all the more interesting because I saw no possible way to land my fish. I could not lead him ashore, and my frail tackle could not be trusted to lift him sheer from that pit to my precarious perch. What should I do? call for help? but no help was near. I had a revolver in my pocket and might have shot him through and through, but that novel proceeding did not occur to me until it was too late. I would have taken a Sam Patch leap into the water, and have wrestled with my antagonist in his own element, but I knew the slack, thus sure to occur, would probably free him; so I peered down upon the beautiful creature and enjoyed my triumph as far as it went. He was caught very lightly through his upper jaw, and I expected every struggle and somersault would break the hold. Presently I saw a place in the rocks where I thought it possible, with such an incentive, to get down within reach of the water: by careful manœuvring I slipped my polo 
behind me and got hold of the line, which I cut and wound around my finger; then I made my way toward the end of the log and the place in the rocks, leading my fish along much exhausted on the top of the water. By an effort worthy the occasion I got down within reach of the fish, and, as I have already confessed, thrust my thumb into his mouth and pinched his cheek; he made a spring and was free from my hand and the hook at the same time; for a moment he lay panting on the top of the water, then, recovering himself slowly, made his way down through the clear, cruel element beyond all hope of recapture. My blind impulse to follow and try to seize him was very strong, but I kept my hold and peered and peered long after the fish was lost to view, then looked my mortification in the face and laughed a bitter laugh.

"But, hang it! I had all the fun of catching the fish, and only miss the pleasure of eating him, which at this time would not be great."

"The fun, I take it," said my soldier, "is in tri.amphing, and not in being beaten at the last."

"Well, have it so; but I would not exchange those ten or fifteen minutes with that trout for the tame two hours you have spent in catching that string of thirty. To see a big fish after days of small fry is an event; to have a jump from one is a glimpse of the sportsman's paradise; and to hook one, and actually have him under your control for ten minutes, - why, that is the paradise itself $\mathrm{nm}$ long as it lasts." 
One day I went down to the house of a settler a mile below, and engaged the good dame to mako us a couple of loaves of bread, and in the evening wo went down after them. How elastic and exhilarating the walk was through the cool, transparent shadows! The sun was gilding the mountains, and its yellow light seemed to be reflected through all the woods. At one point we looked through and along a valley of deep shadow upon a broad sweep of mountain quite near and densely clothed with woods, flooded from base to summit by the setting sun. It was a wild, memorable scene. What power and effectiveness in Nature, I thought, and how rarely an artist catches her touch! Looking down upon or squarely into a mountain covered with a heary growth of birch and maple, and shone upon by tho sun, is a sight peculiarly agreeable to me. How closely the swelling umbrageous heads of the trent fit together, and how the eye revels in the flowin; and easy uniformity, while the mind feels the rug. gedness and terrible power beneath!

As we came back the light yet lingered on the top of Slide Mountain.

"The last that parleys with the setting sun,"

said I, quoting Wordsworth.

"That line is almost Shakespearean," said my companion. "It suggests that great hand at least, though it has not the grit and virility of the more primitive bard. What triumph and fresh morning power in Shakespeare's lines that will occur to us at sunrise to-morrow! - 
" 'And jocund day

Stands tiptoe on the misty mountain tops.'

Or in this: -

" Full many a glorious morning have I seen
Flatter the mountain tops with sovran eye."

There is savage, perennial beauty there, the quality that Wordsworth and nearly all the modern poets lack."

"But Wordsworth is the poet of the mountains," said I, "and of lonely peaks. True, he does not express the power and aboriginal grace there is in them, nor toy with them and pluck them up by the hair of their heads, as Shakespeare does. There is something in Peakamoose yonder, as we see it from this point, cutting the blue vault with its dark, serrated edge, not in the bard of Grasmere; but he expresses the feeling of loneliness and insignificance that the cultivated man has in the presence of mountains, and the burden of solemn emotion they give rise to. Then there is something much more wild and merciless, much more remote from human interests and ends, in our long, high, wooded ranges than is expressed by the peaks and scarred groups of the lake country of Britain. These mountains we behold and cross are not picturesque, - they are wild and inhuman as the sea. In them you are in a maze, in a weltering world of woods; you can see neither the earth nor the sky, but a confusion of the growth and decay of centuries, and must traverse them by your compass or your science of woodcraft, - a rift through the trees giving one a glimpse of 
the opposite range or of the valley beneath, and he is more at sea than ever; one does not know his own farm or settlement when framed in these mountain treetops; all look alike unfamiliar."

Not the least of the charm of camping out is your camp-fire at night. What an artist! What pictures are boldly thrown or faintly outlined upon the canvas of the night! Every object, every attitude of your companion, is striking and memorable. You see effects and groups every moment that you would give money to be able to carry away with you in enduring form. How the shadows leap, and skulk, and hover about! Light and darkness are in perpetual tilt and warfare, with first the one unhorsed, then the other. The friendly and cheering fire, what acquaintance we make with it! We had almost forgotten there was such an element, we had so long known only its dark offspring, heat. Now we see the wild beauty uncaged and note its manner and temper. How surely it creates its own draft and sets the currents going, as force and enthusiasm always will! It carves itself a chimney out of the fluid and houseless air. A friend, a ministering angel, in subjection; a fiend, a fury, a monster, ready to devour the world, if ungoverned. By day it burrows in the ashes and sleeps; at night it comes forth and sits upon its throne of rude logs, and rules the camp, a sovereign queen.

Near camp stood a tall, ragged yellow birch, its partially cast-off bark hanging in crisp sheets or dense rolls. 
"That tree needs the barber," we said, "and shall have a call from him to-night."

So after dark I touched a match into it, and wo saw the flames creep up and wax in fury until the whole tree and its main branches stood wrapped in a sheet of roaring flame. It was a wild and striking spectacle, and must have advertised our camp to every nocturnal creature in the forest.

What does the camper think about when lounging around the fire at night? Not much, - of the sport of the day, of the big fish he lost and might have saved, of the distant settlement, of to-morrow's plans. An owl hoots off in the mountain and he thinks of him; if a wolf were to howl or a panther to scream, he would think of him the rest of the night. As it is, things flicker and hover through his mind, and he hardly knows whether it is the past or the present that possesses him. Certain it is, he feels the hush and solitude of the great forest, and, whether he will or not, all his musings are in some way cast upon that huge background of the night. Unless he is an old camper-out, there will be an undercurrent of dread or half fear. My companion said he could not help but feel all the time that there ought to be a sentinel out there pacing up and down. One seems to require less sleep in the woods, as if the ground and the untempered air rested and refreshed him sooner. The balsam and the hemlock heal his aches very quickly. If one is awakened often during the night, as he invariably is, he does not feel that sediment of sleep in his 
mind next day that he does when the same interruption occurs at home; the boughs have drawn it all out of him.

And it is wonderful how rarely any of the housed and tender white man's colds or influenzas come through these open doors and windows of the woods. It is our partial isolation from Nature that is dangerous; throw yourself unreservedly upon her and she rarely betrays you.

If one takes anything to the woods to read, he seldom reads it; it does not taste good with such primitive air.

There are very few camp poems that I know of, poems that would be at home with one on such an expedition; there is plenty that is weird and spectral, as in Poe, but little that is woody and wild as this scene is. I recall a Canadian poem by the late C. D. Shanly - the only one, I believe, the author ever wrote - that fits well the distended pupil of the mind's eye about the camp-fire at night. It was printed many years ago in the "Atlantic Monthly," and is called "The Walker of the Snow;" it begins thus:-

" 'Speed on, speed on, good master;

The camp lies far away;

We must cross the haunted valley

Before the close of day." "'

"That has a Canadian sound," said Aaron; "give os more of it."

" How the snow-blight came upon me

I will tell you as we go, -

The blight of the shadow hunter

Who walks the midnight snow.' 
And so on. The intent seems to be to personify the fearful cold that overtakes and benumbs the traveler in the great Canadian forests in winter. This stanza brings out the silence or desolation of the scene very effectively, - a scene without sound or motion:-

" 'Save the wailing of the moose-bird

With a plaintive note and low;

And the skating of the red leaf

Upon the frozen snow.'

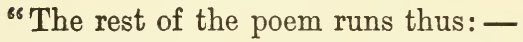

" 'And said I, Though dark is falling, And far the camp must be, Yet my heart it would be lightsome If I had but company.

"And then I sang and shouted, Keeping measure as I sped, To the harp-twang of the snow-shoo As it sprang beneath my tread.

" Nor far into the valley

Had I dipped upon my way, When a dusky figure joined me

In a capuchin of gray,

"'Bending upon the snow-shoes

With a long and limber stride; And I hailed the dusky stranger,

As we traveled side by side.

" 'But no token of communion Gave he by word or look, And the fear-chill fell upon me? At the crossing of the brook.

" 'For I saw by the sickly moonlight,

As I followed, bending low, That the walking of the stranger

Left no foot-marks on the snow. 
" 'Then the fear-chill gathered o'er me,

Like a shroud around me cast,

As I sank upon the snow-drift

Where the shadow hunter passed.

a And the otter-trappers found me,

Before the break of day,

With my dark hair blanched and whitened

As the snow in which I lay.

" But they spoke not as they raised me;

For they knew that in the night

I had seen the shadow hunter

And had withered in his sight.

" 'Sancta Maria speed us!

The sun is fallen low:

Before us lies the valley

Of the Walker of the Snow !",

"Ah!" exclaimed my companion. "Let us pile on more of those dry birch-logs; I feel both the 'fear-chill' and the 'cold-chill' creeping over me. How far is it to the valley of the Neversink?"

"About three or four hours' march, the man said."

"I hope we have no haunted valleys to cross?"

"None," said I, "but we pass an old log cabin about which there hangs a ghostly superstition. At a certain hour in the night, during the time the bark is loose on the hemlock, a female form is said to steal from it and grope its way into the wilderness. The tradition runs that her lover, who was a barkpeeler and wielded the spud, was killed by his rival, who felled a tree upon him while they were at work. The girl, who helped her mother cook for the 'hands,' was crazed by the shock, and that night stole forth into the woods and was never seen or 
heard of more. There are old hunters who aver that her cry may still be heard at night at the head of the valley whenever a tree falls in the stillness of the forest."

"Well, I heard a tree fall not ten minutes ago," said Aaron; "a distant, rushing sound with a subdued crash at the end of it, and the only answering cry I heard was the shrill voice of the screech owl off yonder against the mountain. But maybe it was not an owl," said he after a moment; "let us help the legend along by believing it was the voice of the lost maiden."

"By the way," continued he, "do you remember the pretty creature we saw seven years ago in the shanty on the West Branch, who was really helping her mother cook for the hands, a slip of a girl twelve or thirteen years old, with eyes as beautiful and bewitching as the waters that flowed by her cabin? I was wrapped in admiration till she spoke; then how the spell was broken! Such a voice! It was like the sound of pots and pans when you expected to hear a lute."

The next day we bade farewell to the Rondout, and set out to cross the mountain to the east branch of the Neversink.

"We shall find tame waters compared with these, I fear, - a shriveled stream brawling along over loose stones, with few pools or deep places."

Our course was along the trail of the bark-men who had pursued the doomed hemlock to the last tree at the head of the valley. As we passed along, 
a red steer stepped out of the bushes into the road ahead of us, where the sunshine fell full upon him, and, with a half-scared, beautiful look, beggged alms of salt. We passed the Haunted Shanty; but both it and the legend about it looked very tame at ten o'clock in the morning. After the road had faded out, we took to the bed of the stream to avoid the gauntlet of the underbrush, skipping up the mountain from bowlder to bowlder. Up and up we went, with frequent pauses and copious quaffing of tho cold water. My soldier declared a "haunted valley" would be a godsend; anything but endless dragging of one's self up such an Alpine stairway. The winter wren, common all through the woods, peeped and scolded at us as we sat blowing near the summit, and the oven-bird, not quite sure as to what manner of creatures we were, hopped down a limb to within a few feet of us and had a good look, then darted off into the woods to tell the news. I also noted the Canada warbler, the chestnut-sided warbler, and the black-throated blue-back, - the latter most abundant of all. Up these mountain brooks, too, goes the belted kingfisher, swooping around through the woods when he spies the fisherman, then wheeling into the open space of the stream and literally making a "blue streak" down under the branches.

At last the stream which had been our guide was lost under the rocks, and before long the top was gained. These mountains are horse-shaped. Thero is always a broad, smooth back, more or less de- 
pressed, which the hunter aims to bestride; rising rapidly from this is pretty sure to be a rough, curving ridge that carries the forest up to some highest peak. We were lucky in hitting the saddle, but we could see a little to the south the sharp, steep neck of the steed sweeping up toward the sky with an erect mane of balsam fir.

These mountains are steed-like in other respects: any timid and vacillating course with them is sure to get you into trouble. One must strike out boldly, and not be disturbed by the curveting and shying; the valley you want lies squarely behind them, but farther off than you think, and if you do not go for it resolutely you will get bewildered and the mountain will play you a trick.

I may say that Aaron and I kept a tight rein and a good pace till we struck a watercourse on the other side, and that we clattered down it with no want of decision till it emptied into a larger stream which we knew must be the East Branch. An abandoned fishpole lay on the stones, marking the farthest point reached by some fisherman. According to our reckoning, we were five or six miles above the settlement, with a good depth of primitive woods all about us.

We kept on down the stream, now and then pausing at a likely place to take some trout for dinner, and with an eye out for a good camping-ground. Many of the trout were full of ripe spawn, and a few had spawned, the season with them being a little later than on the stream we had left, perhaps 
because the water was less cold. Neither had the creek here any such eventful and startling career. It led, indeed, quite a humdrum sort of life under the roots and fallen treetops and among the loose stones. At rare intervals it beamed upon us from some still reach or dark cover, and won from us our best attention in return.

The day was quite spent before we had pitched our air-woven tent and prepared our dinner, and we gathered boughs for our bed in the gloaming. Breakfast had to be caught in the morning and was not served early, so that it was nine o'clock before wo were in motion. A little bird, the red-eyed vireo, warbled most cheerily in the trees above our camp, and, as Aaron said, "gave us a good send-off." We kept down the stream, following the inevitable bark road.

My companion had refused to look at another "dividing ridge" that had neither path nor way, and henceforth I must keep to the open road or travel alone. Two hours' tramp brought us to an old clearing with some rude, tumble-down log buildings that many years before had been occupied by the bark and lumber men. The prospect for trout was so good in the stream hereabouts, and the scene so peaceful and inviting, shone upon by the dreamy August sun, that we concluded to tarry here until the next day. It was a page of pioneer history opened to quite unexpectedly. A dim footpath led us a few yards to a superb spring, in which a trout from the near creek had taken up his abode. 
We took possession of what had been a shingle-shop, attracted by its huge fireplace. We floored it with balsam boughs, hung its walls with our "traps," and sent the smoke curling again from its disused chimney.

The most musical and startling sound we heard in the woods greeted our ears that evening about sundown as we sat on a log in front of our quarters, the sound of slow, measured pounding in the valley below us. We did not know how near we were to human habitations, and the report of the lumberman's mallet, like the hammering of a great woodpecker, was music to the ear and news to the mind. The air was still and dense, and the silence such as alone broods over these little openings in the primitive woods. My soldier started as if he had heard a signal-gun. The sound, coming so far through the forest, sweeping over those great wind-harps of trees, became wild and legendary, though probably made by a lumberman driving a wedge or working about his mill.

We expected a friendly visit from porcupines that night, as we saw where they had freshly gnawed all about us; hence, when a red squirrel came and looked in upon us very early in the morning and awoke us by his snickering and giggling, my comrade cried out, "There is your porcupig." How the frisking red rogue seemed to enjoy what he had found! He looked in at the door and snickered, then in at the window, then peeked down from beween the rafters and cachinnated till his sides must 
have ached; then struck an attitude upon the chimney, and fairly squealed with mirth and ridicule. In fact he grew so obstreperous, and so disturbed our repose, that we had to "shoo" him away with one of our boots. He declared most plainly that he had never before seen so preposterous a figure as we cut lying there in the corner of that old shanty.

The morning boded rain, the week to which wo had limited ourselves drew near its close, and wo concluded to finish our holiday worthily by a good square tramp to the railroad station, twenty-three miles distant, as it proved. Two miles brought us to stumpy fields, and to the house of the upper inhabitant. They told us there was a short cut across the mountain, but my soldier shook his head.

"Better twenty miles of Europe," said he, getting Tennyson a little mixed, "than one of Cathay, or Slide Mountain either."

Drops of the much-needed rain began to come down, and I hesitated in front of the woodshed.

"Sprinkling weather always comes to some bad end," said Aaron, with a reminiscence of an old couplet in his mind, and so it proved, for it did not get beyond a sprinkle, and the sun shone out before noon.

In the next woods I picked up from the middle $f$ the road the tail and one hind leg of one of our sative rats, the first $I$ had ever seen except in a museum. An owl or fox had doubtless left it the night before. It was evident the fragments had once formed part of a very elegant and slender crea- 
ture. The fur that remained (for it was not hair) was tipped with red. My reader doubtless knows that the common rat is an importation, and that there is a native American rat, usually found much farther south than the locality of which I am writing, that lives in the woods, - a sylvan rat, very wild and nocturnal in his habits, and seldom seen even by hunters or woodmen. Its eyes are large and fine, and its form slender. It looks like only a far-off undegenerate cousin of the filthy creature that has come to us from the long-peopled Old World. Some creature ran between my feet and the fire toward morning, the last night we slept in the woods, and I have little doubt it was one of these wood-rats.

The people in these back settlements are almost as shy and furtive as the animals. Even the men look a little scared when you stop them by your questions. The children dart behind their parents when you look at them. As we sat on a bridge resting, - for our packs still weighed fifteen or twenty pounds each, - two women passed us with pails on their arms, going for blackberries. They filed by with their eyes down like two abashed nuns.

In due time we found an old road, to which we had been directed, that led over the mountain to the West Branch. It was a hard pull, sweetened by blackberries and a fine prospect. The snowbird was common along the way, and a solitary wild pigeon shot through the woods in front of us, recalling the nests we had seen on the East Branch, - 
little scaffoldings of twigs scattered all through tho trees.

It was nearly noon when we struck the West Branch, and the sun was scalding hot. We knew that two and three pound trout had been taken there, and yet we wet not a line in its waters. 'The scene was primitive, and carried one back to the days of his grandfather, stumpy fields, $\log$ fences, $\log$ houses and barns. A boy twelve or thirteen years old came out of a house ahead of us eating a piece of bread-and-butter. We soon overtook him and held converse with him. He knew the land well, and what there was in the woods and the waters. He had walked out to the railroad station, fourteen miles distant, to see the cars, and back the same day. I asked him about the flies and mosquitoes, etc. $\mathrm{He}$ said they were all gone except tho "blunder-heads;" there were some of them left yet.

"What are blunder-heads?" I inquired, sniffing new game.

"The pesky little fly that gets into your eye when you are a-fishing."

Ah, yes! I knew him well. We had got acquainted some days before, and I thankel the boy for the name. It is an insect that hovers heforo your eye as you thread the streams, and you are forever vaguely brushing at it under the delusion that it is a little spider suspended from your hat-brim; and just as you want to see elearest, into your eye it goes, head and ears, and is caught between the lids. You miss your cast, but you catch a "blunder-head." 
We paused under a bridge at the mouth of Biscuit Brook and ate our lunch, and I can recommend it to be as good a wayside inn as the pedestrian need look for. Better bread-and-milk than we had there I never expect to find. The milk was indeed so good that Aaron went down to the little log house under the hill a mile farther on and asked for more; and being told they had no cow, he lingered five minutes on the door-stone with his sooty pail in his hand, putting idle questions about the way and distance, etc., to the mother while he refreshed himself with the sight of a well-dressed and comely-looking young girl, her daughter.

"I got no milk," said he, hurrying on after me, "but I got something better, only I cannot divide it."

"I know what it is," replied I; "I heard her voice."

"Yes, and it was a good one, too. The sweetest sound I ever heard," he went on, "was a girl's voice after I had been four years in the army, and, by Jove! if I did n't experience something of the same pleasure in hearing this young girl speak after a week in the woods. She had evidently been out in the world and was home on a visit. It was a different look she gave me from that of the natives. This is better than fishing for trout," said he. "You drop in at the next house."

But the next house looked too unpromising.

"There is no milk there," said I, "unless they keep a goat." 
"But could we not," said my facetious companion, "go it on that?"

A couple of miles beyond I stopped at a house that enjoyed the distinction of being clapboarded, and had the good fortune to find both the milk and the young lady. A mother and her daughter wero again the only occupants save a babe in the cradle, which the young woman quickly took occasion to disclaim.

"It has not opened its dear eyes before since its mother left. Come to aunty," and she put out hes hands.

The daughter filled my pail and the mother replenished our stock of bread. They asked me to sit and cool myself, and seemed glad of a stranger to talk with. They had come from an adjoining county five years before, and had carved their little clearing out of the solid woods.

"The men folks," the mother said, "came on ahead and built the house right among the big trees," pointing to the stumps near the door.

One no sooner sets out with his pack upon his back to tramp through the land than all objects and persons by the way have a new and curious interest to him. The tone of his entire being is not a little olevated, and all his perceptions and susceptibilities quickened. I feel that some such statement is necessary to justify the interest that I felt in thia backwoods maiden. A slightly pale face it was, strong and well arched, with a tender, wistful oxpression not easy to forget. 
I had surely seen that face many times before in towns and cities, and in other lands, but I hardly expected to meet it here amid the stumps. What were the agencies that had given it its fine lines and its gracious intelligence amid these simple, primitive scenes? What did my heroine read, or think? or what were her unfulfilled destinies? She wore a sprig of prince's pine in her hair, which gave a touch peculiarly welcome.

"Pretty lonely," she said, in answer to my inquiry; "only an occasional fisherman in summer, and in winter - nobody at all."

And the little new schoolhouse in the woods farther on, with its half dozen scholars and the girlish face of the teacher seen through the open door, nothing less than the exhilaration of a journey on foot could have made it seem the interesting object it was. Two of the little girls had been to the spring after a pail of water, and came struggling out of the woods into the road with it as we passed. They set down their pail and regarded us with a halfcurious, half-alarmed look.

"What is your teacher's name?" asked one of us.

"Miss Lucinde Josephine _— " began the redhaired one, then hesitated, bewildered, when the bright, dark-eyed one cut her short with "Miss Simms," and taking hold of the pail said, "Come on."

"Are there any scholars from above here?" I inquired.

"Yes, Bobbie and Matie," and they hastened toward the door. 
We once more stopped under a bridge for refreshments, and took our time, knowing the train would not go on without us. By four o'clock we wero across the mountain, having passed from the watershed of the Delaware into that of the Hudson. The next eight miles we had a down grade but a rough road, and during the last half of it we had blisters on the bottoms of our feet. It is one of the rewards of the pedestrian that, however tired he may be, he is always more or less refreshed by his journey. His physical tenement has taken an airing. His respiration has been deepened, his circulation quickened. A good draught has carried off the fumes and the vapors. One's quality is intensified; the color strikes in. At noon that day I was much fatigued; at night I was leg-weary and foot-sore, but a fresh, hardy feeling had taken possession of me that lasted for weeks. 



\section{VIII}

\section{BIRDS'-NESTING}

'BIRDS'-NESTING is by no means a failure, even though you find no birds'-nests. You are sure to find other things of interest, plenty of them. A friend of mine says that, in his youth, he used to go hunting with his gun loaded for wild turkeys, and, though he frequently saw plenty of smaller game, he generally came home empty-handed, because he was loaded only for turkeys. But the student of ornithology, who is also a lover of Nature in all her shows and forms, does not go out loaded for turkeys merely, but for everything that moves or grows, and is quite sure, therefore, to bag some game, if not with his gun, then with his eye, or his nose, or his ear. Even a crow's nest is not amiss, or a den in the rocks where the coons or the skunks live, or a log where a partridge drums, or the partridge himself starting up with spread tail, and walking a few yards in advance of you before he goes humming through the woods, or a woodchuck hole, with well beaten and worn entrance, and with the saplings gnawed and soiled about it, or the strong, fetid smell of the fox, which a sharp nose detects here and there, and which is a good perfume in the 
woods. And then it is enough to come upon a spring in the woods and stoop down and drink of the sweet, cold water, and bathe your hands in it, or to walk along a trout brook, which has absorbed the shadows till it has itself become but a denser shade. Then I am always drawn out of my way by a ledge of rocks, and love nothing better than to explore the caverns and dens, or to sit down under the overhanging crags and let the wild scene absorb me.

There is a fascination about ledges! They are an unmistakable feature, and give emphasis and character to the scene. I feel their spell, and must pause awhile. Time, old as the hills and older, looks out of their scarred and weather-worn face. The woods are of to-day, but the ledges, in comparison, are of eternity. One pokes about them as he would about ruins, and with something of the same feeling. They are ruins of the fore world. Here the foundations of the hills were laid; here the earth-giants wrought and builded. They constrain one to silence and meditation; the whispering and rustling trees seem trivial and impertinent.

And then there are birds'-nests about ledges, too, exquisite mossy tenements, with white, pebbly eggs, that I can never gaze upon without emotion. The little brown bird, the phœbe, looks at you from her niche till you are within a few feet of her, when she darts away. Occasionally you may find the nest of some rare wood-warbler forming a little pocket in the apron of moss that hangs down over the damp rocks. 
The sylvan folk seem to know when you are on a peaceful mission, and are less afraid than usual. Did not that marmot to-day guess my errand did not concern him as he saw me approach there from his cover in the bushes? But, when he saw me pause and deliberately seat myself on the stone wall immediately over his hole, his confidence was much shaken. He apparently deliberated awhile, for I heard the leaves rustle as if he were making up his mind, when he suddenly broke cover and came for his hole full tilt. Any other animal would have taken to his heels and fled; but a woodchuck's heels do not amount to much for speed, and he feels his only safety is in his hole. On he came in the most obstinate and determined manner, and I dare say if I had sat down in his hole would have attacked mo unhesitatingly. This I did not give him a chance to do; but, not to be entirely outdone, attempted to set my feet on him in no very gentle manner; but he whipped into his den beneath me with a defiant snort. Farther on, a saucy chipmunk presumed upon my harmless character to an unwonted degree also. I had paused to bathe my hands and face in a little trout brook, and had set a tin cup, which I had partly filled with strawberries as I crossed the field, on a stone at my feet, when along came the chipmunk as confidently as if he knew precisely where he was going, and, perfectly oblivious of my presence, cocked himself up on the rim of the cup and proceeded to eat my choicest berries. I remained motionless and observed him. He had eaten 
but two when the thought seemed to occur to him that he might be doing better, and he began to fill his pockets. Two, four, six, eight of my berries quickly disappeared, and the cheeks of the little vagabond swelled. But all the time he kept eating, that not a moment might be lost. Then he hopped off the cup, and went skipping from stone to stone till the brook was passed, when he disappeared in the woods. In two or three minutes he was back again, and went to stuffing himself as before; then he disappeared a second time, and I imagined told a friend of his, for in a moment or two along came a bobtailed chipmunk, as if in search of something, and passed up, and down, and around, but did not quite hit the spot. Shortly, the first returned a third time, and had now grown a little fastidious, for he began to sort over my berries, and to bite into them, as if to taste their quality. He was not long in loading up, however, and in making off again. But I had now got tired of the joke, and my berries were appreciably diminishing, so I moved away.

- What was most curious about the proceeding was, that the little poacher took different directions each time, and returned from different ways. Was this to elude pursuit, or was he distributing the fruit to his friends and neighbors about, astonishing them with strawberries for lunch?

But I am making slow headway toward finding the birds'-nests, for I had set out on this occasion in hopes of finding a rare nest, - the nest of the black-throated blue-backed warbler, which, it seemed, 
with one or two others, was still wanting to make the history of our warblers complete. The woods were extensive, and full of deep, dark tangles, and looking for any particular nest seemed about as hopeless a task as searching for a needle in a haystack, as the old saying is. Where to begin, and how? But the principle is the same as in looking for a hen's nest, - first find your bird, then watch its movements.

The bird is in these woods, for I have seen him scores of times, but whether he builds high or low, on the ground or in the trees, is all unknown to me. That is his song now, - "twe-twea-twe-e-e-a," with a peculiar summer languor and plaintiveness, and issuing from the lower branches and growths. Presently we - for I have been joined by a companion - discover the bird, a male, insecting in the top of a newly-fallen hemlock. The black, white, and blue of his uniform are seen at a glanee. His movements are quite slow compared with some of the warblers. If he will only betray the locality of that little domicile where his plainly-clad mate is evidently sitting, it is all we will ask of him. But this he seems in no wise disposed to do. Here and there, and up and down, we follow him, often losing him, and as often refinding him by his song; but the clew to his nest, how shall we get it? Does he never go home to see how things are getting on, or to see if his presence is not needed, or to take madam a morsel of food? No doubt he keeps within ear-shot, and a ery of distress or alarm from the mother bird would 
bring him to the spot in an instant. Would that some evil fate would make her cry, then! Presently he encounters a rival. His feeding-ground infringes upon that of another, and the two birds regard each other threateningly. This is a good sign, for thei' nests are evidently near.

Their battle-cry is a low, peculiar chirp, not very fierce, but bantering and confident. They quickly come to blows, but it is a very fantastic battle, and, as it would seem, indulged in more to satisfy their sense of honor than to hurt each other, for neither party gets the better of the other, and they separate a few paces and sing, and squeak, and challenge each other in a very happy frame of mind. The gauntlet is no sooner thrown down than it is again taken up by one or the other, and in the course of fifteen or twenty minutes they have three or four encounters, separating a little, then provoked to return again like two cocks, till finally they withdraw beyond hearing of each other, - both, no doubt, claiming the victory. But the secret of the nest is still kept. Once I think I have it. I catch a glimpse of a bird which looks like the female, and near by, in a small hemlock about eight feet from the ground, my eye detects a nest. But as I come up under it, I can see daylight through it, and that it is empty, - evidently only part finished, not lined or padded yet. Now if the bird will only return and claim it, the point will be gained. But we wait and watch is vain. The architect has knocked off to-day, and we must come again, or continue our search. 
While loitering about here we were much amused by three chipmunks, who seemed to be engaged in some kind of game. It looked very much as if they were playing tag. Round and round they would go, first one taking the lead, then another, all goodnatured and gleeful as schoolboys. There is one thing about a chipmunk that is peculiar: he is never more than one jump from home. Nake a dive at him anywhere and in he goes. He knows whero the hole is, even when it is covered up with leaves. There is no doubt, also, that he has his own senso of humor and fun, as what squirrel has not? I have watched two red squirrels for a half hour coursing through the large trees by the roadside where branches interlocked, and engaged in a game of tag as obviously as two boys. As soon as the pursuer had come up with the pursued, and actually touched him, the palm was his, and away he would go, taxing his wits and his speed to the utmost to elude his fellow.

Despairing of finding either of the nests of the nwo males, we pushed on through the woods to try our luck elsewhere. Before long, just as we were about to plunge down a hill into a dense, swampy part of the woods, we discovered a pair of the birds we were in quest of. They had food in their beaks, and, as we paused, showed great signs of alarm, indicating that the nest was in the immediate vicinity. This was enough. We would pause here and find this nest, anyhow. To make a sure thing of it, wo determined to watch the parent birds till we had 
wrung from them their secret. So we doggedly crouched down and watched them, and they watched us. It was diamond cut diamond. But as we felt sonstrained in our movements, desiring, if possible, to keep so quiet that the birds would, after a while, see in us only two harmless stumps or prostrate logs, we had much the worst of it. The mosquitoes were quite taken with our quiet, and knew us from logs and stumps in a moment. Neither were the birds deceived, not even when we tried the Indian's tactics, and plumed ourselves with green branches. $\mathrm{Ah}$, the suspicious creatures, how they watched us with the food in their beaks, abstaining for one whole hour from ministering that precious charge which otherwise would have been visited every moment! Quite near us they would come at times, between us and the nest, eying us so sharply. Then they would move off, and apparently try to forget our presence. Was it to deceive us, or to persuade himself and mate that there was no serious cause for alarm, that the male would now and then strike up in full song and move off to some distance through the trees? But the mother bird did not allow herself to lose sight of us at all, and both birds, after carrying the food in their beaks a long time, would swallow it themselves. Then they would obtain another morsel and apparently approach very near the nest, when their caution or prudence would come to their aid, and they would swallow the food and hasten away. I thought the young birds would cry out, but not a syllable from them. 
Yet this was, no doubt, what kept the parent birds away from the nest. The clamor the young would have set up on the approach of the old with food would have exposed everything.

After a time I felt sure I knew within a few feet where the nest was concealed. Indeed, I thought I knew the identical bush. Then the birds approached each other again and grew very confidential about another locality some rods below. This puzzled us, and, seeing the whole afternoon might be spent in this manner, and the mystery unsolved, we determined to change our tactics and institute a thorough search of the locality. This procedure soon brought things to a crisis, for, as my companion clambered over a log by a little hemlock, a few yards from where we had been sitting, with a cry of alarm out sprang the young birds from their nest in the hemlock, and, scampering and fluttering over the leaves, disappeared in different directions. This brought the parent birds on the scene in an agony of alarm. Their distress was pitiful. They threw themselves on the ground at our very feet, and fluttered, and cried, and trailed themselves before us, to draw us away from the place, or distract our attention from the helpless young. I shall not forget the male bird, how bright he looked, how sharp the contrast as he trailed his painted plumage there on the dry leaves. Apparently he was scriously disabled. He would start up as if exerting every muscle to fly away, but no use; down he would come, with a helpless, fluttering motion, before he had 
gone two yards, and apparently you had only to go and pick him up. But before you could pick him up, he had recovered somewhat and flown a little farther; and thus, if you were tempted to follow him, you would soon find yourself some distance from the scene of the nest, and both old and young well out of your reach. The female bird was not less solicitous, and practiced the same arts upon us to decoy us away, but her dull plumage rendered her less noticeable. The male was clad in holiday attire, but his mate in an every-day working-garb.

The nest was built in the fork of a little hemlock, about fifteen inches from the ground, and was a thick, firm structure, composed of the finer material of the woods, with a lining of very delicate roots or rootlets. There were four young birds and one addled egg. We found it in a locality about the head-waters of the eastern branch of the Delaware, where several other of the rarer species of warblers, such as the mourning ground, the Blackburnian, the chestnut-sided, and the speckled Canada, spend the summer and rear their young.

Defunct birds'-nests are easy to find; when the leaves fall, then they are in every bush and tree; and one wonders how he missed them; but a live nest, how it eludes one! I have read of a noted criminal who could hide himself pretty effectually in any room that contained the usual furniture; $h$ would embrace the support of a table so as to seen. part of it. The bird has studied the same art: it always blends its nest with the surroundings, and 
8ometimes its very openness hides it; the light itself seems to conceal it. Then the birds build anew ench year, and so always avail themselves of the present and latest combination of leaves and screens, of light and shade. What was very well concealed one season, may be quite exposed the next.

Going a-fishing or a-berrying is a good introduction to the haunts of the birds, and to their nestingplaces. You put forth your hand for the berries, and there is a nest; or your tread by the creeks starts the sandpiper or the water-thrush from the ground where its eggs are concealed, or some shy wood-warbler from a bush. One day, fishing down a deep wooded gorge, my hook eaught on a limb overhead, and on pulling it down I found I had missed my trout, but had caught a hummingbird's nest. It was saddled on the limb as nicely as if it had been a grown part of it.

Other collectors beside the oölogists are looking 'for birds'-nests, - the squirrels and owls and jays and crows. The worst depredator in this direction I know of is the fish crow, and I warn him to keep off my premises, and charge every gumner to spare him not. $\mathrm{He}$ is a small sneak-thief, and will rob the nest of every robin, wood thrush, and oriole ho can come at. I believe he fishes only when he is unable to find birds' eggs or young birds. The genuine crow, the crow with the honest "caw," "caw, I have never caught in such small business, thoug the kingbird makes no discrimination between them, but accuses both alike. 



\section{IX}

\section{THE HALCYON IN CANADA}

THE halcyon or kingfisher is a good guide when 1 you go to the woods. He will not insuro smooth water or fair weather, but he knows every stream and lake like a book, and will take you to the wildest and most unfrequented places. Follow his rattle and you shall see the source of every trout and salmon stream on the continent. You shall seo the Lake of the Woods, and far-off Athabaska and Abbitibbe, and the unknown streams that flow into Hudson's Bay, and many others. His time is tho time of the trout, too, namely, from April to September. He makes his subterranean nest in tho bank of some favorite stream, and then goes on long excursions up and down and over woods and mountains to all the waters within reach, always fishing alone, the true angler that he is, his fellow keeping far ahead or behind, or taking the other branch. He loves the sound of a waterfall, and will sit a long time on a dry limb overhanging the pool below it, and, forgetting his occupation, brood upon his own memories and fancies.

The past season my friend and I took a hint from him, and, when the dog-star began to blaze, set out 
for Canada, making a big detour to touch at salt water and to take New York and Boston on our way.

The latter city was new to me, and we paused there and angled a couple of days and caught an sditor, a philosopher, and a poet, and might have caught more if we had had a mind to, for these waters are full of 'em, and big ones, too.

Coming from the mountainous regions of the Hudson, we saw little in the way of scenery that arrested our attention until we beheld the St. Lawrence, though one gets glimpses now and then, as he is whirled along through New Hampshire and Vermont, that make him wish for a fuller view. It is always a pleasure to bring to pass the geography of one's boyhood; 't is like the fulfilling of a dream; hence it was with partial eyes that I looked upon the Merrimac, the Connecticut, and the Passumpsic, -dusky, squaw-colored streams, whose names I had learned so long ago. The traveler opens his eyes a little wider when he reaches Lake Memphremagog, especially if he have the luck to see it under such a sunset as we did, its burnished surface glowing like molten gold. This lake is an immense trough that accommodates both sides of the fence, though the larger and longer part of it by far is in Canada. Its western shore is bold and picturesque, being skirted by a detachment of the Green Mountains, the main range of which is seen careering along the horizon far to the southwest; to the east and north, whither the railroad takes you, the country is flat and monotonous. 
The first peculiarity one notices about the farms in this northern country is the close proximity of the house and barn, in most eases the two buillings touching at some point, - an arrangement doubtless prompted by the deep snows and severe cold of this latitude. The typical Canadian dwellinghouse is also presently met with on entering the Dominion, - a low, modest structure of hewn spruce logs, with a steep roof (containing two or more dormer windows) that ends in a smart curve, a hint taken from the Chinese pagoda. Even in the more costly brick or stone houses in the towns and vicinity this style is adhered to. It is so universal that one wonders if the reason of it also be not in the climate, the outward curve of the roof shooting the sliding snow farther away from the dwelling. It affords a wide projection, in many cases covering a veranda, and in all cases protecting the doors and windows without interfering with the light. In the better class of clapboarded houses the finish beneath the projecting eaves is also a sweeping curve, opposing and bracing that of the roof. A two-story country house, or a Mansard roof, I do not remember to have seen in Canada; but in places they have become so enamored of the white of the snow that they even whitewash the roofs of their buildings, giving a cluster of them the impression, at a distance, of an encampment of great tents.

As we neared Point Levi, opposite Quehec, we got our first view of the St. Lawrence. "Iliad of rivers!" exclaimed my friend. "Yet unsung!" 
The Hudson must take a back seat now, and a good way back. One of the two or three great watercourses of the globe is before you. No other river, I imagine, carries such a volume of pure cold water to the sea. Nearly all its feeders are trout and salmon streams, and what an airing and what a bleaching it gets on its course! Its history, its antecedents, are unparalleled. The great lakes are its camping grounds; here its hosts repose under the sun and stars in areas like that of states and kingdoms, and it is its waters that shake the earth at Niagara. Where it receives the Saguenay it is twenty miles wide, and when it debouches into the Gulf it is a hundred. Indeed, it is a chain of Homeric sublimities from beginning to end. The great cataract is a fit sequel to the great lakes; the spirit that is born in vast and tempestuous Superior takes its full glut of power in that fearful chasm. If paradise is hinted in the Thousand Islands, hell is unveiled in that pit of terrors.

Its last escapade is the great rapids above Montreal, down which the steamer shoots with its breathless passengers, after which, inhaling and exhaling its mighty tides, it flows calmly to the sea.

The St. Lawrence is the type of nearly all the Canadian rivers, which are strung with lakes and rapids and cataracts, and are full of peril and ad. venture.

Here we reach the oldest part of the continent, geologists tell us; and here we encounter a fragment of the Old World civilization. Quebec presents the 
anomaly of a mediæval European city in the midst of the American landseape. This air, this sky, theso clouds, these trees, the look of these fields, aro what we have always known; but these houses, and streets, and vehicles, and language, and physiognomy aro strange. As I walked upon the grand terrace I saw the robin and kingbird and song sparrow, and thero in the tree, by the Wolfe Monument, our summer warbler was at home. I presently saw, also, that our republican crow was a British subject, and that he behaved here more like his European brother than he does in the States, being less wild and suspicious. On the Plains of Abraham excellent timothy grass was growing and cattle were grazing. We found a path through the meadow, and, with the exception of a very abundant weed with a blue flower, saw nothing new or strange, - nothing but the steep tin roofs of the city and its frowning wall and citadel. Sweeping around the far southern horizon, we could catch glimpses of mountains that were evidently in Maine or New Hampshire; while twelve or fifteen miles to the north the Laurentian ranges, dark and formidable, arrested the eye. Quebec, or the walled part of it, is situated on a point of land shaped not unlike the human foot, looking northeast, the higher and bolder side being next the river, with the main part of the town on the northern slope toward the St. Charles. Its toes are well down in the mud where this stream joins the St. Lawrenee, while the citadel is high on the instep and commands the wholo field. The grand Battery is a little below, on $t \mathbf{r}$ 
brink of the instep, so to speak, and the promenader looks down several hundred feet into the tops of the chimneys of this part of the lower town, and upcn the great river sweeping by northeastward like another Amazon. The heel of our misshapen foot extends indefinitely toward Montreal. Upon it, on a level with the citadel, are the Plains of Abraham. It was up its high, almost perpendicular, sides that Wolfe clambered with his army, and stood in the rear of his enemy one pleasant September morning over a hundred years ago.

To the north and northeast of Quebec, and in full view from the upper parts of the city, lies a rich belt of agricultural country, sloping gently toward the river, and running parallel with it for many miles, called the Beauport slopes. The division of the land into uniform parallelograms, as in France, was a marked feature, and is so throughout the Dominion. A road ran through the midst of it lined with trees, and leading to the falls of the Montmorenci. I imagine that this section is the garden of Quebec. Beyond it rose the mountains. Our eyes looked wistfully toward them, for we had decided to penetrate the Canadian woods in that direction.

One hundred and twenty-five miles from Quebec as the loon flies, almost due north over unbroken spruce forests, lies Lake St. John, the cradle of the terrible Saguenay. On the map it looks like a great cuttlefish with its numerous arms and tentacula reaching out in all directions into the wilds. It is a large oval body of water thirty miles in its greatest dian- 
eter. The season here, owing to a sharp northern sweep of the isothermal lines, is two or three weeks earlier than at Quebee. The soil is warm and fertile, and there is a thrifty growing settlement here with valuable agricultural produce, but no market nearer than Quebec, two hundred and fifty miles distant by water, with a hard, tedious land journey besides. In winter the settlement can have littlo or no communication with the outside world.

To relieve this isolated colony and encourage further development of the St. John region, the Canadian government is building ${ }^{1}$ a wagon-road through the wilderness from Quebee directly to the lake, thus economizing half the distance, as the road when completed will form with the old route, the Saguenay and St. Lawrence, one side of an equilateral triangle. A railroad was projected a few years ago over nearly the same ground, and the contract to build it given to an enterprising Yankee, who pocketed a part of the money and has never been heard of since. The road runs for one hundred miles through an unbroken wilderness, and opens up scores of streams and lakes abounding with trout, into which, until the road-makers fished them, no white man had ever cast a hook.

It was a good prospect, and we resolved to commit ourselves to the St. John road. The services of a young fellow whom, by reason of his impracticable French name, we called Joe, was secured, and after a delay of twenty-four hours we were packed

1 Written in 1877. 
upon a Canadian buckboard with hard-tack in one bag and oats in another, and the journey began. It was Sunday, and we held up our heads more confidently when we got beyond the throng of welldressed church-goers. For ten miles we had a good stone road and rattled along it at a lively pace. In about half that distance we came to a large brick church, where we began to see the rural population or habitans. They came mostly in two-wheeled vehicles, some of the carts quite fancy, in which the young fellows rode complacently beside their girls. The two-wheeler predominates in Canada, and is of all styles and sizes. After we left the stone road, we began to encounter the hills that are preliminary to the mountains. The farms looked like the wilder and poorer parts of Maine or New Hampshire. While Joe was getting a supply of hay of a farmer to take into the woods for his horse, I walked through a field in quest of wild strawberries. The season for them was past, it being the 20 th of July, and I found barely enough to make me think that the strawberry here is far less pungent and high-flavored than with us.

The cattle in the fields and by the roadside looked very small and delicate, the effect, no doubt, of the severe climate. We saw many rude implements of agriculture, such as wooden plows shod with iron.

We passed several parties of men, women, and children from Quebec picnicking in the "bush." Here it was little more than a "bush;" but while in Canada we never heard the woods designated by 
any other term. I noticed, also, that when a distance of a few miles or of a fraction of a mile is to be designated, the French Canadian does not use the term "miles," but says it's so many acres through. or to the next place.

This fondness for the "bush" at this season seems quite a marked feature in the social life of the average Quebecker, and is one of the original Frenoh traits that holds its own among them. Parties leave the city in carts and wagons by midnight, or earlier, and drive out as far as they can the remainder of the night, in order to pass the whole Sunday in the woods, despite the mosquitoes and black flies. Those we saw seemed a decent, harmless set, whose idea of a good time was to be in the open air, and as far into the "bush" as possible.

The post-road, as the new St. John's road is also called, begins twenty miles from Quebec at Stoneham, the farthest settlement. Five miles into the forest upon the new road is the hamlet of La Chance (pronounced La Shaunce), the last house till you reach the lake, one hundred and twenty miles distant. Our destination the firs: night was La Chance's; this would enable us to reach the Jacques Cartier River, forty miles farther, where we proposed to encamp, in the afternoon of the next day.

We were now fairly among the mountains, and the sun was well down behind the trees when we entered upon the post-road. It proved to be a wille, well-built highway, grass-grown, but in good condition. After an hour's travel we began to see sign 
of a clearing, and about six o'clock drew up in front of the long, low, log habitation of La Chance. Their hearthstone was outdoor at this season, and its smoke rose through the still atmosphere in a frail column toward the sky. The family was gathered here and welcomed us cordially as we drew up, the master shaking us by the hand as if we were old friends. His English was very poor, and our French was poorer, but, with Joe as a bridge between us, communication on a pinch was kept up. His wife could speak no English; but her true French politeness and graciousness was a language we could readily understand. Our supper was got ready from our own supplies, while we sat or stood in the open air about the fire. The clearing comprised fifty or sixty acres of rough land in the bottom of a narrow valley, and bore indifferent crops of oats, barley, potatoes, and timothy grass. The latter was just in bloom, being a month or more later than with us. The primitive woods, mostly of birch with a sprinkling of spruce, put a high cavernous wall about the scene. How sweetly the birds sang, their notes seeming to have unusual strength and volume in this forest-bound opening! The principal singer was the white-throated sparrow, which we heard and saw everywhere on the route. $\mathrm{He}$ is called here $l a$ siffleur (the whistler), and very delightful his whistle was. From the forest came the evening hymn of a thrush, the olive-backed perhaps, like, but less clear and full than, the veery's.

In the evening we sat about the fire in rude home- 
made chairs, and had such broken and disjointed talk as we could manage. Our host had lived in Quebec and been a school-teacher there; he had wielded the birch until he lost his health, when he came here and the birehes gave it back to him. He was now hearty and well, and had a family of six or seven children about him.

We were given a good bed that night, and fared better than we expected. About one o'clock I was awakened by suppressed voices outside the window. Who could it be? Had a band of brigands surrounded the house? As our outfit and supplies had not been removed from the wagon in front of the door I got up, and, lifting one corner of the window paper, peeped out: I saw in the dim moonlight four or five men standing about engaged in low conversation. Presently one of the men advanced to the door and began to rap and eall the name of our host. Then I knew their errand was not hostile; but tho weird effect of that regular alternate rapping and calling ran through my dream all the rest of the night. Rat-tat, tat, tat, - La Chance; rat-tat, tat, - La Chanee, five or six times repeated before La Chance heard and responded. Then the door opened and they came in, when it was jabber, jabber, jabber in the next room till I fell asleep.

In the morning, to my inquiry as to who the travelers were and what they wanted, I $\Omega$ Chance said they were old acquaintances going a-fishing, and had stopped to have a little talk.

Breakfast was served early, and we were upon the 
road before the sun. Then began a forty-mile ride through a dense Canadian spruce forest over the drift and bowlders of the paleozoic age. Up to this point the scenery had been quite familiar, - not much unlike that of the Catskills, - but now there was a change; the birches disappeared, except now and then a slender white or paper birch, and spruce everywhere prevailed. A narrow belt on each side of the road had been blasted by fire, and the dry, white stems of the trees stood stark and stiff. The road ran pretty straight, skirting the mountains and threading the valleys, and hour after hour the dark, silent woods wheeled past us. Swarms of black flies - those insect wolves - waylaid us and hung to us till a smart spurt of the horse, where the road favored, left them behind. But a species of large horse-fly, black and vicious, it was not so easy to get rid of. When they alighted upon the horse we would demolish them with the whip or with our felt hats, a proceeding the horse soon came to understand and appreciate. The white and gray Laurentian bowlders lay along the roadside. The soil seemed as if made up of decayed and pulverized rock, and doubtless contained very little vegetable matter. It is so barren that it will never repay clearing and cultivating.

Our course was an up-grade toward the highlands that separate the watershed of St. John Lake from that of the St. Lawrence, and as we proceeded the spruce became smaller and smaller till the trees were seldom more than eight or ten inches in diameter. 
Nearly all of them terminated in a dense tuft at the top, beneath which the stem would be bare for several feet, giving them the appearance, my friend said, as they stood sharply defined along the crests of the mountains, of cannon swabs. Endless, interminable successions of these cannon swabs, each just like its fellow, came and went, came and went, all day. Sometimes we could see the road a mile or two ahead, and it was as lonely and solitary as a path in the desert. Periods of talk and song and jollity were succeeded by long stretches of silence. A buckboard upon such a road does not conduce to a continuous flow of animal spirits. A good brace for the foot and a good hold for the hand is one's main lookout much of the time. We walked up the steeper hills, one of them nearly a mile long, then clung grimly to the board during the rapid descent of the other side.

We occasionally saw a solitary pigeon - in every instance a cock - leading a forlorn life in the wood, a hermit of his kind, or more probably a rejected and superfluous male. We came upon two or three broods of spruce grouse in the road, so tame that one could have knocked them over with poles. We passed many beautiful lakes; among others, the Two Sisters, one on each side of the road. At noon we paused at a lake in a deep valley, and fed the horse and had lunch. I was not long in getting ready my fishing tackle, and, upon a raft made of two logs pinned together, floated out upon the lake and quickly took all the trout we wanted. 
Early in the afternoon we entered upon what is called La Grande Brûlure, or Great Burning, and to the desolation of living woods succeeded the greater desolation of a blighted forest. All the mountains and valleys, as far as the eye could see, had been swept by the fire, and the bleached and ghostly skeletons of the trees alone met the gaze. The fire had come over from the Saguenay, a hundred or more miles to the east, seven or eight years before, and had consumed or blasted everything in its way. We saw the skull of a moose said to have perished in the fire. For three hours we rode through this valley and shadow of death. In the midst of it, where the trees had nearly all disappeared, and where the ground was covered with coarse wild grass, we came upon the Morancy River, a placid yellow stream twenty or twenty-five yards wide, abounding with trout. We walked a short distance along its banks and peered curiously into its waters. The mountains on either hand had been burned by the fire until in places their great granite bones were bare and white.

At another point we were within ear-shot, for a mile or more, of a brawling stream in the valley below us, and now and then caught a glimpse of foaming rapids or cascades through the dense spruce, a trout stream that probably no man had ever fished, as it would be quite impossible to do so in such a maze and tangle of woods.

We neither met, nor passed, nor saw any travelers till late in the afternoon, when we descried far ahead 
a man on horseback. It was a welcome relief. It was like a sail at sea. When he saw us he drew rein and awaited our approach. He, too, had probably tired of the solitude and desolation of the road. He proved to be a young Canadian going to join the gang of workmen at the farther end of the road.

About four o'clock we passed another small lake, and in a few moments more drew up at the bridge over the Jacques Cartier River, and our forty-mile ride was finished. There was a stable here that had been used by the road-builders, and was now used by the teams that hauled in their supplies. This would do for the horse; a snug log shanty built by an old trapper and hunter for use in the winter, a hundred yards below the bridge, amid the spruces on the bank of the river, when rebedded and refurnished, would do for us. The river at this point was a swift, black stream from thirty to forty feet wide, with a strength and a bound like a moose. It was not shrunken and emaciated, like similar streams in a cleared country, but full, copious, and strong. Indeed, one can hardly realize how the lesser watercourses have suffered by the denuding of the land of its forest covering, until he goes into the primitive woods and sees how bounding and athletic they are there. They are literally well fecd and their measure of life is full. In fact, a trout brook is as much a thing of the woods as a moose or deer, and will not thrive well in the open country.

Three miles above our camp was Great Lake Jacques Cartier, the source of the river, a sheet of 
water nine miles long and from one to three wide; fifty rods below was Little Lake Jacques Cartier, an irregular body about two miles across. Stretching away on every hand, bristling on the mountains and darkling in the valleys, was the illimitable spruce woods. The moss in them covered the ground nearly knee-deep, and lay like newly fallen snow, hiding rocks and logs, filling depressions, and maffling the foot. When it was dry, one could find a most delightful couch anywhere.

The spruce seems to have colored the water, which is a dark amber color, but entirely sweet and pure. There needed no better proof of the latter fact than the trout with which it abounded, and their clear and vivid tints. In its lower portions near the St. Lawrence, the Jacques Cartier River is a salmon stream, but these fish have never been found as near its source as we were, though there is no apparent reason why they should not be.

There is perhaps no moment in the life of an angler fraught with so much eagerness and impatience as when he first finds himself upon the bank of a new and long-sought stream. When I was a boy and used to go a-fishing, I could seldom restrain my eagerness after $I$ arrived in sight of the brook or pond, and must needs run the rest of the way. Then the delay in rigging my tackle was a trial my patience was never quite equal to. After I had made a few casts, or had caught one fish, I could pause and adjust my line properly. I found some remnant of the old enthusiasm still in me when $I$ 
sprang from the buckboard that afternoon and saw the strange river rushing by. I would have given something if my tackle had been rigged so that I could have tried on the instant the temper of the trout that had just broken the surface within easy reach of the shore. But I had anticipated this moment coming along, and had surreptitiously undono my rod-case and got my reel out of my bag, and was therefore a few moments ahead of my companion in making the first cast. The trout rose readily, and almost too soon we had more than enoligh for dinner, though no "rod-smashers" had been seen or felt. Our experience the next morning, and during the day and the next morning, in the lake, in the rapids, in the pools, was about the same: there was a surfeit of trout eight or ten inches long, though we rarely kept any under ten, but the big fish were lazy and would not rise; they were in the deepest water and did not like to get up.

The third day, in the afternoon, we had our first and only thorough sensation in the shape of a big trout. It came none too soon. The interest had begun to flag. But one big fish a week will do. It is a pinnacle of delight in the angler's experienco that he may well be three days in working up to, and, once reached, it is three days down to the old humdrum level again. At least it is with me. It was a dull, rainy day; the fog rested low upon the mountains, and the time hung heavily upon our hands. About three o'clock the rain slackened and wo emerged from our den, Joo going to look after 
his horse, which had eaten but little since coming into the woods, the poor creature was so disturbed by the loneliness and the black flies; I, to make preparations for dinner, while my companion lazily took his rod and stepped to the edge of the big pool in front of camp. At the first introductory cast, and when his fly was not fifteen feet from him upon the water, there was a lunge and a strike, and apparently the fisherman had hooked a bowlder. I was standing a few yards below, engaged in washing out the coffee-pail, when I heard him call out:-

"I have got him now!"

"Yes, I see you have," said I, noticing his bending pole and moveless line; "when I am through, I will help you get loose."

"No, but I'm not joking," said he; "I have got a big fish."

I looked up again, but saw no reason to change my impression, and kept on with my work.

It is proper to say that my companion was a novice at fly-fishing, never having cast a fly till upon this trip.

Again he called out to me, but, deceived by his coolness and nonchalant tones, and by the lethargy of the fish, I gave little heed. I knew very well that, if I had struck a fish that held me down in that way, I should have been going through a regular war-dance on that circle of bowlder-tops, and should have scared the game into activity if the hook had failed to wake him up. But as the farce continued I drew near. 
"Does that look like a stone or a $\log$ ?" said my friend, pointing to his quivering line, slowly cutting the current up toward the centre of the pool.

My skepticism vanished in an instant, and I could hardly keep my place on the top of the rock.

"I can feel him breathe," said the now warming fisherman; "just feel of that pole!"

I put my eager hand upon the butt, and could easily imagine $I$ felt the throb or pant of something alive down there in the black depths. But whatever it was moved about like a turtle. My companion was praying to hear his reel spin, but it gave out now and then only a few hesitating clicks. Still the situation was excitingly dramatic, and we were all actors. I rushed for the landing-net, but, being unable to find it, shouted desperately for Joe, who came hurrying back, excited before he had learned what the matter was. The net had been left at the lake below, and must be had with the greatest dispatch. In the mean time I skipped about from bowlder to bowlder as the fish worked this way or that about the pool, peering into the water to catch a glimpse of him, for he had begun to yield a little to the steady strain that was kept upon him. Presently I saw a shadowy, unsubstantial something just emerge from the black depths, then vanish. Then I saw it again, and this time the huge proportions of the fish were faintly outlined by the white facings of his fins. The sketch lasted but a twinkling; it was only a flitting shadow upon a darker background, but it gave me the profoundest Ike Walton thrill I 
ever experienced. I had been a fisher from my ear. liest boyhood. I came from a race of fishers; trout streams gurgled about the roots of the family tree, and there was a long accumulated and transmitted tendency and desire in me that that sight gratified. I did not wish the pole in my own hands; there was quite enough electricity overflowing from it and filling the air for me. The fish yielded more and more to the relentless pole, till, in about fifteen minutes from the time he was struck, he came to the surface, then made a little whirlpool where he disappeared again.

But presently he was up a second time, and lashing the water into foam as the angler led him toward the rock upon which I was perched net in hand. As I reached toward him, down he went again, and, taking another circle of the pool, came up still more exhausted, when, between his paroxysms, I carefully ran the net over him and lifted him ashore, amid, it is needless to say, the wildest enthusiasm of the spectators. The congratulatory laughter of the loons down on the lake showed how even the outsiders sympathized. Much larger trout have been taken in these waters and in others, but this fish would have swallowed any three we had ever before caught.

"What does he weigh?" was the natural inquiry of each; and we took turns "hefting" him. But gravity was less potent to us just then than usual, and the fish seemed astonishingly light.

"Four pounds," we said; but Joe said more. So we improvised a scale: a long strip of board was 
balanced across a stick, and our groceries served as weights. A four-pound package of sugar kicked the beam quickly; a pound of coffee was arded; still it went up; then a pound of tea, and still the fish had a little the best of it. But we called it six pounds, not to drive too sharp a bargain with fortune, and were more than satisfied. Such a beantiful creature! marked in every respect like a trout of six inches. We feasted our eyes upon him for half an hour. We stretched him upon the ground and admired him; we laid him across a $\log$ and withdrew a few paces and admired him; we hung him against the shanty, and turned our heads from side to side as women do when they are sclecting dress goods, the better to take in the full force of the effect.

He graced the board or stump that afternoon, and was the sweetest fish we had taken. The flesh was a deep salmon-color and very rich. We had before discovered that there were two varieties of trout in these waters, irrespective of size, - the red-fleshed and the white-fleshed, - and that the former were the better.

This success gave an impetus to our sport that carried us through the rest of the week finely. We had demonstrated that there were big trout here, and that they would rise to a fly. Henceforth big fish were looked to as a possible result of every excursion. To me, especially, the desire to at least match my companion, who had been my pupil in the art, was keen and constant. We built a raft of logs 
and upon it I floated out upon the lake, whipping its waters right and left, morning, noon, and night. Many fine trout came to my hand, and were released because they did not fill the bill.

The lake became my favorite resort, while my companion preferred rather the shore or the long still pool above, where there was a rude makeshift of a boat, made of common box-boards.

Upon the lake you had the wildness and solitude at arm's length, and could better take their look and measure. You became something apart from them; you emerged and had a vantage ground like that of a mountain peak, and could contemplate them at your ease. Seated upon my raft and slowly carried by the current or drifted by the breeze, I had many a long, silent look into the face of the wilderness, and found the communion good. I was alone with the spirit of the forest-bound lakes and felt its presence and magnetism. I played hide-andseek with it about the nooks and corners, and lay in wait for it upon a little island crowned with a clump of trees that was moored just to one side the current near the head of the lake.

Indeed, there is no depth of solitude that the mind does not endow with some human interest. As in a dead silence the ear is filled with its own murmur, so amid these aboriginal scenes one's feelings and sympathies become external to him, as it were, and he holds converse with them. Then a lake is the ear as well as the eye of a forest. It is the place to go to listen and ascertain what sounds are abroad 
in the air. They all run quickly thither and report. If any creature had called in the forest for iniles about, I should have heard it. At times I could hear the distant roar of water off beyond the outlet of the lake. The sound of the vagrant winds purring here and there in the tops of the spruces reached my ear. A breeze would come slowly down the mountain, then strike tho lake, and I could see its footsteps approaching by the changed appearance of the water. How slowly the winds move at times, sauntering like one on a Sunday walk! A breeze always enlivens the fish; a dead calm and all pennants sink, your activity with your fly is ill-timed, and you soon take the hint and stop. Becalmed upon my raft, I observed, as I have often done before, that the life of Nature ebbs and flows, comes and departs, in these wilderness scenes; one moment her stage is thronged and the next quite deserted. Then there is a wonderful unity of movement in the two elements, air and water. When there is much going on in one, there is quite sure to be much going on in the other. You have been casting, perhaps, for an hour with scarcely a jump or any sign of life anywhere about you, when presently the breeze freshens and the trout begin to respond, and then of a sudden all the performers rush in: ducks come sweeping by; loons laugh and wheel overhead, then approach the water on a long, gentle incline, plowing deeper and deeper into its surface, until their momentum is arrested, or converted into foam; the fish hawk screams; the bald eagle goes flapping 
by, and your eyes and hands are full. Then the tide ebbs, and both fish and fowl are gone.

Patiently whipping the waters of the lake from my rude float, I became an object of great interest to the loons. I had never seen these birds before in their proper habitat, and the interest was mutual. When they had paused on the Hudson during their spring and fall migrations, I had pursued them in my boat to try to get near them. Now the case was reversed; I was the interloper now, and they would come out and study me. Sometimes six or eight of them would be swimming about watching my movements, but they were wary and made a wide circle. One day one of their number volunteered to make a thorough reconnoissance. I saw him leave his comrades and swim straight toward me. He came bringing first one eye to bear upon me, then the other. When about half the distance was passed over he began to waver and hesitate. To encourage him I stopped casting, and taking off my hat began to wave it slowly to and fro, as in the act of fanning myself. This started him again, this was a new trait in the creature that he must scrutinize more closely. On he came, till all his markings were distinctly seen. With one hand I pulled a little revolver from my hip pocket, and when the loon was about fifty yards distant, and had begun to sidle around me, I fired: at the flash I saw two webbed feet twinkle in the air, and the loon was gone! Lead could not have gone down so quickly. The bullet cut across the circles where he 
disappeared. In a few moments he reappeared a couple of hundred yards away. "Ha-ha-ha-a-a," said he, "ha-ha-ha-a-a," and "ha-ha-ha-a-a," said his comrades, who had been looking on ; and "ha-haha-a-a," said we all, echo included. He approached a second time, but not so closely, and when I began to creep back toward the shore with my heavy craft, pawing the water first upon one side, then the other, he followed, and with ironical laughter witnessed my efforts to stem the current at the head of the lake. I confess it was enough to make a more solemn bird than the loon laugh, but it was no fun for me, and generally required my last pound of steam.

The loons flew back and forth from one lake to the other, and their voices were about the only notable wild sounds to be heard.

One afternoon, quite unexpectedly, I struck my big fish in the head of the lake. I was first advised of his approach by two or three trout jumping clear from the water to get out of his lordship's way. The water was not deep just there, and he swam so near the surface that his enormous back cut through. With a swirl he swept my fly under and turned.

My hook was too near home, and my rod too near a perpendicular to strike well. More than that, my presence of mind came near being unhorsed by the sudden apparition of the fish. If I could have had a moment's notice, or if I had not seen the monster, I should have fared better and the fish worse. I struck, but not with enough decision, and, before I could reel up, my empty hook came back. 'Tho 
trout had carried it in his jaws till the fraud was detected, and then spat it out. $\mathrm{He}$ came a second time and made a grand commotion in the water, but not in my nerves, for I was ready then, but failed to take the fly, and so to get his weight and beauty in these pages. As my luck failed me at the last, I will place my loss at the full extent of the law, and claim that nothing less than a ten-pounder was spirited away from my hand that day. I might not have saved him, netless as I was upon my cumbrous raft; but I should at least have had the glory of the fight, and the consolation of the fairly vanquished.

These trout are not properly lake trout, but the common brook trout. The largest ones are taken with live bait through the ice in winter. The Indians and the habitans bring them out of the wood from here and from Snow Lake, on their toboggans, from two and a half to three feet long. They have kinks and ways of their own. About half a mile above camp we discovered a deep oval bay to one side the main current of the river, that evidently abounded in big fish. Here they disported themselves. It was a favorite feeding ground, and late every afternoon the fish rose all about it, making those big ripples the angler delights to see. A trout, when he comes to the surface, starts a ring about his own length in diameter; most of the rings in the pool, when the eye caught them, were like barrel hoops, but the haughty trout ignored all our best efforts; not one rise did we get. We were told of this pool on our return to Quebec, and that other 
anglers had a similar experience there. But occasionally some old fisherman, like a great advocate who loves a difficult case, would set his wits to work and bring into camp an enormous trout taken there.

I had been told in Quebec that I would not see a bird in the woods, not a feather of any kind. But I knew I should, though they were not numerous. I saw and heard a bird nearly every day, on the tops of the trees about, that I think was one of the crossbills. The kingfisher was there ahead of us with his loud clicking reel. The osprey was there, too, and I saw him abusing the bald eagle, who had probably just robbed him of a fish. The yellow-rumped warbler I saw, and one of the kinglets was leading its lisping brood about through the spruces. In every opening the white-throated sparrow abounded, striking up his clear sweet whistle, at times so lond and sudden that one's momentary impression was that some farm boy was approaching, or was secreted there behind the logs. Many times, amid those primitive solitudes, I was quite startled by the human tone and quality of this whistle. It is little more than a beginning; the bird never seems to finish the strain suggested. The Canada jay was there also, very busy about some important private matter.

One lowery morning, as I was standing in camp, I saw a lot of ducks borne swiftly down by the current around the bend in the river a few rods above. They saw me at the same instant and turned toward the shore. On hastening up there, I found the oll bird rapidly leading her nearly grown brood through 
the woods, as if to go around our camp. As I pursued them they ran squawking with outstretched stubby wings, scattering right and left, and seeking a hiding-place under the logs and débris. I captured one and carried it into camp. It was just what Joe wanted; it would make a valuable decoy. So he kept it in a box, fed it upon oats, and took it out of the woods with him.

We found the camp we had appropriated was a favorite stopping-place of the carmen who hauled in supplies for the gang of two hundred road-builders. One rainy day near nightfall no less than eight carts drew up at the old stable, and the rain-soaked drivers, after picketing and feeding their horses, came down to our fire. We were away, and Joe met us on our return with the unwelcome news. We kept open house so far as the fire was concerned; but our roof was a narrow one at the best, and one or two leaky spots made it still narrower.

"We shall probably sleep out-of-doors to-night," said my companion, "unless we are a match for this posse of rough teamsters."

But the men proved to be much more peaceably disposed than the same class at home; they apologized for intruding, pleading the inclemency of the weather, and were quite willing, with our permission, to take up with pot-luck about the fire and leave us the shanty. They dried their clothes upon poles and logs, and had their fun and their bantering amid it all. An Irishman among them did about the only growling; he invited himself into our quarters, 
and before morning had Joe's blanket about him in addition to his own.

On Friday we made an excursion to Great Lake Jacques Cartier, paddling and poling up the river in the rude box-boat. It was a bright, still morning after the rain, and everything had a new, fresh appearance. Expectation was ever on tiptoe as each turn in the river opened a new prospect before us. How wild, and shaggy, and silent it was! What fascinating pools, what tempting stretches of trouthaunted water! Now and then we would catch a glimpse of long black shadows starting away from the boat and shooting through the sunlit depths. But no sound or motion on shore was heard or seen. Near the lake we came to a long, shallow rapid, when we pulled off our shoes and stockings, and, with our trousers rolled above our knees, towed the boa'; up it, wincing and eringing amid the sharp, slippery stones. With benumbed feet and legs we reached the still water that forms the stem of the lake, ard presently saw the arms of the wilderness open and t'ie long deep blue expanse in their embrace. We rested and bathed, and gladdened our eyes with the singularly beautiful prospect. The shadows of summer clouds were slowly creeping up and down the sides of the mountains that hemmed it in. On the far eastern shore, near the head, banks of what was doubtless white sand shone dimly in the sun, and the illusion that there was a town nestled there haunted my mind constantly. It was like a section of the Hudson below the Highlands, except that 
these waters were bluer and colder, and these shores darker, than even those Sir Hendrik first looked upon; but surely, one felt, a steamer will round that point presently, or a sail drift into view! We paddled a mile or more up the east shore, then across to the west, and found such pleasure in simply gazing upon the scene that our rods were quite neglected. We did some casting after a while, but raised no fish of any consequence till we were in the outlet again, when they responded so freely that the "disgust of trout" was soon upon us.

At the rapids, on our return, as I was standing to my knees in the swift, cold current, and casting into a deep hole behind a huge bowlder that rose four or five feet above the water amidstream, two trout, one of them a large one, took my flies, and, finding the fish and the current united too strong for my tackle, I sought to gain the top of the bowlder, in which attempt I got wet to my middle and lost my fish. After I had gained the rock, I could not get away again with my clothes on without swimming, which, to say nothing of wet garments the rest of the way home, I did not like to do amid those rocks and swift currents; so, after a vain attempt to communicate with my companion above the roar of the water, I removed my clothing, left it together with my tackle upon the rock, and by a strong effort stemmed the current and reached the shore. The boat was a hundred yards above, and when I arrived there my teeth were chattering with the cold, my feet were numb with bruises, and the black flies were making 
the blood stream down my back. We hastened back with the boat, and, by wading out into the current again and holding it by a long rope, it swung around with my companion aboard, and was held in the eddy behind the rock. I clambered up, got my clothes on, and we were soon shooting down stream toward home; but the winter of discontent that shrouded one half of me made sad inroads upon the placid feeling of a day well spent that enveloped the other, all the way to camp.

That night something carried off all our fish, doubtless a fisher or lynx, as Joe had seen an animal of some kind about camp that day.

I must not forget the two red squirrels that frequented the camp during our stay, and that were so tame they would approach within a few feet of us and take the pieces of bread or fish tossed to them. When a particularly fine piece of hard-tack was secured they would spin off to their den with it somewhere near by.

Caribou abound in these woods, but we saw only their tracks; and of bears, which are said to be plentiful, we saw no signs.

Saturday morning we packed up our traps and started on our return, and found that the other side of the spruce-trees and the vista of the lonely roal going south were about the same as coming north. But we understood the road better and the buckboard better, and our load was lighter, hence tho distance was more easily accomplished.

I saw a solitary robin by the roadside, and won. 
dered what could have brought this social and halfdomesticated bird so far into these wilds. In La Grande Brûlure, a hermit thrush perched upon a dry tree in a swampy place and sang most divinely. We paused to listen to his clear, silvery strain poured out without stint upon that unlistening soliEnde. I was half persuaded I had heard him before on first entering the woods.

We nooned again at No Man's Inn on the banks of a trout lake, and fared well and had no reckoning to pay. Late in the afternoon we saw a lonely pedestrian laboring up a hill far ahead of us. When he heard us coming he leaned his back against the bank, and was lighting his pipe as we passed. $\mathrm{He}$ was an old man, an Irishman, and looked tired. $\mathrm{He}$ had come from the farther end of the road, fifty miles distant, and had thirty yet before him to reach town. He looked the dismay he evidently felt when, in answer to his inquiry, we told him it was yet ten miles to the first house, La Chance's. But there was a roof nearer than that, where he doubtless passed the night, for he did not claim hospitality at the cabin of $\mathrm{La}$ Chance. We arrived there oetimes, but found the "spare bed" assigned to other guests; so we were comfortably lodged upon the haymow. One of the boys lighted us up with a candle and made level places for us upon the hay.

La Chance was one of the game wardens, or con. stables appointed by the government to see the game laws enforced. Joe had not felt entirely at his ease about the duck he was surreptitiously taking to 
town, and when, by its "quack, quack," it called upon La Chance for protection, he responded at once. Joe was obliged to liberate it then and there, and to hear the law read and expounded, and bo threatened till he turned pale beside. It was evident that they follow the home government in the absurd practice of enforcing their laws in Canada. La Chance said he was under oath not to wink at or permit any violation of the law, and seemed to think that made a difference.

We were off early in the morning, and before we had gone two miles met a party from Quebec who must have been driving nearly all night to give the black flies an early breakfast. Before long a slow rain set in; we saw another party who had taken refuge in a house in a grove. When the rain had become so brisk that we began to think of seeking shelter ourselves, we passed a party of young m(n) and boys - sixteen of them - in a cart turning back to town, water-soaked and heavy (for the poor hor:s had all it could pull), but merry and good-naturesl. We paused a while at the farmhouse where we had got our hay on going out, were treated to a drink of milk and some wild red cherries, and when the rain slackened drove on, and by ten o'clock saw the city eight miles distant, with the sun shining upon its steep tinned roofs.

The next morning we set out per steamer for the Saguenay, and entered upon the second phase of ou. travels, but with less relish than wo could have wished. Scenery hunting is the least satisfying pur- 
suit I have ever engaged in. What one sees in his necessary travels, or doing his work, or going a-fishing, seems worth while, but the famous view you go out in cold blood to admire is quite apt to elude you. Nature loves to enter a door another hand has opened; a mountain view, or a waterfall, I have noticed, never looks better than when one has just been warmed up by the capture of a big trout. If we had been bound for some salmon stream up the Saguenay, we should perhaps have possessed that generous and receptive frame of mind - that open house of the heart - which makes one "eligible to any good fortune," and the grand scenery would have come in as fit sauce to the salmon. An adventure, a bit of experience of some kind, is what one wants when he goes forth to admire woods and waters, something to create a draught and make the embers of thought and feeling brighten. Nature, like certain wary game, is best taken by seeming to pass by her intent on other matters.

But without any such errand, or occupation, or indirection, we managed to extract considerable satisfaction from the view of the lower St. Lawrence and the Saguenay.

We had not paid the customary visit to the falls of the Montmorenci, but we shall see them after all, for before we are a league from Quebec they come into view on the left. A dark glen or chasm there at the end of the Beauport Slopes seems sud. denly to have put on a long white apron. By intently gazing, one can see the motion and falling of 
the water, though it is six or seven miles away. There is no sign of the river above or below but this trembling white curtain of foam and spray.

It was very sultry when we left Quebec, lut about noon we struck much clearer and cooler air, and soon after ran into an immense wave or puff of fog that came drifting up the river and set all the fog-guns booming along shore. We were soon through it into clear, crisp space, with room enough for any eye to range in. On the south the shores of the great river appear low and uninteresting, but on the north they are bold and striking enough to mako it up, - high, scarred, unpeopled mountain rangres the whole way. The points of interest to the eye in the broad expanse of water were the white porpoises that kept rolling, rolling in the distance, all day. They came up like the perimeter of a great wheel that turns slowly and then disappears. From mid-forenoon we could see far ahead an immense column of yellow smoke rising up and flattening out upon the sky and stretching away beyond the horizon. Its form was that of some aquatic plant that shoots a stem up through the water, and spreads its broad leaf upon the surface. This smoky lily-pad must have reached nearly to Maine. It proved to bo in the Indian country in the mountains beyond the mouth of the Saguenay, and must have represented an immense destruction of forest timber.

The steamer is two hours crossing the St. Lawrence from Rivière du Loup to Tadousac. The Saguenay pushes a broad sweep of dark blue water 
down into its mightier brother that is sharply defined from the deck of the steamer. The two rivers seem to touch, but not to blend, so proud and haughty is this chieftain from the north. On the mountains above Tadousac one could see banks of sand left by the ancient seas. Naked rock and sterile sand are all the Tadousacker has to make his garden of, so far as I observed. Indeed, there is no soil along the Saguenay until you get to Ha-ha Bay, and then there is not much, and poor quality at that.

What the ancient fires did not burn the ancient seas have washed away. I overheard an English resident say to a Yankee tourist, "You will think you are approaching the end of the world up here." It certainly did suggest something apocryphal or antemundane, - a segment of the moon or of a cleft asteroid, matter dead or wrecked. The world-builders must have had their foundry up in this neighborhood, and the bed of this river was doubtless the channel through which the molten granite flowed. Some mischief-loving god has let in the sea while things were yet red-hot, and there has been a time here. But the channel still seems filled with water from the mid-Atlantic, cold and blue-black, and in places between seven and eight thousand feet deep (one and a half miles). In fact the enormous depth of the Saguenay is one of the wonders of physical geography. It is as great a marvel in its way as Niagara.

The ascent of the river is made by night, and 
the traveler finds himself in Ha-ha Bay in the morning. The steamer lies here several hours before starting on her return trip, and takes in large quantities of white birch wood, as she does also at Tadousac. The chief product of the country seemed to be huckleberries, of which large quantities are shipped to Quebec in rude board boxes holding about a peck each. Little girls came aboard or lingered about the landing with cornucopias of birch-bark filled with red raspberries; five cents for about half a pint was the usual price. The village of St. Alphonse, where the steamer tarries, is a cluster of small, humble dwellings dominated, like all Canadian villages, by an immense church. Usually the church will hold all the houses in the village; pile them all up and they would hardly-equal it in size; it is the one conspicuous object, and is seen afar; and on the various lines of travel one sees many more priests than laymen. They appear to be about the only class that stir about and have a good time. Many of the houses were covered with birch-bark, - the canoe birch, - held to its place by perpendicular strips of board or split poles.

A man with a horse and a buckboard persuaded us to give him twenty-five cents each to take us two miles up the St. Alphonse River to see the salmon jump. There is a high saw-mill dam there which every salmon in his upward journey tries his hand at leaping. A raceway has been constructed around the dam for their benefit, which it seems they do not use till they have repeatedly tried to scalo the 
dam. The day before our visit three dead fish were found in the pool below, killed by too much jumping. Those we saw had the jump about all taken out of them; several did not get more than half their length out of the water, and occasionally only an impotent nose would protrude from the foam. One fish made a leap of three or four feet and landed on an apron of the dam and tumbled helplessly back; he shot up like a bird and rolled back like a clod. This was the only view of salmon, the buck of the rivers, we had on our journey.

It was a bright and flawless midsummer day that we sailed down the Saguenay, and nothing was wanting but a good excuse for being there. The river was as lonely as the St. John's road; not a sail or a smokestack the whole sixty-five miles. The scenery culminates at Cape Trinity, where the rocks rise sheer from the water to a height of eighteen hundred feet. This view dwarfed anything I had ever before seen. There is perhaps nothing this side the Yosemite chasm that equals it, and, emptied of its water, this chasm would far surpass that famous cañon, as the river here is a mile and a quarter deep. The bald eagle nests in the niches in the precipice secure from any intrusion. Immense blocks of the rock had fallen out, leaving areas of shadow and clinging overhanging masses that were a terror and fascination to the eye. There was a great fall a few years ago, just as the steamer had passed from under and blown her whistle to awake the echoes. The echo came back, and with it a part of the moun- 
tain that astonished more than it delighted the lookers-on. The pilot took us close around the base of the precipice that we might fully inspect it. And here my eyes played me a trick the like of which they had never done before. One of the boys of the steamer brought to the forward deck his hands full of stones, that the curious ones among the passengers might try how easy it was to throw one ashore. "Any girl ought to do it," I said to myself, after a man had tried and had failed to clear half the distance. Seizing a stone, I cast it with vigor and confidence, and as much expected to see it smite the rock as I expected to live. "It is a good while getting there," I mused, as I watched its course: down, down it went; there, it will ring upon the granite in half a breath; no, down - into the water, a little more than half way! "Has my arm lost its cunning?" I said, and triod again and again, but with like result. The eye was completely at fault. There was a new standard of size before it to which it failed to adjust itself. The rock is so enormous and towers so above you that you get the impression it is much nearer than it actually is. When the eye is full it says, "Here we are," and the hand is ready to prove the fact; but in this case there is an astonishing discrepancy between what the eye reports and what the hand finds out.

Cape Eternity, the wife of this colossus, stands across a chasm through which flows a small tributary of the Saguenay, and is a head or two shorter, as becomes a wife, and less rugrged and broken in outline. 
From Rivière du Loup, where we passed the night and ate our first "Tommy-cods," our thread of travel makes a big loop around New Brunswick to St. John, thence out and down through Maine to Boston, - a thread upon which many delightful excur sions and reminiscences might be strung. We trave ersed the whole of the valley of the Metapedia, and passed the doors of many famous salmon streams and rivers, and heard everywhere the talk they inspire; one could not take a nap in the car for the excitement of the big fish stories he was obliged to overhear.

The Metapedia is a most enticing-looking stream; its waters are as colorless as melted snow; I could easily have seen the salmon in it as we shot along, if they had come out from their hiding-places. It was the first white-water stream we had seen since leaving the Catskills; for all the Canadian streams are black or brown, either from the iron in the soil or from the leechings of the spruce swamps. But in New Brunswick we saw only these clear, silvershod streams; I imagined they had a different ring or tone also. The Metapedia is deficient in good pools in its lower portions; its limpid waters flowing with a tranquil murmur over its wide, evenly paved bed for miles at a stretch. The salmon pass over these shallows by night and rest in the pools by day. The Restigouche, which it joins, and which is a famous salmon stream and the father of famous salmon streams, is of the same complexion and a delight to look upon. There is a noted pool wher 
the two join, and one can sit upon the railroad bridge and count the noble fish in the lucid depths below. The valley here is fertile, and has a cultivated, well-kept look.

We passed the Jacquet, the Belledune, the Nepissisquit, the Miram....i ? 'sappy retreat") in the night, and have only their bird-call names to report. 



\section{INDEX}

A STEMONE, 2.

Angler, a born, 98-100; eagerness of the, 204, 205.

Arbutus, 2.

Asters, 6.

Audubon, John James, 125, 144, 145.

Aurora borealis, an, 108, 109.

Balsam Lake, 118-122.

Barrington, Daines, his table of English song-birds, 130, 131.

Basswood, or linden, 5.

Bear, black (Ursus americanus), 116, 219.

Beaverkill, the, 101, 112, 113 ; trouting on, 116-118.

Bee. See Bumblebee and Honeybee.

Berries, 225.

Berrying, 60-62.

Big Ingin River, 101.

Birch, yellow, 159, 160.

Birds, eyes of, 43,48 ; imperfect singers among, 115, 116; human significance of, 125,126 ; songs of English, 129-133; relative pugnaciousness of English and American, 134 ; species common to Europe and America, 134 ; small and large editions of various species of, 143-147; their ingenuity in the concealment of their nests, $186,187$.

Birds of prey, 135.

Biscuit Brook, 112, 114, 172.

Blackbird, European, 133 ; notes of, 132.

Blackbird, red-winged. See Starling, red-shouldered.

Bloodroot, 2.

Bluebird (Sialia sialis), struggllng with a cicada, 29, 30; courting, 31 ; cares of housekeeping, 31,32 ; and screech owl, 50, 131; notes of, 31,32 ; nest of, 31,32 .

Blunder-heads, 171.
Bobolink (Dolichonyz oryzirorus) $61,97,116$; song of, 57,125 .

Boy, 171.

Brook8. See Trout streams.

Buckwheat, 6.

Bumble-bee, 4, 61.

Bunting, Luropean, notes of, 132.

Bunting, indigo. See Indigo-bird.

Bunting, snow, or snowtlake (Plectrophenax nivalis), 13 .

Butcher-bird, or northern shrike (Lanius borealis), 134: appearance and habits of, 135-142 ; note of, 140-142. See Shrike.

Buttercup, 97.

Camp, a thunder-storm in, 8i-91; in the rain, 102-106; books in, 161.

Camp-fire, the, 159, 160.

Camping, by trout stream and lake, $101-123$; in a log stable, $105-112$; pleasures and discomforts of, 12:, 123 ; in the Catskills, 149-175; thoughts of the camper, 160 ; in Canada, 203-219.

Canada, an excursion in, 159-229; dwelling-houses in, 191, 2.25; churches in, 225.

Cape Eternity, $22 \%$.

Cape Trinity, 226, 227.

Caribou (Rangifer tarandus var. caribou), 219.

Catbird (Galeoscoptes carolinensis), song of, 126.

Catfish aud snake, $47,48$.

Catnip, 4.

Catskill Mountains, camping in, 149-175.

Cattle, in Canada, 196.

Cedar-bird, or cedar waxwing ( $A \mathrm{~m}$ pelis cedrorum), a nmall edition of the Bohemian warwing, 143; plur mage of, 1H; notes of, 1 H.

Chickadee (I'arus atricaysillus), 38. notes of, 126.

Chipmunk (Tumias striabus), fright 
ened by a shrike, 138, 139 ; stealing strawberries, 179,180 ; playing tag, 183; never more than one jump from home, 183.

Clouds, natural history of, 78-80 ; rain-clouds and wind-clouds, 8587.

clover, red, 4.

Clover, white, 3.

Coon. See Raccoon.

Corn, Indian, 4.

Corydalis, 2.

Crossbills, 134.

Crow, American (Corvus americanus), 48, 126, 187 ; notes of, 187.

Crow, fish (Corvus ossifragus), a sneak thief, 187.

Cuckoo (Coccyzus sp.), parents, eggs, and young, 36,37 ; breeding habits of, 37,$46 ;$ appearance and habits of, 126-129; notes of, 127, 128 ; nest of, $36,37,127,129$.

Cuckoo, European, 126-129 ; in literature, 126-129; notes of, 127129.

Daisy, ox-eye, $59,60$.

Dandelion, 4.

Deer, Virginia (Cariacus virginianus), 116.

Deiaware River, 100, 101.

Dove, mourning (Zenaidura macroura), notes of, 125.

Drcught, 72-75.

Ducks, wild, voices of, 132 ; 211, $215,216$.

Eagle, bald (Halicëtus leucocephalus), 211, 215; nest of, 226.

Esopus Creek, 101.

Eyes, of man, 27, 28, 43; of birds, 43.

Farmer, an observing, 34-40.

Farmers, their dependence on the weather, 65 ; weather-wisdom of, $84,86$.

Fieldfare, 133 ; notes of, 132.

Finch, purple (Carpodacus purpureus), the alter ego of the pine grosbeak, 145; song of, 145.

Fishing. See Trout-fishing.

Flicker. See High-hole.

Flies, black, 200, 218 .

Flycatcher, great crested (Myiarchus crinitus), 134 ; nest of, 40.

Porest, a spruce, 200,201 ; a burnt, 202.

fox, red (Vulpes vulpes, var. fulvus), bark of, 131 ; 135, 177.
French Canadians, 196-199, 216, 221.

Ghost story, a, 163, 164 .

Girl's voice, a, 172.

Goethe, on the weather, 67, 68, 79.

Goldenrod, 6 .

Goldfinch, American (Spinus tristis), a shrike in a flock of, 136-138.

Goose, wild or Canada (Branta can. adensis), notes of, 126, 132.

Graude Brûlure, La, 202.

Greenfinch, 134.

Grosbeak, blue (Guiraca carulea), its resemblance to the indigo-bird, 146,147 ; song of, 146,147 ; nest of, 146 .

Grosbeak, pine (Pinicola enucleator), 134 ; appearance and habits of, 145, 146; song of, 145.

Grouse, ruffed. See Partridge.

Grouse, spruce or Canada (Dendragapus canadensis), 201.

Guide, a Canadian, 195, 196, 198, $216,220,221$.

Hawk, worried by the kingbird, 39, 136. See Hen-hawk.

Hawk, chicken, a provident, 49.

Hawk, fish, or American osprey (Pandion haliaëtus carolinensis), $211,215$.

Hen-hawk, a love passage, 38 ; incubating habits, 39 .

Hepatica, 2.

Highfall Brook, 112.

High-hole, or golden-shafted woodpecker, or flicker (Colaptes auratus), a household of, 32-34; a tame young one, 34-36; nest of, 32-34.

Honey, as an article of food, 22, 23; with the ancients and in mythology, 23-25; of various countries, 25,26 .

Honey-bee, gathering honey and pollen, 1-7 ; wax-making, 7, 8 ; life of the drone, $8-9$; life of the queen, $9-13$; democratic govern. ment, 11 ; description of queen and drone, 12 ; swarming, 13-21; wildness of, 14 ; favorite hives, 21 ; mortality of, 21,22 ; acuteness of sight, 22.

Honey-locust, 3.

Horse-fly, 200.

Hummingbird, ruby-throated (Trochilus colubris), strange death of a, 38 ; nest of, 187.

Hyla, Pickering's, in the woods, 44. 
Indigo-blrd, or indigo bunting (Passerina cyanea), a petit duplicate of the blue grosbeak, 146, 147; song of, 146 ; nest of, 147 .

Jackdaw, nest of, 133.

Jacques Cartier River, trouting on, 203-219.

Jay, blue (Cyanocilta cristata), 48; worrying a screech owl, 49,50.

Jay, Canada (Perisoreus canadensis), 215.

Jay, European, notes of, 132.

Junco, slate-colored. See Snowbird.

Kingbird (Tyrannus tyrannus), worrying hawks, $39,134,187$.

Kingfisher, belted (Ceryle alcyon), 165,189 ; notes of, 189,215 ; nest of, 189 .

Kinglet (Regulus sp.), 215.

La Chance, 197-199, 220, 221.

Lake, nature as seen from a, 210 , 211 ; life in and about $a, 211,212$.

Lake Jacques Cartier, Great, 203 ; an excursion to, $217,218$.

Lake Jacques Cartier, Little, 204; trout-fishing in, 210-214.

Lake Memphremagog, 190.

Lake St. John, 194, 195.

Lark. See Skylark.

Lark, shore or horned (Otocoris alpestris), 134.

Ledges, the fascination of, 178.

Lily, spotted, 97.

Linden. See Basswood.

Locusts, as an article of food, 25.

Longspur, Lapland (Calcarius lapponicus), 134.

Loon (Urinalor imber), 211-213 ; laughter of, 208, 211, 213.

Maiden, a backwoods, 173, 174.

Maple, red, 2.

Maple, sugar, 2.

Marigold, marsh, 97.

Marmot. See Woodchuck.

MLeadowlark (Sturnella magna), 97.

Metapedia River, 228.

Midges, 107, 108.

Mockingbird (Mimus polyglottos), 133 ; song of, 125,131 .

Montmorenci, Falls of, 222, 223.

Moose (Alce alces), 202.

Mlorancy River, 202.

Mountains, poetry of, 157, 158.

Bouse, cominon house (Mus musculus), 134.
Neversink Rlver, trouting on, 101 114; trouting on the Finst Brauch of, 166.

New 13runswick, foumny through, 228,229 ; strenms of, '2, th.

Nightingale, notes of, 131, 132.

Observation, powers and habits of, $27,2 \times, 43-47$.

Oriole, Baltimore (Ictcrus galbula), nest of, 28.

Osprey, American. See Hawk, fish. Ouzel, ring, 133.

Oven-bird (Seiurus aurocopillus), 165.

Owl, screech (Megascops asio), worried by other birds, 49,50 ; in captivity, 50, 51 ; wail of, $1 G 4$.

Panther, American (Felis concolor), cry of, 131.

Partridge, or ruffed grouse (Bonasa umbellus), 42, 177.

Peakamoose, 158.

Pewee, wood (Contopus virens), notes of, 126.

Phobe-bird (Sayornis phabe), 151, 178 ; nest of, 178 .

Pigeon, passenger (Ectopistes migratorius), 142, 170, 201; nests of, $102,170,171$.

Pipit, American, or titlark (Anthus pensilvanicus), 45.

Porcupine, Canala (I:rethizon dorsntus), adventure with a, 103-111; description of, 111 ; his armor of quills, 111, 112 ; at Balsam Lake, $121,168$.

Porpoise, white, 223.

Quebec, 192-134.

Raccoon, or coon (Procyon lolor), voice of, 132 ; den of, 177.

Rain, waves and pulsations of, 63 : history of, 63,70 ; relaxing effor of, 71 inecessary to the mind, 72 ; after drought, 75,76 ; Importance to man of an abundance, 77 ; curious things reported to have falle $\mathrm{n}$ in, 77,78 ; the formation of, 78-80, storms, 80-83; effect of electricity on, 82 ; in winter and spring, $8:, 83 ;$ sigms of, $84-8 \% ;$ in camp, 102-10\%. See Thunderstorms and Westher.

Raspherry, red, 3, 23.

Rat, 135,170 .

Rat, wood (Neoloma Roridana) 169,170 . 
Redpoll (Acanthis linaria), 45, 134. Redstart, European, nest of, 133.

Redwing, 133.

Restigouche River, 228.

Rivière du Loup, 223, 228.

Robin, American (Merula migra. toria), 219 ; notes of, $83,126$.

Robin redbreast, song of, 131 .

Rondout Creek, 101 ; camping and trouting on, 150-164.

Rose, 4.

Rye, 4.

Saguenay River, scenery of, 221227.

St. Alphonse, 225.

St. Lawrence, 191, 192 ; down the, 221-224.

Salmon, 225, 226, 228.

Sapsucker, yellow - bellied. See Woodpecker, yellow-bellied.

Scenery-hunting, 221, 222.

Schoolhouse, a country, 174.

Shakespeare, quotations from, 129, 158 ; power and beauty in his poetry, 157, 158.

Shanly, c. D., his poem The Walker of the Snow, 161-163.

Shrike (Lanius sp.), 38.

Shrike, northern. See Butcherbird.

silkweed, 6.

Skunk (Mephitis mephitica), den of, 177.

8kylark, song of, 130.

Snake, and catfish, 46-48.

Snapdragon, 6.

Snow, a sign of, 86.

Snowbird, or slate-colored funco (Junco hyemalis), 136, 170.

Snowflake. See Bunting, snow.

Bparrow, English (Passer domesticus), a comedy, 28, 29; 130, 131, 134 ; notes of $130,132$.

Sparrow, reed, song of, 130.

Sparrow, song (Melospiza fasciata), song of, 125.

Sparrow, white-throated (Zonotrichia albicollis), song of, 198, 215.

Sparrows, songs of, 130.

Spring-beauty, 2.

Spruce, a Canadian forest of, 200, 201.

Squirrel, gray (Sciurus carolinensis, var. leucotis), 44.

Bquirrel, red (Sciurus hudsonicus), 168,169 ; playing tag, $183 ; 219$.

Starling, European, notes of, 132 ; nest of, 133.

Starling, red-shouldered, or red. Vireo, song of, 125. winged blackbird (Agelaius pho niceus), 97.

Strawberries, Dr. Parr and, 53 ; Dr. Boteler on, 53 ; praise of, $53-55$; odor of, 55 ; Downer, 55, 56, 64; Wilson, 56 ; wild, $57-61,179,180$, 196 ; alpine, 59 ; cultivation of, 63,64 .

Sumach, 6.

Swallow, an albino, 37.

Swallows, on damp days, 38,39 .

Swift, European, notes of, 132.

Tadousac, 223, 224.

Tanager, scarlet (Piranga erythroa melas), song of, 126 .

Thoreau, Henry D., 78; quotation from, 141, 142.

Throstle, 133.

Thrush, hermit (Turdus aonalasch. kce pallasii), 115, 116; song of, $125,220$.

Thrush, missel, 134; pugnaciousness of, 133 ; notes of, 132 .

Thrush, White's, 133.

Thrush, wood (Turdus mustelinus), song of, 125.

Thunder-storms, 82 ; in the woods, $87-91$.

Titlark. See Pipit, American.

Tree-toads, young, 78 .

Trout, brook, markings of, 93 ; of the Neversink, 101; cannibals, 113,114 ; of the Beaverkill, 117 ; jumping, 119,120 ; of Balsam Lake, 120, 121; 152 ; spawning of, 154 ; of the Catskill waters, 154 , 155 ; an unsuccessful fight with a, 155,156 ; 202 ; a six-pound, 205209 ; two varieties in Jacques Cartier River, 209; 214, 215.

Trout-fishing, as an introduction to nature, 93,94 ; the heart the proper bait in, 98,99 ; on the Neversink, 101-114; on the Beaverkill, 116-118; in Balsam Lake, 119, 120 ; pleasures and discomforts of an excursion, 122, 123; on the Rondout, 153-156; on the East Branch of the Neversink, 166; in Canada, 201, 204-219; catching a six-pounder, 205-209.

Trout streams, beauties of, 94 ; the ideal, 97,98 ; at the head waters of the Delaware, 100,101 ; clearness of, 152 ; thriving only in the woods, 203.

Violets, 2, 
Vireo, red-eyed (Vireo olvaceus), soug of, 167.

Walker of the Snow, The, by C. D. Shanly, 161-163.

Walking, benefits of, 175 .

Wallkill River, 101.

Warbler, Blackburnlan (Dendroica blackburniae), 186.

Warbler, black-throated blue (Dendroica corrulescens), 165; finding the nest and young of, 180-186; notes of, 181, 182, 184; nest of, 180-186.

Warbler, Canada (Sylvania canadensis), 165, 186.

Warbler, chestnut-sided (Dendroica pensylvanica), 165, 186.

Warbler, mourning (Geolhlypis philadelphia), 107, 186.

Warbler, yellow-rumped or myrtle (Dendroica coronata), rescue of a, $122 ; 215$.

Water, its importance in nature and in the life of man, 69-71.

Water-wagtail, small, or waterthrush (Seiurus noveboracensis), 107.

Waxwing, Bohemian (Ampelis garrulus), 143, 144.

Waxwing, cedar. See Cedar-bird.

Weather, the, the farmer's dependence on, 65; human changeablenese of, 65,66 ; getting into a rut,
66,67 ; In liternture, 67,68 ; the law of alteruation $\mathrm{In}, 65$; dry, 72 75 ; Jaws of, 83-87. Sce hove and Thunder-storms.

Weather-breeders, 84, 85.

Weather-wisdom, 84-87.

Wheat, 4.

Whip-poor-will (Antrostomus vocis. erus), mother, eggs, and young, $40-42$; an awkward walker, 41,42 ; nest of, 40.

White, Gilbert, 130, 133.

Whitethroat, 134 ; notes of, 132

Whitman, Walt, quotution frum, 71 .

Wilson, Alexauder, quotation from, 42.

Woodchuck, or marmot (Arctomys monax), 42, 179; hole of, 177 , 179.

Wood-grouse, 134.

Wood pecker, downy (Dryobates pus. bescens), 48.

Woodpecker, golden-shafted. See High-hole.

Woodpecker, yellow-bellied, or yellow-bellied sapsucker (Sphyrapicus varius), 167.

Wordsworth, Willism, quotatlona from, 128, 157; the poet of the mountains, $15 \mathrm{~S}$.

Wren, European, song of, 130.

Wren, winter (Troglodyles hiema. lis), 165.

Wrens, songs of, 180. 



North Carolina State University

QH81.B946

LOCUSTS AND

IIS AND WILD HONEY

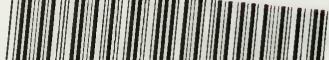

III IIIIII III IIII | || | | | | || S02775195 